\title{
ANÁLISE DA EFICIENNCIA DOS SISTEMAS DE DISTRIBUIÇÃO DE FLORES E PLANTAS ORNAMENTAIS \\ NO ESTADO DE SÃO PAULO
}

\section{JULIANA NEGRINI SMORIGO}

Engenheiro Agrônomo

Orientador: Prof. Dr. Marcos Sawaya Jank

Dissertação apresentada à Escola Superior de Agricultura "Luiz de Queiroz", Universidade de São Paulo, para obtenção do título de Mestre em Ciências, Área de Concentração: Economia Aplicada.

P I R A C I C A B A

Estado de São Paulo - Brasil

Abril $\approx 2000$ 
Dados Internacionais de Catalogação na Publicação (CIP) DIVISĀO DE BIBLIOTECA E DOCUMENTAÇĀO - Campus "Luiz de Queiroz"/USP

Smorigo, Juliana Negrini

Análise da eficiência dos sistemas de distribuição de flores e plantas ornamentais no Estado de São Paulo / Juliana Negrini Smorigo. - - Piracicaba, 2000.

$132 \mathrm{p}$.

Dissertação (mestrado) - Escola Superior de Agricultura Luiz de Queiroz, 2000. Bibliografia.

1. Economia agricola 2. Flor 3. Mercado atacadista 4. Planta ornamental 5. Produtor rural I. Título

CDD 338.1759

Permitida a copia total ou parcial deste documento, desde que citada a fonte- 0 autor" 
Dedico este trabalho à memória de minha mãe, Luiza .

Pelo amor e carinho. 


\section{AGRADECIMENTOS}

Agradeço, inicialmente, ao meu orientador Prof. Dr. Marcos Sawaya Jank, que ao longo dos últimos cinco anos, contribuiu à minha formação como profissional e como pessoa.

Aos professores Dr. José Vicente Caixeta Filho e Dr. Marcos Fava Neves, pelas críticas e sugestões imprescindiveis no desenvolvimento deste trabalho.

Aos professores e funcionários do Departamento de Economia, Administração e Sociologia Rural da ESALQ, pelos conhecimentos transmitidos e pelo auxilio dispensado. À Ligiana, pela gentileza de conferir a normatização das citações de literatura.

À CAPES pelo apoio financeiro dado ao longo do meu programa de mestrado.

À todos os colegas do Curso de Economia Aplicada da ESALQ, pelo convívio durante a realização do mestrado.

Ao Eng. Agr. Marcelo Saito, por me ensinar um pouco mais sobre as flores e pelo auxílio na aplicação dos questionários.

À CEAGESP, CEASA Campinas, Veiling Holambra e FLORANET e seus funcionários, pelo fornecimento dos dados usados nesta pesquisa, em especial à Fernanda Hattnher e Manoel de Oliveira, cuja ajuda foi essencial para realização deste trabalho.

Às amigas Arra e Cumbs, pela amizade e apoio constante durante essa caminhada.

À minha família, pelo incentivo para vencer mais uma etapa da vida, em especial ao Jorge, meu pai, pelos valorosos conselhos e constante apoio na realização de todos os meus sonhos.

Ao Di, um agradecimento especial, pela paciência e carinho nos momentos mais dificeis

À todos aqueles que, de alguma forma, contribuíram com a realização deste trabalho. 


\section{SUMÁRIO}

Página

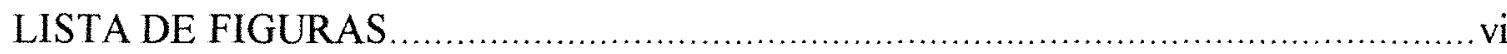

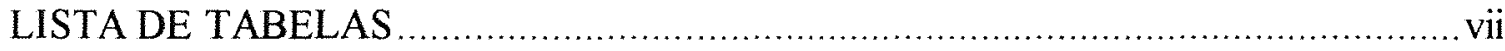

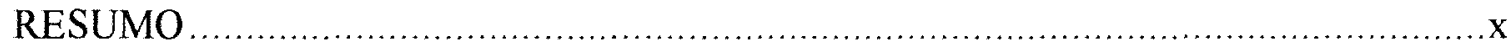

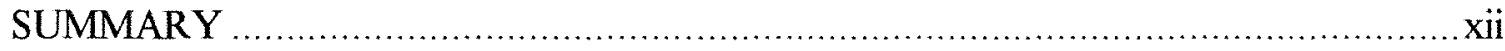

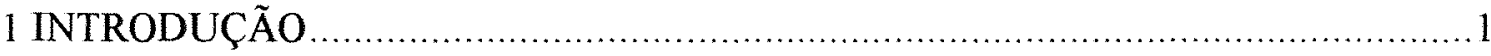

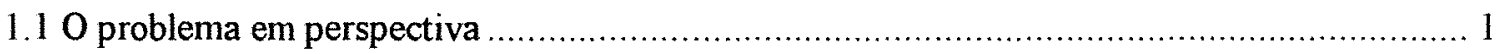

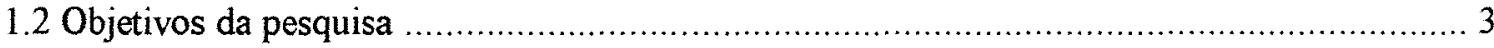

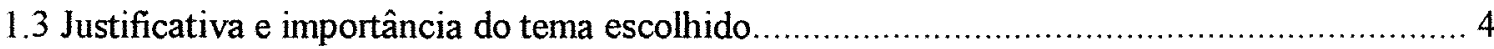

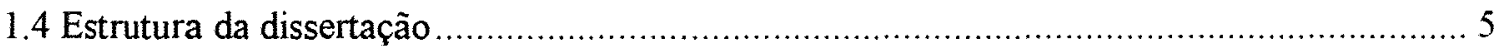

2 O SISTEMA AGROINDUSTRIAL DAS FLORES E PLANTAS

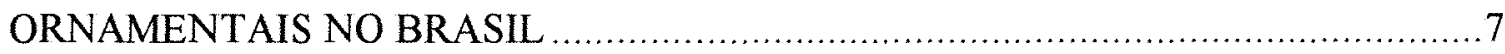

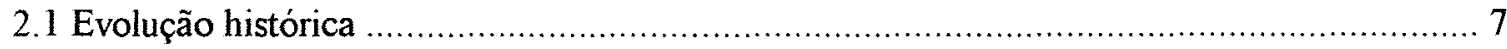

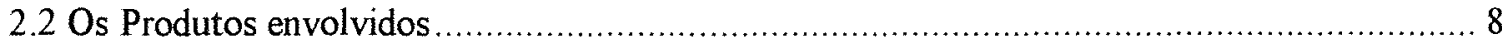

2.3 Descrição e análise dos participantes do Sistema Agroindustrial das Flores e Plantas

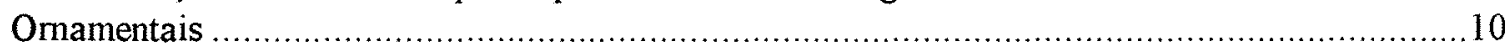

2.3.1 O consumo final de flores e plantas ornamentais................................................................. 11

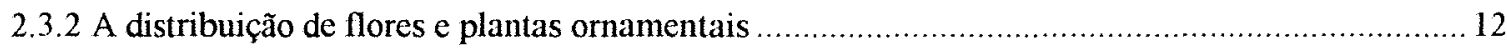

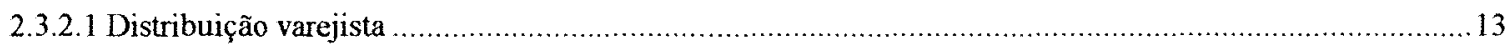

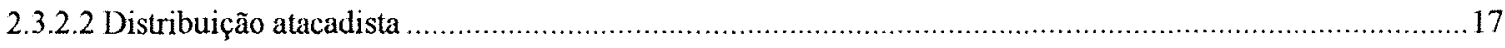

2.3.2.2.1 Sistema de distribuição atacadista público tradicional (SPT1) …................................................19

2.3.2.2.2 Sistema de distribuição atacadista público tradicional com um mercado permanente de flores $e$

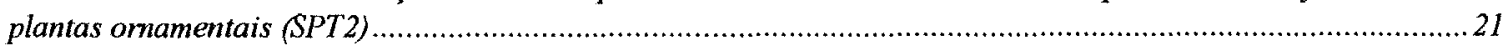

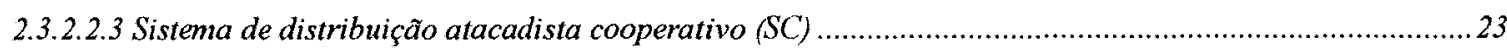

2.3.2.2.4 Sistema de distribuição atacadista privado (SPR) ......................................................................27

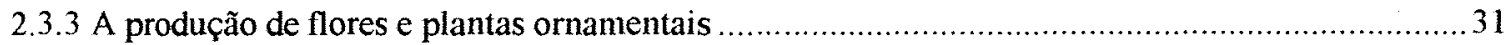

2.3.3.1 Exportação e importação de flores e plantas ornamentais no Brasil ................................................33

2.3.4 Os insumos para produção de flores e plantas ornamentais ........................................35

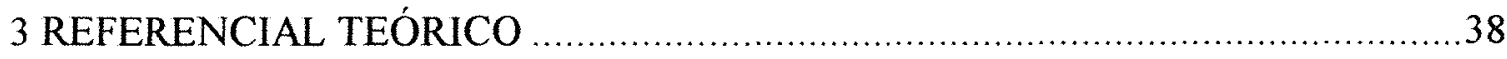

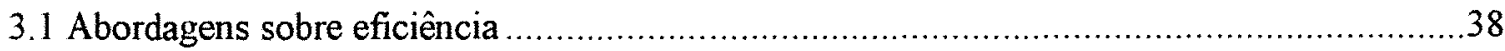

3.20 ambiente institucional e a economia dos custos de transação ...................................47

3.2.1 Aplicações da ECT na análise de sistemas agroindustriais ......................................................54 


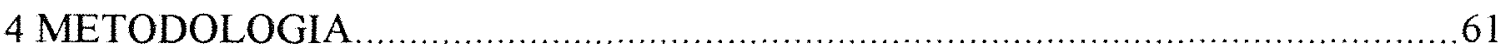

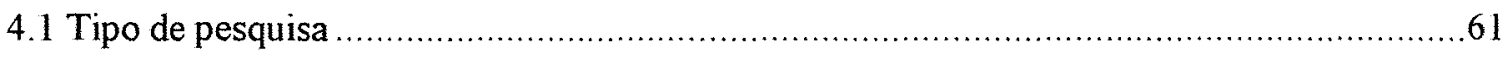

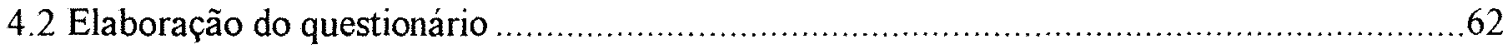

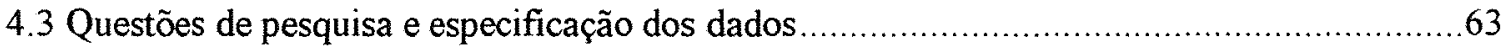

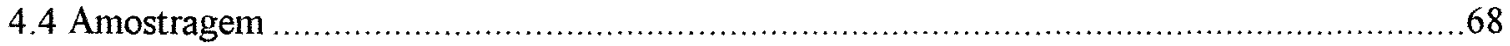

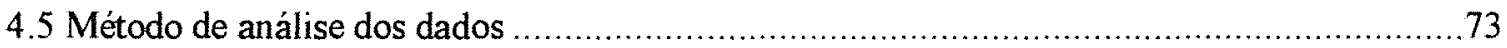

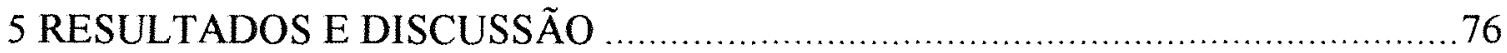

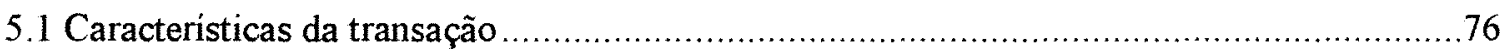

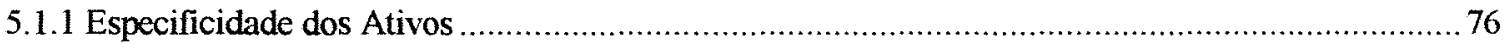

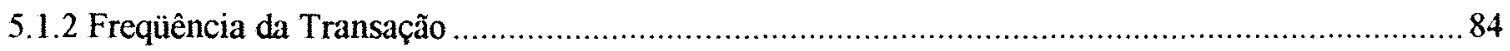

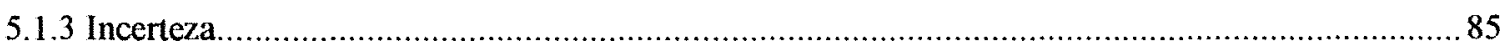

5.2 Estruturas de governança esperadas nas transações entre produtores e sistemas de

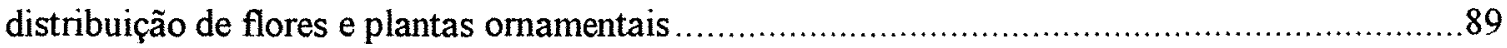

5.3 Aspectos de eficiência e ineficiência dos sistemas de distribuição de flores e plantas

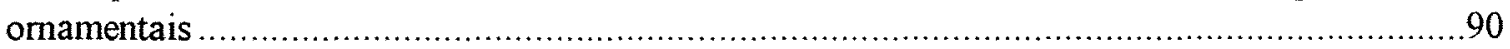

5.3.1 Vantagens e desvantagens dos sistemas de distribuição avaliadas pelos produtores .....................99

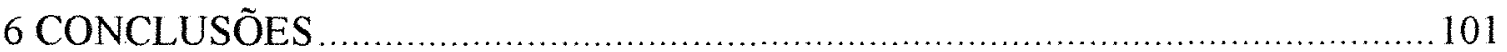

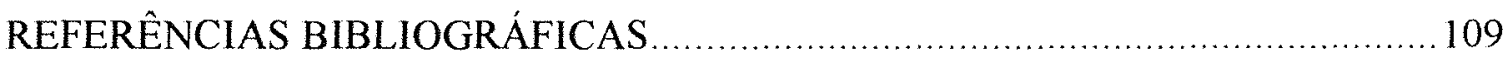

APÊNDICE 1: TABELAS DE RESULTADOS .......................................... 117

APÊNDICE 2: QUESTIONÁRIO DE PESQUISA ....................................... 128 


\section{LISTA DE FIGURAS}

Página

1 Sistema Agroindustrial das Flores e Plantas Ornamentais. ............................ 10

2 Consumo per capita de flores e plantas ornamentais nos paises europeus. ............ 12

3 Diferentes formas de distribuição varejista e atacadista de flores e plantas ornamentais.

4 Participação dos canais de distribuição varejista de flores e plantas ornamentais sobre o total comercializado no Brasil.

5 Participação do Estado de São Paulo no mercado nacional de flores e plantas ornamentais.

6 Participação de quatro sistemas de distribuição atacadista do Estado de São Paulo sobre o faturamento total acumulado de janeiro a outubro de 1999. 18

7 Curva de possibilidade de produção 40

8 Relação entre alternativas de governança. 53

9 Transporte do produto realizado em caminhão refrigerado. 78

10 Satisfação do consumidor em relação à qualidade do produto. 96 


\section{LISTA DE TABELAS}

Página

1 Descrição dos grupos comerciais de flores e plantas ornamentais ............................9

2 Divisão do mercado por faturamento em produtos no Brasil, 1995-1998 …............15

3 Tabela comparativa em termos de volume nas regiões ........................................17

4 Atividades dos compradores no pavilhão do MLP e Praça da Batata ........................20

5 Área cultivada e procedência dos produtores associados ao CEASA Campinas........22

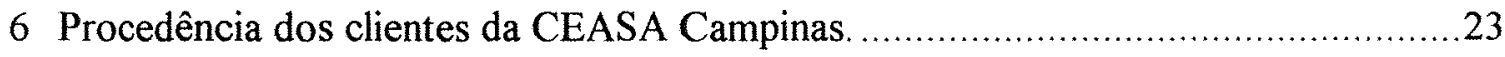

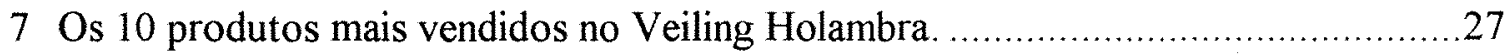

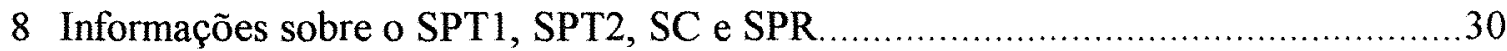

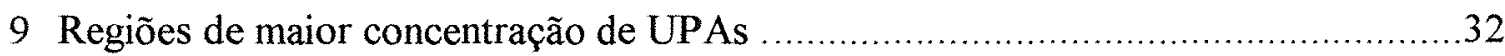

10 Categorias de flores com maior número de áreas homogêneas (AHs) ......................32

11 Importações e exportações brasileiras de plantas vivas e produtos de

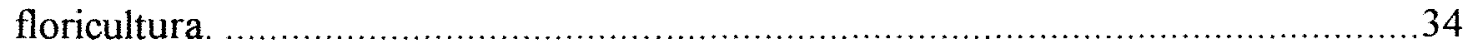

12 Valor da importação e exportação de flores no Brasil por categoria.........................35

13 Questões relacionadas as características das transações........................................67

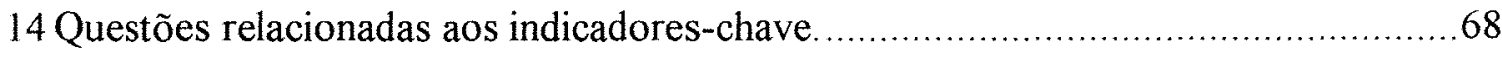

15 Tamanho da população, tamanho mínimo da amostra, nível de confiabilidade e

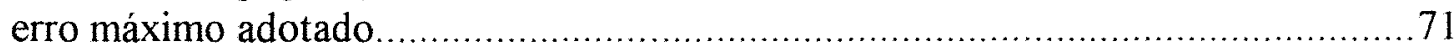

16 Tamanho da população e da amostra entrevistada, erro e nivel de confiabilidade... .72

17 Utilização de sistema coberto de produção pelos produtores.................................77

18 Tipo de sistema coberto de produção utilizado pelos produtores ...........................77

19 Origem das mudas e sementes utilizadas pelos produtores. ..................................77

20 Investimento na marca do produto pelos produtores. .......................................... 80

21 Forma de investimento na marca do produto pelos produtores ............................... 80

22 Forma de capital humano responsável pela assistência técnica na produção ..............81

23 Treinamento especializado dos funcionários para a produção flores e plantas

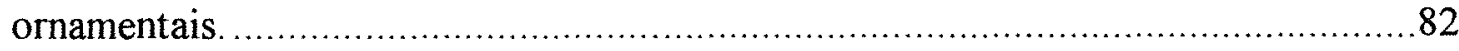

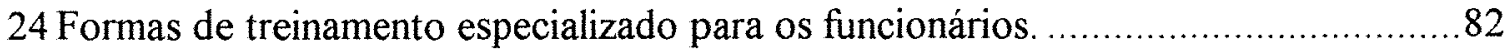

25 Facilidade de substituição dos funcionários utilizados na produção. ........................82 
26 Classificação dos principais tipos de especificidades relacionadas ao ativo flor

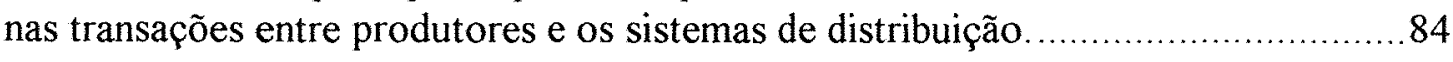

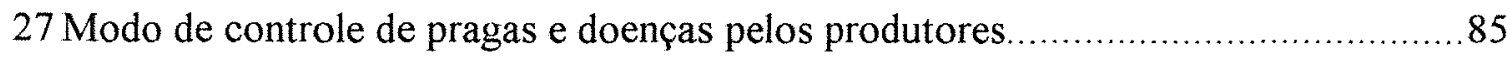

28 Frequência para os produtores que realizam o controle seqüencial. .........................86

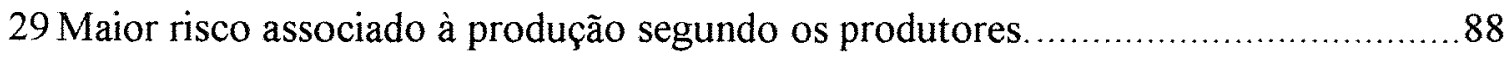

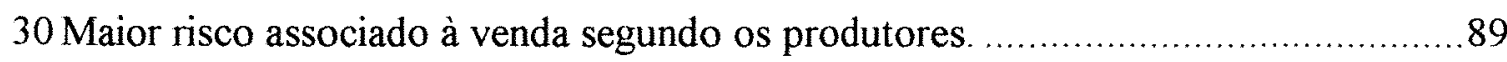

31 Faturamento do sistema de distribuição por tempo de comercialização......................91

32 Faturamento do sistema de distribuição por hora-homem trabalhada ......................92

33 Tempo de ociosidade por homem no período de um dia .......................................93

34Faturamento do sistema de distribuição por área total utilizada para a

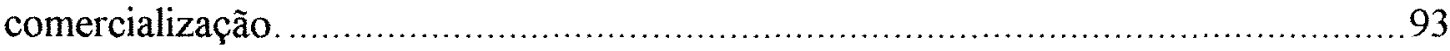

35 Quantidade de vezes em que se manuseia o produto. ........................................94

36 Preço pago pelo produto é coerente com a sua qualidade .....................................97

$37 \mathrm{O}$ motivo da incoerência entre preço e qualidade. ..............................................97

38 Tempo gasto com o carregamento pelo consumidor. ............................................99

39 Resumo dos principais motivos, vantagens e desvantagens da utilização dos sistemas de distribuição pelos produtores..................................................... 100

40 Resumo dos resultados dos indicadores-chave para os sistemas de distribuição. ..... 104

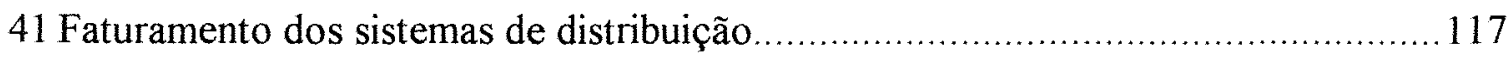

42 Dias de funcionamento dos sistemas de distribuição ............................................. 117

43 Tempo gasto com a comercialização por dia e semana ........................................118

44 Tempo gasto com a comercialização no periodo de janeiro a outubro de 1999 ......118

45 Número de homens envolvidos por dia de comercialização. .................................118

46 Tempo de trabalho por homem no período de um dia. ........................................119

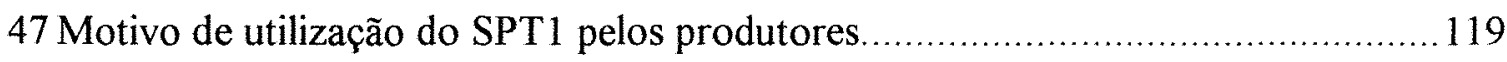

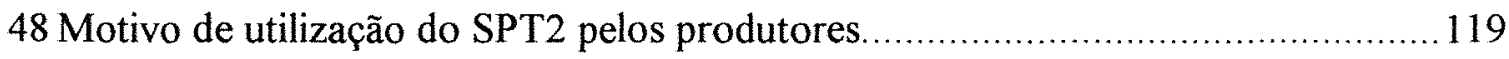

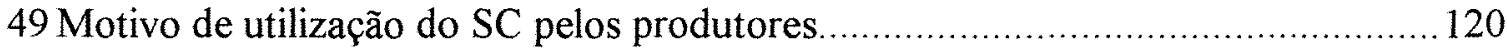

50 Motivo de utilização do SPR pelos produtores. ................................................ 120

51 Vantagem avaliada pelos produtores em utilizar o SPT1 ................................ 120

52 Vantagem avaliada pelos produtores em utilizar o SPT2 …............................. 121

53 Vantagem avaliada pelos produtores em utilizar o SC ..................................... 121

54 Vantagem avaliada pelos produtores em utilizar o SPR ..................................... 121 
55 Desvantagem avaliada pelos produtores em utilizar o SPT1

56 Desvantagem avaliada pelos produtores em utilizar o SPT2

57 Desvantagem avaliada pelos produtores em utilizar o SC

58 Desvantagem avaliada pelos produtores em utilizar o SPR

59 Motivo de utilização do SPT1 pelos consumidores

60 Motivo de utilização do SPT2 pelos consumidores. 124

61 Motivo de utilização do SC pelos consumidores.

62 Motivo de utilização do SPR pelos consumidores. 124

63 Outros problemas apresentados no sistema de distribuição - consumidor SPT1

64 Outros problemas apresentados no sistema de distribuição - consumidor SPT2 ..... 126

65 Outros problemas apresentados no sistema de distribuição - consumidor SC. 126

66 Outros problemas apresentados no sistema de distribuição - consumidor SPR

67 Resultados de algumas análises estatísticas relativas as questões com variáveis quantitativas. 


\title{
ANÁLISE DA EFICIÊNCIA DOS SISTEMAS DE DISTRIBUIÇÃO DE FLORES E PLANTAS ORNAMENTAIS NO ESTADO DE SÃo PAUlO
}

\author{
Autora: JULIANA NEGRINI SMORIGO \\ Orientador: Prof. Dr. MARCOS SAWAYA JANK
}

\section{RESUMO}

O presente trabalho analisou as condições que caracterizam as transações existentes entre produtores e sistemas de distribuição atacadista de flores e plantas ornamentais do Estado de São Paulo, utilizando o referencial teórico da Economia dos Custos de Transação e identificando as estruturas de governança que prevalecem. Também, foram sinalizados aspectos de eficiência e ineficiência desses sistemas de distribuição, determinados através de indicadores-chave.

Foram avaliadas quatro categorias distintas de sistemas de distribuição atacadista: um público tradicional (SPT1), um público tradicional com um mercado permanente de flores e plantas ornamentais (SPT2), um cooperativo (SC) e um privado (SPR), representados respectivamente pela CEAGESP, CEASA Campinas, Veiling Holambra e a empresa FLORANET.

O estudo foi realizado através de questionários aplicados aos produtores, funcionários dos sistemas de distribuição e consumidores de flores e plantas ornamentais. Para o dimensionamento do tamanho da amostra foi utilizada a técnica amostral probabilística aleatória simples. A análise dos dados foi fundamentada utilizando-se a técnica de estatistica descritiva.

Os resultados obtidos permitem concluir que a estrutura de governança via mercado foi a resultante nas transações existentes entre produtores e o SPT1 e o SPT2, 
decorrente da baixa especificidade dos ativos fisicos, marca e humana. A estrutura de governança híbrida foi a resultante nas transações existentes entre produtores e o SC e o SPR, visto que essas especificidades dos ativos aumentaram.

Através dos resultados dos indicadores-chave, foi possível identificar para cada sistema de distribuição atacadista quais aspectos sinalizados neste trabalho deverão ser melhorados, visando elevar a sua eficiência, e consequentemente, aumentar sua competitividade no setor. 


\title{
EFFICIENCY ANALYSIS OF THE DISTRIBUTION SYSTEMS OF FLOWERS AND ORNAMENTAL PLANTS IN THE STATE OF SÃo PAULO
}

\author{
Author: JULIANA NEGRINI SMORIGO \\ Adviser: Prof. Dr. MARCOS SAWAYA JANK
}

\section{SUMMARY}

The present work analyzed the conditions characterizing the existent transactions among producers and wholesaler distribution systems of flowers and ornamental plants of the State of São Paulo. The theoretical referencial of the Transaction Cost Economics was used, identifying the governance structures that prevail. Efficiency and inefficiency aspects of those distribution systems through key-indicators were also shown.

Four different categories of wholesaler distribution systems were evaluated: a traditional public (SPT1), a traditional public with a permanent market of flowers and ornamental plants (SPT2), a cooperative (SC) and a private (SPR), represented respectively by CEAGESP, CEASA Campinas, Veiling Holambra and FLORANET company.

The study was accomplished through questionnaires applied to the producers, employees of the distribution systems and consumers of flowers and ornamental plants. The sample size was determined using a simple random probability technique. The data analysis was based on the descriptive statistics technique.

The results showed that the governance structure through market was the resultant of the existent transactions among producers and the SPT1 and SPT2, due to the low physical, brand and human asset specificity. The hybrid governance structure was 
the resultant of the existent transactions among producers and the SC and SPR, because those asset specificity increased.

Through the results of the key-indicators, it was possible to identify for each wholesaler distribution systems which aspects signalled in that work should improve to elevate its efficiency and, consequently, increase its competitiveness in the sector. 


\section{INTRODUÇÃO}

\subsection{0 problema em perspectiva}

O setor de flores e plantas ornamentais abrange uma grande diversidade de produtos, como o cultivo e a exploração econômica de plantas ornamentais, flores de corte frescas ou secas, plantas em vaso, folhagens frescas ou desidratadas, estacas, enxertos, alporques, substratos de enraizamento e condução de mudas, produção de arbustos e árvores de grande porte.

A floricultura destaca-se por ser uma atividade de alta rentabilidade por área e intensiva em mão-de-obra, que pode contribuir para a diminuição do êxodo rural e o aproveitamento dos minifúndios. Outra característica relevante é a sua contribuição para o orçamento doméstico da pequena propriedade.

O Brasil tem apresentado aumento no volume de movimentação financeira e da demanda interna e exportada nos últimos anos. A avaliação global do mercado indica que o consumo potencial é muito grande. No entanto, o sistema agroindustrial como um todo necessita de maior organização. A falta de integração entre os agentes do sistema limita o desenvolvimento da atividade.

Compreender esse sistema agroindustrial, analisando as relações existentes entre os agentes que o compõe e propondo melhorias, torna-se necessário para organização e, consequentemente, a competitividade desse setor. 
Entre os diversos segmentos da cadeia produtiva, o de distribuição merece destaque, pois é o elo que aproxima os produtores do consumidor final, efetuando a negociação de transações de troca.

O setor de distribuição de flores e plantas ornamentais no Brasil é composto por atacadistas e varejistas, sendo a distribuição atacadista realizada através de diversos sistemas, como os centros atacadistas públicos e privados.

Por muitos anos, a distribuição de flores e plantas ornamentais no Brasil foi realizada por centros atacadistas, que se desenvolveram com uma série de falhas. A oferta de flores e plantas ornamentais, quantitativamente crescente e qualitativamente indiferenciada, superou qualquer preocupação com o desenvolvimento da qualidade dos produtos e serviços oferecidos, o aperfeiçoamento técnico e profissional dos agentes envolvidos no processo - produtores e distribuidores atacadistas. Esses agentes mantiveram atitudes tradicionais, enfocando somente os efeitos imediatos da comercialização, desprezando as necessidades do consumidor.

Esse quadro não chegou a inviabilizar a sobrevivência dos centros atacadistas tradicionais. No entanto, aumentou a competição pelo mercado, com o surgimento de sistemas de distribuição preocupados com a implantação de estruturas logísticas e operacionais mais modernas, dispostos a atender consumidores cada vez mais exigentes.

Atualmente, na floricultura paulista, responsável por cerca de $60 \%$ do mercado nacional, são encontrados os principais sistemas de distribuição atacadista, os quais foram surgindo com o desenvolvimento do setor.

Em 1969, foi inaugurado o Mercado de Flores na Companhia de Entrepostos e Armazéns Gerais de São Paulo (CEAGESP), caracterizado como sistema atacadista público tradicional. Em 1989 foi instalado o Veiling Holambra, caracterizado como sistema atacadista cooperativo. Já em agosto de 1993 foi fundada a CEASA Campinas, a única Central de Abastecimento a ter um mercado permanente de flores e plantas ornamentais, caracterizada como sistema atacadista público tradicional com um mercado permanente. Mais recentemente, em novembro de 1998, na cidade de Holambra - SP, foi inaugurada a empresa FLORANET, caracterizada como sistema atacadista privado. 
O problema básico da pesquisa deste trabalho está em identificar as diferenças nas condições que caracterizam as transações existentes entre produtores e cada sistema de distribuição. Essas diferenças acabam por determinar estruturas de governança distintas. Além disso, os atuais sistemas de distribuição possuem diferenças com o investimento de estrutura fisica e custeio do funcionamento, tempo de comercialização, número de funcionários envolvidos, satisfação do consumidor, entre outras, que devem levá-los a apresentar diferentes indices de eficiência. Sistemas de distribuição que apresentam aspectos de ineficiência agregam custos maiores, que acabam onerando o produtor e o consumidor.

\subsection{Objetivos da pesquisa}

O estudo analisará as condições que caracterizam as transações existentes entre produtores e sistemas de distribuição atacadista de flores e plantas ornamentais do Estado de São Paulo, sob o enfoque da Economia dos Custos de Transação, identificando as estruturas de governança que prevalecem.

Serão analisadas quatro categorias distintas de sistemas de distribuição: um público tradicional (SPT1), um público tradicional com um mercado permanente de flores e plantas ornamentais (SPT2), um cooperativo (SC) e um privado (SPR), representados respectivamente pela CEAGESP, CEASA Campinas, Veiling Holambra e a empresa FLORANET.

Também serão sinalizados aspectos de eficiência e ineficiência desses sistemas de distribuição, determinados através de indicadores-chave, como o faturamento do sistema de distribuição por tempo de comercialização, faturamento por hora-homem trabalhada, tempo de ociosidade por homem, faturamento por área total, contribuição do sistema de distribuição na manutenção da qualidade do produto, grau de satisfação do consumidor e tempo de carregamento gasto pelo consumidor no sistema de distribuição. 
Para compreender a importância desta análise, em primeiro lugar, será caracterizado o Sistema Agroindustrial das Flores e Plantas Ornamentais (SAG) no Brasil, identificando atores e a dinâmica das relações praticadas pelos agentes do sistema. O foco da caracterização será os quatro sistemas de distribuição atacadista.

\subsection{Justificativa e importância do tema escolhido}

O mercado de flores e plantas ornamentais brasileiro movimentou em 1995 um valor estimado de US\$ 700 milhões no varejo, passando para US\$1,3 bilhão em 1998 (Kiyuna, 1998). O consumo que era $\mathrm{R} \$ 3,00$ per capita/ano no início da década de 90 subiu para R\$7,00 per capita em 1997 (Silveira, 1997). Esse crescimento do mercado em termos de faturamento e o aumento do consumo per capita de flores e plantas ornamentais levaram ao surgimento de diversos sistemas de distribuição.

A sobrevivência dos sistemas de distribuição de flores e plantas ornamentais no Brasil está vinculada à otimização de processos de produção e gerenciais, demonstrando a importância em entender a dinâmica das relações entre produtores e cada um desses sistemas, identificando as estruturas de governança que prevalecem.

Além disso, através dos resultados dos indicadores-chave determinados neste trabalho, será possivel aos sistemas de distribuição analisar em quais aspectos está sendo ineficiente e buscar operar com elevados índices de eficiência, conduzindo a uma economia substancial de recursos e atingindo os padrões e preferências desejados pelos consumidores.

Quanto à originalidade, o trabalho procurou caracterizar o Sistema Agroindustrial das Flores e Plantas Ornamentais, focando as transações existentes entre produtores e quatro sistemas de distribuição de flores e plantas ornamentais do Estado de São Paulo, utilizando o referencial teórico da Economia dos Custos de Transação.

Os trabalhos de Aki (1998), Kiyuna (1998), Arruda et al. (1996) e Rooyen \& Optiz (1997) contribuíram para a caracterização do Sistema Agroindustrial das Flores e 
Plantas Ornamentais no Brasil e o trabalho de Claro (1998) contribuiu para essa caracterização perante a ótica da Economia dos Custos de Transação. O trabalho de Claro (1998) analisou apenas dois sistemas de distribuição: Veiling Holambra e CEASA Campinas.

No presente trabalho serão avaliados mais dois sistemas de distribuição do Estado de São Paulo: CEAGESP e FLORANET. Este trabalho é inédito ao sinalizar aspectos de eficiência e ineficiência dos sistemas de distribuição CEAGESP, CEASA Campinas, Veiling e FLORANET.

\subsection{Estrutura da dissertação}

O presente capítulo 1 traz uma breve introdução, apresentando o problema em perspectiva e os objetivos da pesquisa. Ainda neste capítulo, estão apresentadas as justificativas e importância do tema escolhido.

O capítulo 2 apresenta uma revisão de literatura sobre o Sistema Agroindustrial das Flores e Plantas Ornamentais no Brasil, especificando quatro sistemas de distribuição atacadista do Estado de São Paulo, que serão foco de análise do presente trabalho.

O capítulo 3 apresenta o referencial teórico, expondo abordagens sobre eficiência e o ambiente institucional e a Economia dos Custos de Transação. Neste capítulo é mostrado como a eficiência é tratada na literatura e o surgimento da Economia dos Custos de Transação e seus pressupostos básicos. Também são apresentadas algumas aplicações da Economia dos Custos de Transação na análise de sistemas agroindustriais.

O capítulo 4 descreve a metodologia empregada nesta dissertação, apresentando o tipo de pesquisa, a forma de elaboração do questionário, as questões de pesquisa e especificação dos dados, a técnica amostral utilizada e o método de análise dos dados.

No capítulo 5 estão demonstrados os resultados e discussões, descrevendo as características das transações entre produtores e sistemas de distribuição e as estruturas de governança resultantes. Ainda neste capítulo, estão sinalizados os aspectos de 
eficiência e ineficiência dos sistemas de distribuição e as vantagens e desvantagens em utilizá-los.

O capítulo 6 apresenta as conclusões finais da dissertação, mostrando algumas tendências para o Sistema Agroindustrial das Flores e Plantas Ornamentais e considerações para futuros trabalhos. 


\section{O SISTEMA AGROINDUSTRIAL DAS FLORES E PLANTAS ORNAMENTAIS NO BRASIL}

\subsection{Evolução histórica}

A produção comercial de flores e plantas ornamentais foi implantada no Brasil na década de 30 , quando imigrantes japoneses se estabeleceram na região do cinturão verde da capital paulista, fornecendo inicialmente produtos apenas para consumidores da Grande São Paulo (Smorigo, 1997).

Segundo Góes (1997), no início dos anos 50, a colônia portuguesa fixou-se na região de Guarulhos - SP e iniciou a produção de flores. Em meados dos anos 60, imigrantes holandeses trouxeram novas técnicas de produção para a região do interior do Estado de São Paulo (Smorigo, 1997).

Um grande impulso no setor ocorreu no final da década de 70, quando um novo grupo de holandeses chegou ao Brasil, trazendo o conhecimento das técnicas de produção em estufa e diversas novas espécies de plantas.

A CEAGESP passou a ser o principal centro de distribuição de flores e plantas ornamentais do país a partir deste período. Em 1989 iniciou-se o sistema de distribuição do Veiling Holambra, baseado na oferta e demanda diária de produtos e em 1993 foi inaugurado o Mercado Permanente de Plantas e Flores na CEASA Campinas.

- Em novembro de 1998, foi inaugurado o sistema de distribuição FLORANET, a primeira experiência de comercialização eletrônica virtual de flores e plantas através da internet, organizando os fluxos de informações entre as diversas regiões produtoras e o centro de consumo através dos atacadistas/distribuidores. 


\subsection{Os Produtos envolvidos}

As flores e plantas ornamentais podem ser classificadas em grupos comerciais, tais como flores de corte e vaso, plantas de interior e paisagismo, flores e plantas tropicais e folhagens.

As flores de corte podem ser divididas ainda em 2 outros subgrupos: aquelas mais usadas em floriculturas (como as rosas e os crisântemos de corte) e aquelas usadas em decoração (como as gérberas e os lírios). As rosas são os produtos mais tradicionais do mercado (Aki, 1998). Quanto as flores em vaso, as mais comercializadas são as violetas, crisântemos de vaso e azaléias.

Já as plantas de interior tiveram grande crescimento nos últimos anos devido à entrada de novos produtores no mercado. O aumento da oferta reduziu os preços. As plantas de paisagismo foram as grandes privilegiadas com as mudanças verificadas nos sistemas de distribuição. Até a época onde a maior parte da distribuição era realizada por atacadistas, era muito dificil comercializar o produto via caminhão do atacadista, devido principalmente ao espaço ocupado pelo produto. Com a inauguração dos centros atacadistas em todos os principais estados consumidores, o produto achou seu espaço e teve sua distribuição melhorada. A dificuldade de padronização é seu principal desafio para uma nova evolução.

As flores e plantas tropicais são usadas basicamente em decoração. A produção é realizada por todo litoral do país. A venda é realizada informalmente e muitas vezes diretamente entre o produtor e o consumidor final. Já as folhagens, podem ser produtos produzidos especificamente para este fim (como a gypsofila ou mosquitinho, avencão, etc) ou tirados a partir de arvoredos e arbustos (tuias, ciprestes, dracenas, etc).

A Tabela 1 apresenta os grupos comerciais, com seus principais produtos e suas características. 
Tabela 1. Descrição dos grupos comerciais de flores e plantas ornamentais.

\begin{tabular}{|c|c|c|}
\hline $\begin{array}{l}\text { Grupos } \\
\text { Comerciais }\end{array}$ & $\begin{array}{l}\text { Nome comum } \\
\text { (Gênero) }\end{array}$ & Principais Características \\
\hline \multirow{5}{*}{$\begin{array}{l}\text { Flores de } \\
\text { corte }\end{array}$} & $\begin{array}{l}\text { Rosa } \\
(\text { Rosa })\end{array}$ & $\begin{array}{l}\text { - Florífera mais apreciada em todo mundo, planta perene e } \\
\text { colheita diária, durante o ano todo. }\end{array}$ \\
\hline & $\begin{array}{l}\text { Crisântemo } \\
\text { (Chrysanthemum) }\end{array}$ & $\begin{array}{l}\text { - Considerada a flor nacional do Japão, grande diversidade de } \\
\text { tipos e cores de flores e produção em qualquer época do ano. }\end{array}$ \\
\hline & $\begin{array}{l}\text { Lírio } \\
(\text { Lilium })\end{array}$ & $\begin{array}{l}\text { - Estão entre as mais belas plantas de bulbos, flores de inúmeras } \\
\text { cores e florescimento da primavera ao outono. }\end{array}$ \\
\hline & $\begin{array}{l}\text { Cravo } \\
\text { (Dianthus) }\end{array}$ & $\begin{array}{l}\text { - Originária da região mediterrânea, planta herbácea e cultivada } \\
\text { em localidades de altitudes elevadas. }\end{array}$ \\
\hline & $\begin{array}{l}\text { Gladíolo } \\
\text { (Gladiolus) }\end{array}$ & $\begin{array}{l}\text { - Uma das mais populares flores do mundo, são conhecidas acima } \\
\text { de } 150 \text { espécies e floresce o ano todo. }\end{array}$ \\
\hline \multirow{5}{*}{$\begin{array}{l}\text { Flores de } \\
\text { vaso }\end{array}$} & $\begin{array}{l}\text { Crisântemo } \\
\text { (Chrysanthemum) }\end{array}$ & $\begin{array}{l}\text { - Excelente durabilidade em vaso, necessita de muita luz e um } \\
\text { solo sempre úmido. }\end{array}$ \\
\hline & $\begin{array}{l}\text { Violeta } \\
\text { (Saintpaulia) }\end{array}$ & $\begin{array}{l}\text { - Planta de clima quente, variedade imensa de hibridos, } \\
\text { cultivadas em estufas e multiplicação por mudas. }\end{array}$ \\
\hline & $\begin{array}{l}\text { Antúrio } \\
\text { (Anthurium) }\end{array}$ & $\begin{array}{l}\text { - Cultivo fácil, principalmente nas regiões quentes e úmidas, } \\
\text { plantas obtidas através de sementes e plantio o ano todo. }\end{array}$ \\
\hline & $\begin{array}{l}\text { Azaléia } \\
\text { (Rhododendron) }\end{array}$ & $\begin{array}{l}\text { - Porte arbustivo, floresce no inverno, após sofrer um choque } \\
\text { térmico e propagadas por estacas. }\end{array}$ \\
\hline & $\begin{array}{l}\text { Begônia } \\
\text { (Begonia) }\end{array}$ & $\begin{array}{l}\text { - Espécies tuberosas e florescem principalmente no início da } \\
\text { primavera. }\end{array}$ \\
\hline \multirow{4}{*}{$\begin{array}{l}\text { Plantas de } \\
\text { interior } \\
\text { e paisagismo }\end{array}$} & $\begin{array}{l}\text { Samambaia } \\
\text { (Nephrolepis) }\end{array}$ & $\begin{array}{l}\text { - São sensiveis à baixa temperatura, necessitando de ambiente } \\
\text { aquecidos e cultivadas sob estufas plásticas. }\end{array}$ \\
\hline & $\begin{array}{l}\text { Palmeira } \\
\text { (Chamaedorea) }\end{array}$ & $\begin{array}{l}\text { - Plantas lenhosas com uma coroa de folhas e frequientes nas } \\
\text { regiões úmidas e quentes. }\end{array}$ \\
\hline & $\begin{array}{l}\text { Ficus } \\
\text { (Ficus })\end{array}$ & $\begin{array}{l}\text { - Necessitam de muita luz, podem receber luz direta e se adaptam } \\
\text { tanto em ambientes externos como internos. }\end{array}$ \\
\hline & $\begin{array}{l}\text { Filodendro } \\
\text { (Philodendron) }\end{array}$ & $\begin{array}{l}\text { - Necessitam de um solo sempre úmido e se adaptam tanto em } \\
\text { ambientes externos como internos. }\end{array}$ \\
\hline \multirow{3}{*}{ Folhagens } & $\begin{array}{l}\text { Gipsofila } \\
\text { (Gypsophila) }\end{array}$ & $\begin{array}{l}\text { - Mais conhecida como "Branqinha" ou "Mosquitinho" e pode ser } \\
\text { plantada em qualquer época do ano. }\end{array}$ \\
\hline & $\begin{array}{l}\text { Cipreste } \\
\text { (Cupressus) }\end{array}$ & - Disponibilidade alta do produto em qualquer época do ano. \\
\hline & $\begin{array}{l}\text { Dracena } \\
\text { (Dracaena) }\end{array}$ & $\begin{array}{l}\text { - Plantas herbáceas ou lenhosas e de propagação vegetativa com } \\
\text { época de plantio variando de acordo com a variedade. }\end{array}$ \\
\hline \multirow{3}{*}{$\begin{array}{l}\text { Flores e } \\
\text { plantas } \\
\text { tropicais }\end{array}$} & $\begin{array}{l}\text { Helicônia } \\
\text { (Heliconia) }\end{array}$ & $\begin{array}{l}\text { - Conhecida no Brasil como "Bananeiras de Jardim" e são } \\
\text { plantadas no final do inverno e início da primavera. }\end{array}$ \\
\hline & $\begin{array}{l}\text { Estrelítzia } \\
\text { (Strelitzia) }\end{array}$ & $\begin{array}{l}\text { - Ocorrem naturalmente nas Américas Central e do Sul e são } \\
\text { colhidas as hastes florais ao nivel do solo. }\end{array}$ \\
\hline & $\begin{array}{l}\text { Antúrio } \\
\text { (Anthurium) }\end{array}$ & $\begin{array}{l}\text { - Cultivo fácil nas regiões quentes e úmidas e podem ser } \\
\text { plantadas o ano todo, devendo evitar os meses mais frios. }\end{array}$ \\
\hline
\end{tabular}

Fonte: Elaborado e resumido pelo autor a partir de Castro et al. (1992) 
2.3 Descrição e análise dos participantes do Sistema Agroindustrial das Flores e Plantas Ornamentais

O Sistema Agroindustrial das Flores e Plantas Ornamentais é composto por diversos segmentos da cadeia produtiva como os fornecedores de insumos, os produtores, os distribuidores (atacadistas e varejistas) e os consumidores finais. A Figura 1 mostra os segmentos do Sistema Agroindustrial das Flores e Plantas Ornamentais.

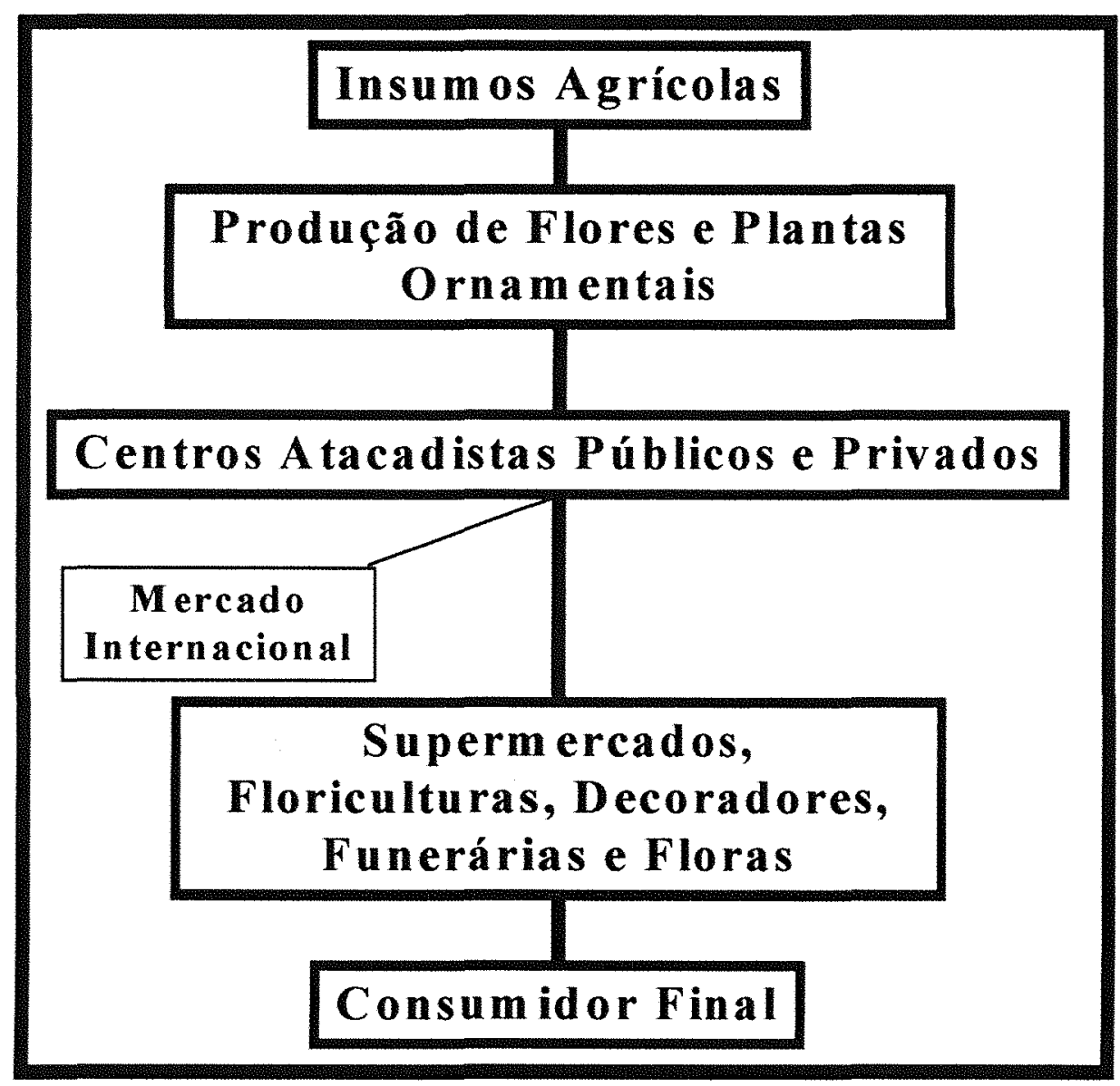

Figura 1 - Sistema Agroindustrial das Flores e Plantas Ornamentais.

A seguir serão descritos os participantes do Sistema Agroindustrial das Flores e Plantas Ornamentais. 


\subsubsection{O consumo final de flores e plantas ornamentais}

O consumo de flores e plantas ornamentais está crescendo no Brasil. Estabilizado no início da década de 90 em $R \$ 3,00$ per capita/ano, o consumo subiu para R \$ 7,00 per capita em 1997 e deverá alcançar os R\$10,00 até a virada do século, segundo estimativas da Cooperativa Agropecuária Holambra (Silveira, 1997).

O consumidor brasileiro, de modo geral, está insatisfeito com a durabilidade dos produtos e desconhece a qualidade. Também tem pouco acesso a informações sobre as características de cada produto (Aki, 1998).

O consumo é concentrado nas datas de pico. No passado, o comércio de flores e plantas ornamentais era bastante forte em datas como o dia das mães, Finados e Natal. Atualmente existem oito datas fortes durante o ano: dia internacional da mulher, dia das mães, dia dos namorados, dia dos avós, dia dos pais, dia da secretária, Finados e Natal.

Apesar do consumo per capita estar crescendo no Brasil, ele ainda é bastante baixo quando comparado a outros países. De acordo com Aimone (1997), os Estados Unidos estão ao lado do Japão como os 2 maiores mercados consumidores de flores e plantas ornamentais do mundo.

Segundo Vieira \& Albertini ${ }^{1}$, no ano de 1996, o consumo per capita nos EUA foi de US\$140,00, a produção doméstica movimentou cerca de 11 bilhões de dólares e as importações movimentaram cerca de 950 milhões de dólares.

Em fevereiro de 1997, a revista Flora Culture International reproduziu um estudo feito pelo Flower Council of Holland que estimou o crescimento do consumo em 21 países europeus (Aki, 1998). A Figura 2 mostra essa projeção de consumo per capita nos paises europeus (valor em dólares).

28: ${ }^{1}$ VIEIRA, D. P., ALBERTINI, M. A. (CEAGESP. Companhia de Entrepostos e Armazéns Gerais de São Paulo, São Paulo). Comunicação Pessoal, 1999. 


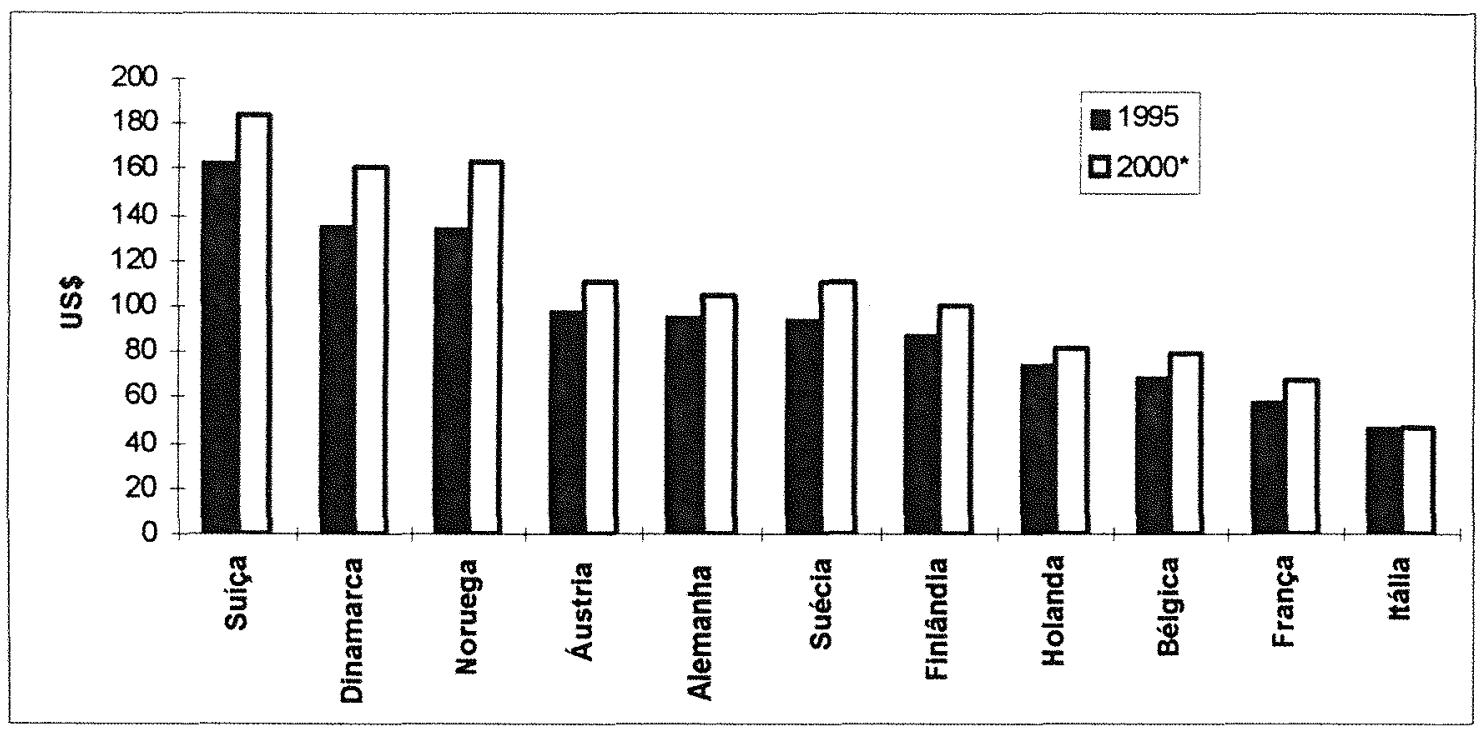

Figura 2 - Consumo per capita de flores e plantas ornamentais nos países europeus.

Fonte: Aki (1998)

\subsubsection{A distribuição de flores e plantas ornamentais}

O setor de distribuição é constituído principalmente de varejo e atacado. Varejo, segundo Stern et al, Berman e Rosembloon, citados por Neves (1999), caracteriza-se por atividades de negócios que vendem produtos e serviços aos consumidores para uso pessoal, familiar ou da casa. Já atividades atacadistas, segundo Stern et al. e Berman, citados por Neves (1999), são definidas como as de estabelecimentos que vendem a varejistas, compradores industriais, institucionais e comerciais, mas não em quantias significantes aos consumidores finais.

A Figura 3 mostra as diferentes formas de distribuição varejistas e atacadistas de flores e plantas ornamentais desde a produção até o consumidor final. 


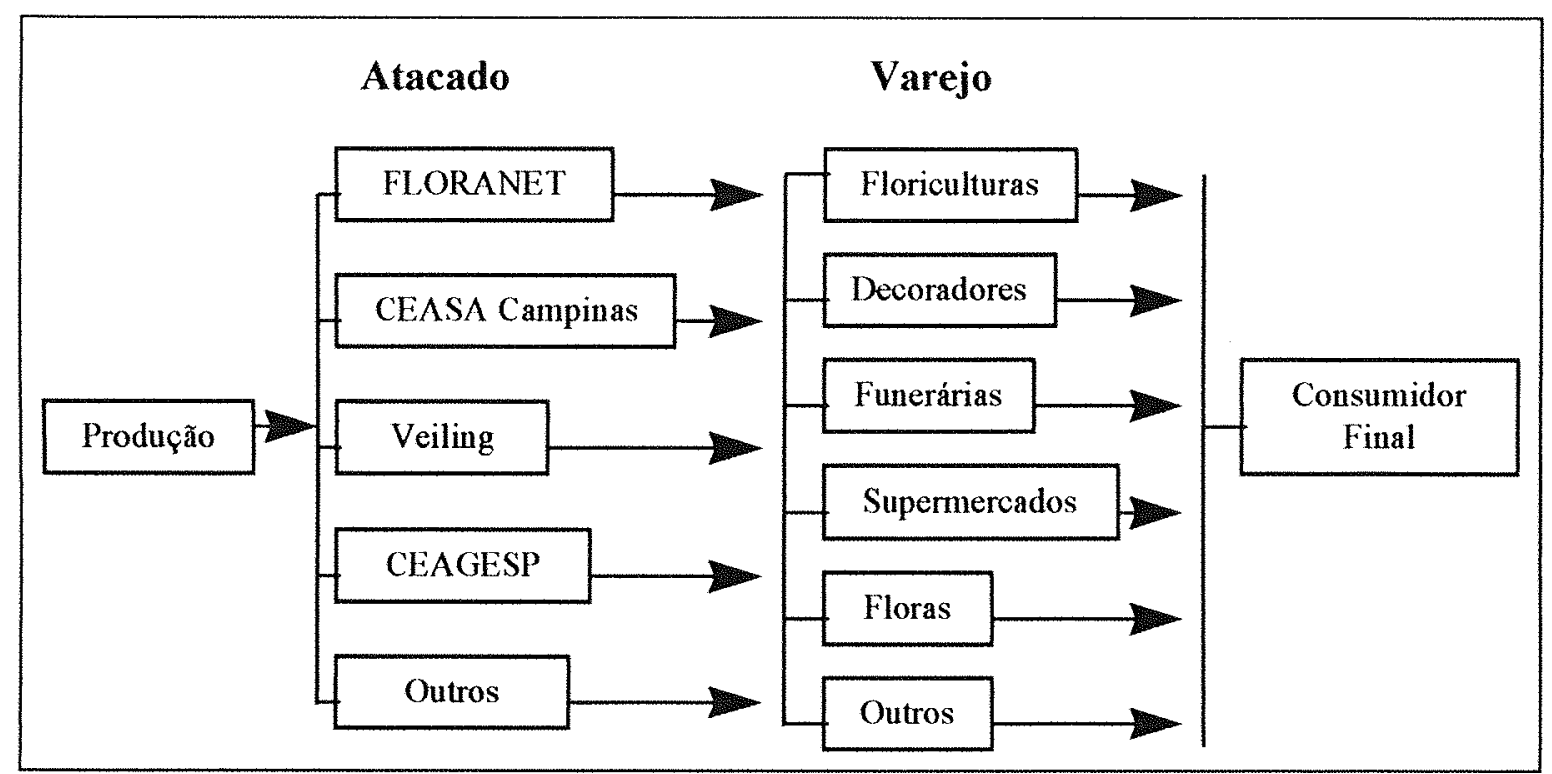

Figura 3 - Diferentes formas de distribuição varejista e atacadista de flores e plantas ornamentais.

\subsubsection{Distribuição varejista}

Em relação ao varejo, a distribuição é realizada principalmente por floriculturas e decoradores que representam cerca de 75\% do mercado (Almeida \& Aki, 1995). A Figura 4 mostra a participação dos canais de distribuição varejista de flores e plantas ornamentais sobre o total comercializado no Brasil.

Segundo estimativas de Kiyuna (1998), o mercado de flores e plantas ornamentais, um subsetor do agribusiness brasileiro, movimentou US\$700 milhões (valor no varejo) em 1995, passando para um valor estimado em US\$1,3 bilhão em 1998. Esta cifra é próxima ao valor que Aki (1998) projetou para o mercado brasileiro de flores e plantas ornamentais: movimento de aproximadamente de $\mathrm{R} \$ 1,2$ bilhões no ano de 1998 (equivalente a US\$ 1,2 bilhão convertido ao dólar médio do ano). 


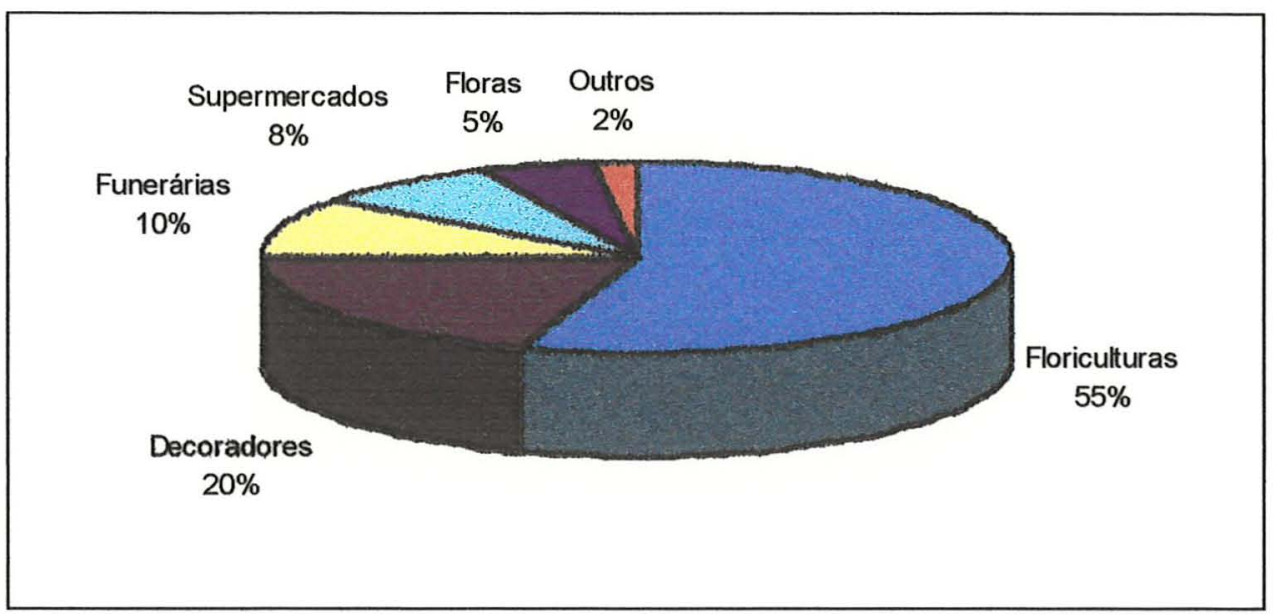

Figura 4 - Participação dos canais de distribuição varejista de flores e plantas ornamentais sobre o total comercializado no Brasil.

Fonte: Almeida \& Aki (1995)

Serão mostradas informações sobre a divisão do mercado por faturamento em produtos de 1995 até 1998 . A Tabela 2 mostra o faturamento calculado pelos preços no varejo.

O crescimento anual do mercado em termos de faturamento nominal foi de 7,58\% de 1995/1996; 11,78\% de 1996/1997 e de 1997/1998 houve um declínio de 0,73\%. De 1995 a 1998 esse crescimento foi de 19,38\%.

A floricultura paulista ocupa cerca de $60 \%$ do mercado nacional, movimentando valores em torno de US\$ 800 milhões no varejo. A Figura 5 mostra a participação (em porcentagem) do Estado de São Paulo em termos de faturamento no varejo no mercado nacional de flores e plantas ornamentais (Kiyuna, 1998).

Nas regiões do Centro Oeste, Norte, Nordeste, interior dos estados do Sul e Sudeste (exceto interior de São Paulo), denominada por Aki (1988) de região primária, o varejo oferece poucas variedades de produtos e geralmente com baixa qualidade. 
Tabela 2. Divisão do mercado por faturamento em produtos no Brasil, 1995-1998.

\begin{tabular}{|c|c|c|c|c|c|c|c|c|}
\hline Produto & $\begin{array}{c}1995 \\
(\mathrm{R} \$ \mathrm{mil})\end{array}$ & $\%$ & $\begin{array}{c}1996 \\
\text { (R\$ mil) }\end{array}$ & $\%$ & $\begin{array}{c}1997 \\
\text { (R\$ mil) }\end{array}$ & $\%$ & $\begin{array}{c}1998 \\
\text { (R\$ mil) }\end{array}$ & $\%$ \\
\hline Rosas (Dz) & 207.691 & 20,7 & 214.774 & 19,9 & 222.333 & 18,5 & 221.946 & 18,6 \\
\hline Crisântemo (Mç) & 166.907 & 16,7 & 165.885 & 15,4 & 182.289 & 15,1 & 180.495 & 15,1 \\
\hline Gérbera (Dz) & 13.415 & 1,3 & 12.792 & 1,2 & 13.128 & 1,1 & 13.141 & 1,1 \\
\hline Lirio (Mç) & 12.446 & 1,2 & 9.624 & 0,9 & 10.855 & 0,9 & 12.216 & 1,0 \\
\hline Cravo (Mç) & 24.484 & 2,4 & 27.692 & 2,6 & 28.923 & 2,4 & 29.211 & 2,4 \\
\hline Mix Flores (Mç) & 9.373 & 0,9 & 6.848 & 0,6 & 8.280 & 0,7 & 7.917 & 0,7 \\
\hline Gypsofila(Mç) & 16.665 & 1,7 & 16.458 & 1,5 & 14.958 & 1,2 & 14.763 & 1,2 \\
\hline Gladíolo(Dz) & 17.026 & 1,7 & 14.281 & 1,3 & 14.141 & 1,2 & 13.754 & 1,2 \\
\hline Outras Flores (Mç) & 38.630 & 3,9 & 86.203 & 8,0 & 106.915 & 8,9 & 110.000 & 9,2 \\
\hline Violeta (Pt11) & 56.884 & 5,7 & 54.763 & 5,1 & 50.207 & 4,2 & 46.549 & 3,9 \\
\hline Kalanchoe (Pt11) & 12.713 & 1,3 & 15.806 & 1,5 & 16.414 & 1,4 & 15.776 & 1,3 \\
\hline Crisântemo (Vb) & 44.488 & 4,4 & 40.444 & 3,8 & 46.039 & 3,8 & 44.538 & 3,7 \\
\hline Crisântemo (Pt13) & 20.626 & 2,1 & 20.330 & 1,9 & 21.584 & 1,8 & 26.133 & 2,2 \\
\hline Begônia (Pt11) & 4.669 & 0,5 & 10.294 & 1,0 & 11.582 & 1,0 & 12.494 & 1,0 \\
\hline Azaléias (Pt13) & 15.626 & 1,6 & 14.667 & 1,4 & 15.281 & 1,3 & 14.986 & 1,3 \\
\hline Outros Vasos & 75.762 & 7,6 & 89.047 & 8,3 & 134.679 & 11,2 & 137.000 & 11,5 \\
\hline Gibóia & 18.000 & 1,8 & 14.845 & 1,4 & 16.464 & 1,4 & 14.515 & 1,2 \\
\hline Outras Plantas & 102.000 & 10,2 & 112.309 & 10,4 & 129.600 & 10,8 & 120.000 & 10,0 \\
\hline Jardinagem & 127.008 & 12,7 & 133.512 & 12,4 & 146.064 & 12,1 & 147.967 & 12,4 \\
\hline Folhagens & 16.593 & 1,7 & 16.384 & 1,5 & 14.135 & 1,2 & 11.632 & 1,0 \\
\hline Total & 1.001 .006 & 100 & 1.076 .958 & 100 & 1.203.871 & 100 & 1.195 .033 & 100 \\
\hline
\end{tabular}

Dz: dúzia Mç: maço Pt11: pote $11 \mathrm{Vb}$ : vaso de barro Pt13: pote 13

Fonte: Aki (1998)

\section{Outros Estados do Brasil $40 \%$}

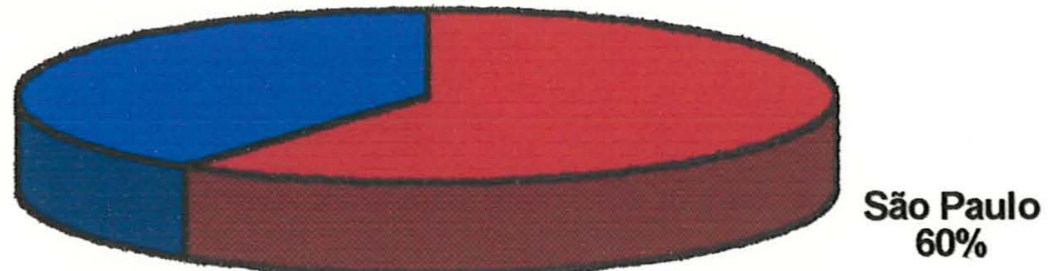

Figura 5 - Participação do Estado de São Paulo no mercado nacional de flores e plantas ornamentais.

Fonte: Kiyuna (1998) 
Nas capitais de todos os estados do país (exceto São Paulo, Rio de Janeiro, Belo Horizonte e Porto Alegre) e interior de São Paulo (região secundária), o mix de produto oferecido é mais extenso, havendo especialização por produto. A padronização já é mais forte. Verifica-se a exportação de produtos para outros estados (sobretudo de plantas tropicais, folhagens e plantas de paisagismo).

O varejo se encontra extremamente segmentado, com ênfase para o paisagismo, funerárias, supermercados e diversas categorias de floriculturas. A venda por telefone já representa 30 a $40 \%$ do total da venda e o serviço de entregas é indispensável. Como a oferta de produtos é farta, começam os problemas de vendas diretas entre fornecedor e consumidor final. Geralmente o comércio no interior é mais resistente a novos produtos que as lojas das capitais (exceção feita ao Rio de Janeiro, onde até mesmo na capital existem obstáculos para a introdução de novidades).

Nas regiões da grande São Paulo, Campinas, Porto Alegre, Belo Horizonte, Rio de Janeiro e Brasília (região madura), as flores e plantas são encontradas em supermercados, quiosques, lojas de conveniência, postos de gasolina, etc. As antigas floras se transformaram gradualmente em garden centers, que são lojas varejistas que oferecem pequena quantidade de flores de corte, flores em vaso, plantas verdes, plantas para jardim e material para jardinagem. Também oferecem alguns serviços, como cursos, pequenos arranjos, projetos de paisagismo e materiais informativos e didáticos.

A Tabela 3 mostra uma comparação em termos de volume nas regiões citadas.

As transações que ocorrem entre o setor varejista e o consumidor final são diferentes para cada tipo de varejista. Como exemplo, podemos citar floriculturas, decoradoras e supermercados que desejam atender as exigências de seus clientes. Para isso diferenciam seus produtos para cada segmento de consumidor. Nesse caso não se pode generalizar como uma transação do tipo "spot" e impessoal.

Muitas redes de supermercados estão investindo na comercialização de flores, buscando novas alternativas de apresentação ao consumidor. Para obter sucesso com a comercialização de flores, três fatores são fundamentais: qualidade, variedade e o mix adaptado ao perfil do consumidor. Essas três características combinadas vão garantir a 
aceitação do produto (Martinelli, 1998).

Entretanto existem pontos varejistas que desvalorizam o produto, como alguns supermercados e floriculturas que trabalham com a pior qualidade de flores e plantas ornamentais existentes no mercado. Estes não investem na manutenção da qualidade do produto, desconhecem técnicas de manipulação e conservação, além da falta de profissionalismo, relacionada ao atendimento, técnica de venda e informação.

Tabela 3. Tabela comparativa em termos de volume nas regiões.

\begin{tabular}{|c|c|c|c|c|}
\hline & $\begin{array}{c}\text { Região } \\
\text { Primária }{ }^{1}\end{array}$ & $\begin{array}{c}\text { Região } \\
\text { Secundária }^{2}\end{array}$ & $\begin{array}{c}\text { Região } \\
\text { Madura }^{3}\end{array}$ & Brasil \\
\hline População (hab) & 122 milhões & 15 milhões & 23 milhões & 160 milhões \\
\hline $\begin{array}{l}\text { Consumo per capita } \\
\text { anual }\end{array}$ & $\mathrm{R} \$ 2$ a 3,00 & $\mathrm{R} \$ 10$ a 15,00 & $R \$ 20$ a 30,00 & $\mathrm{R} \$ 7,50$ \\
\hline $\begin{array}{l}\text { Número de pontos de } \\
\text { venda }{ }^{4}\end{array}$ & 10.000 & 2.500 & 5.000 & 17.500 \\
\hline $\begin{array}{l}\text { Número de habitantes } \\
\text { por ponto de venda }\end{array}$ & $12 \mathrm{mil}$ & $6 \mathrm{mil}$ & $4,6 \mathrm{mil}$ & $9,1 \mathrm{mil}$ \\
\hline
\end{tabular}

Fonte: Aki (1998)

${ }^{1}$ Centro Oeste, Norte, Nordeste, interior dos estados do Sul e Sudeste (exceto interior de São Paulo).

${ }^{2}$ Capitais de todos os estados do pais (exceto São Paulo, Rio de Janeiro, Belo Horizonte e Porto Alegre) e interior de São Paulo.

${ }^{3}$ Regiões da grande São Paulo, Campinas, Porto Alegre, Belo Horizonte, Rio de Janeiro e Brasilia.

${ }^{4}$ Inclui profissionais autônomos como paisagistas e decoradores.

\subsubsection{Distribuição atacadista}

A distribuição atacadista de flores e plantas ornamentais no Brasil é realizada através de centros atacadistas públicos e privados e vendidas diretamente pelos produtores ou grupo de produtores. Esses distribuem os produtos para os atacadistas, 
supermercados, floriculturas, funerárias, feiras livres e até mesmo para o consumidor final.

No presente trabalho, a caracterização dos sistemas de distribuição, é feita para o Estado de São Paulo, que é o maior produtor do país. A distribuição nesse estado é realizada principalmente por quatro categorias distintas de sistemas de distribuição atacadista: 1) público tradicional (SPT1), representado pelo mercado de flores da Companhia de Entrepostos e Armazéns Gerais de São Paulo (CEAGESP); 2) público tradicional com um mercado permanente de flores e plantas ornamentais (SPT2), representado pelo Mercado Permanente de Flores e Plantas Ornamentais da Central de Abastecimento S/A de Campinas (CEASA); 3) cooperativo (SC), representado pelo Veiling Holambra, que vem a ser o leilão de flores e plantas ornamentais realizado diariamente nas dependências da Cooperativa Agropecuária Holambra e 4) privado (SPR), representada pela empresa FLORANET.

A Figura 6 mostra a participação dos quatro sistemas de distribuição atacadista do Estado de São Paulo, analisados neste trabalho sobre o faturamento total acumulado de janeiro a outubro de 1999.

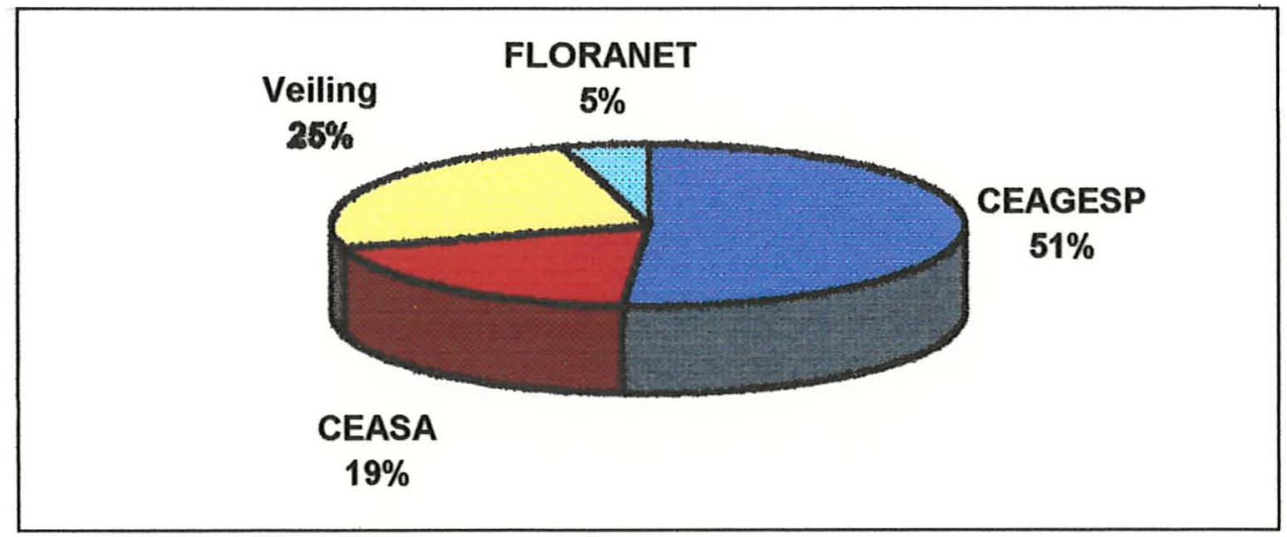

Figura 6 - Participação de quatro sistemas de distribuição atacadista do Estado de São Paulo sobre o faturamento total acumulado de janeiro a outubro de 1999.

Fonte: Dados da pesquisa 
A seguir serão caracterizadas as quatro categorias de sistemas de distribuição atacadista estudados nesse trabalho.

2.3.2.2.1 Sistema de distribuição atacadista público tradicional (SPT1)

O sistema de distribuição atacadista público tradicional (SPT1) é representado nesse trabalho pela CEAGESP, que surgiu em 1969, da fusão entre a Central Estadual de Abastecimento S.A (CEASA) e da Companhia de Entrepostos e Armazéns Gerais de São Paulo (CEAGESP).

A CEAGESP é membro das câmaras setoriais de frutas, hortaliças, cebola e alho, batata e flores e plantas ornamentais. Por determinação dessas câmaras o órgão responde pela operacionalização das propostas do Programa Paulista, cujo trabalho foi iniciado em setembro de 1977 com uma pequena equipe técnica enriquecida por estudantes de agronomia em estágio obrigatório ou residência agronômica (Gutierrez, 1999).

Atualmente a distribuição de flores e plantas ornamentais na CEAGESP ocorre na Praça da Batata, Cebola e Flores (PBCF) e no pavilhão do Mercado Livre do Produtor (MLP), na capital paulista. O funcionamento operacional desta distribuição acontece terças e sextas feiras no MLP e segundas e quintas-feiras na PBCF.

Segundo pesquisa desenvolvida por Vieira \& Albertini $^{2}$, no pavilhão do MLP existem 1.101 permissionários ${ }^{3}$, sendo 850 produtores, 250 firmas (distribuidores) e 1 cooperativa (Holambra). Na Praça da Batata existem 240 permissionários, sendo 190 produtores e 50 firmas (distribuidores).

Entre os pontos criticos existentes no processo de comercialização de flores na CEAGESP, podem ser apontados a falta de fiscalização das quantidades comercializadas;

\footnotetext{
${ }^{2}$ VIEIRA, D. P., ALBERTINI, M. A. (CEAGESP. Companhia de Entrepostos e Armazéns Gerais de São Paulo, São Paulo). Comunicação Pessoal, 1999.

${ }^{3}$ Utiliza-se a terminologia de permissionário para aquele indivíduo (empresa ou pessoa fisica) que possui box no recinto de venda, paga o condomínio e, portanto, tem permissão de comercializar os produtos dentro da estrutura (Claro, 1998).
} 
falta de padrões de classificação; falta de segurança; falta de orientação nos comunicados à imprensa, convidando os consumidores a comprarem diretamente no local, transformando-o em um varejão de flores e o longo periodo de comercialização, que se prolonga por mais de doze horas (Arruda et al., 1996).

Ademais, interesses corporativistas e uma complexa malha de relacionamentos informais criam um ambiente de ineficiência e de encarecimento do produto, que pode resultar em prejuízo ao consumidor final.

De acordo com Vieira \& Albertini ${ }^{4}$, existem diferentes tipos de compradores na CEAGESP. A Tabela 4 a seguir, lista as atividades dos compradores no pavilhão do mercado livre do produtor e na Praça da Batata, segundo levantamento feito junto aos compradores no periodo de agosto a setembro de 1998.

Tabela 4. Atividades dos compradores no pavilhão do MLP e Praça da Batata.

\begin{tabular}{lcc}
\hline Atividade & MLP $^{1}$ & Batata $^{1}$ \\
\hline Comércio $^{2}$ & 38,82 & 50,63 \\
Consumidor & 34,21 & 1,25 \\
Paisagismo & 21,05 & 14,38 \\
Distribuidor & 3,29 & 31,88 \\
Funerárias/Igrejas & 1,32 & 0,63 \\
Órgãos Públicos & 1,32 & 1,25 \\
\hline
\end{tabular}

Fonte: Vieira \& Albertini (1999)

${ }^{1}$ Porcentagem do total de compradores entrevistados.

${ }^{2}$ Mercados, floriculturas, feiras, sacolões e bancas.

\footnotetext{
${ }^{4}$ VIEIRA, D. P., ALBERTINI, M. A. (CEAGESP. Companhia de Entrepostos e Armazéns Gerais de São Paulo, São Paulo). Comunicação Pessoal, 1999.
} 
2.3.2.2.2 Sistema de distribuição atacadista público tradicional com um mercado permanente de flores e plantas ornamentais (SPT2)

O Sistema de distribuição atacadista público tradicional com um mercado permanente de flores e plantas ornamentais (SPT2), é representado nesse trabalho pela CEASA Campinas.

A cidade de Campinas possui uma localização geográfica privilegiada, próxima às principais regiões produtoras e às vias de acesso que passam pela cidade (Anhanguera, Bandeirantes e D. Pedro).

O mercado surgiu como alternativa à comercialização corrente na CEAGESP e cresce a cada mês. De acordo com Stenico ${ }^{5}$, esse mercado permanente conta atualmente com 504 boxes: 384 boxes de $24 \mathrm{~m}^{2}$ cada um e mais 120 boxes em processo de licitação. O total de área coberta desse mercado é $30.000 \mathrm{~m}^{2}$ (até final de 1999 essa área era de $18.872 \mathrm{~m}^{2}$ ). Atualmente possui 302 permissionários, dos quais 238 são produtores (sendo 76 de flores de corte, 88 de flores de vaso e 74 de plantas ornamentais), 20 atacadistas e 44 vendem acessórios para o setor.

A ampliação do Mercado de Flores é um estudo antigo e representa a vontade do permissionário, que viu a importância de ampliar o mix de produtos e completar alguns setores para, sem concorrer com os atuais permissionários, atrair novos clientes para o mercado. As obras de melhoria e ampliação do mercado, com exceção dos estacionamentos - feitos com recursos próprios - vêm sendo realizadas em parceria com os permissionários, que, acreditando nos beneficios de tais empreendimentos, têm investido no entreposto campineiro (Lima, 1999).

O Mercado de Flores de Campinas é um exemplo claro de como o setor público pode atuar de modo estimulante, exercendo o papel de articulador entre os diversos agentes da cadeia produtiva. Nesse caso, a CEASA congregou os produtores, sobretudo da região próxima ao entreposto, ávidos por novos espaços de comercialização,

\footnotetext{
${ }^{5}$ STENICO, A. R. P. (CEASA Campinas. Divisão de Orientação Técnica - Departamento de Flores). Comunicação Pessoal, 2000.
} 
auxiliando da mesma forma na atração dos compradores do futuro mercado. Organizou a construção e bancada pelos próprios interessados.

A carência de indicadores não permite medir, na sua íntegra, os impactos sociais, econômicos e comerciais do mercado de flores. Pode-se avaliar sua importância e seus desdobramentos, pelo fato de que só em Campinas o número de floriculturas passou de cerca de 70 para mais de 200 .

Os produtos comercializados no Mercado de Flores alcançam grandes distâncias, uma vez que todas as semanas ali comparecem compradores provenientes de Porto Alegre, Belo Horizonte, Brasilia e Recife.

Segundo pesquisa desenvolvida pelo IBRAFLOR (1999), a área cultivada e a procedência dos produtores associados ao CEASA Campinas estão apresentadas na Tabela 5.

Tabela 5. Área cultivada e procedência dos produtores associados ao CEASA Campinas.

\begin{tabular}{lcc}
\hline Produtores & Área cultivada (ha) & Procedência \\
\hline Flores de corte & 331 & $70 \%$ de Atibaia - SP \\
Flores de vaso & 152 & $60 \%$ de Atibaia -SP \\
Plantas ornamentais & 1.311 & $61 \%$ de Itapetininga - SP \\
\hline \hline Total & 1.794 &
\end{tabular}

Fonte: IBRAFLOR (1999)

A CEASA Campinas conta atualmente com 3.721 clientes. A Tabela 6 mostra a procedência desses clientes. 
Tabela 6. Procedência dos clientes da CEASA Campinas.

\begin{tabular}{lc}
\hline Clientes/ Procedência & Quantidade \\
\hline Região Sudeste & 3.574 \\
Região Sul & 83 \\
Região Centro-Oeste & 59 \\
Região Nordeste & 4 \\
Outros & 1 \\
\hline \hline Total & 3.721 \\
\hline
\end{tabular}

Fonte: IBRAFLOR (1999)

2.3.2.2.3 Sistema de distribuição atacadista cooperativo (SC)

O Sistema de distribuição atacadista cooperativo (SC) é representado nesse trabalho pelo Veiling Holambra. Segundo Rooyen \& Optiz (1997), é um sistema que administra a estrutura de vendas de flores através de um leilão eletrônico diário de preços decrescentes ( $70 \%$ das vendas) e intermediação de contratos negociados em balcão ( $30 \%$ das vendas).

O processo de leilão baseia-se em um "pregão" diário. Os produtores são associados à Cooperativa Agrícola Holambra e entregam sua produção exclusivamente para oferta no Veiling (Aki, 1992). Já a intermediação é uma prestação de serviços para realizar contratos de compra e venda de produtos entre produtores e compradores para entregas programadas. Neste caso de transação, não é necessário que o produto passe pelo Veiling. Na grande maioria, os contratos de intermediação são anuais e estabelecem preços e quantidades fixas (Claro, 1998). O principal comprador da intermediação é o atacadista que atende principalmente cash and carrys, gardens centers e supermercados (Arruda et al., 1996)._.

O leilão é a peça chave do sistema, pois estimula a competição entre compradores para a aquisição dos produtos, o que dá muita transparência a esse mercado. A 
inexistência deste sistema levaria os produtores de flores a uma posição de negociação muito desfavorável, em função da perecibilidade do produto (Rooyen \& Optiz, 1997).

De acordo com Arruda et al. (1996), o sistema tem como principais características ser um mercado transparente e confiável; concentrar diariamente a oferta e a procura, através de lotes, permitindo a melhor formação de preço para cada produto no momento da comercialização; desenvolver uma padronização nos produtos que permite uma diferenciação de mercado; agilizar a comercialização a fim de minimizar o espaço de tempo entre a colheita e o produto nas mãos do consumidor final e ser um dos pontos referenciais de mercado, fornecendo informações claras e objetivas que permitem a formação de um preço justo.

O sistema de leilões com preços decrescentes foi implantado pela primeira vez na Holanda, em 1887. O sistema diferia do leilão tradicional, uma vez que os lances de compra não eram dados pelos compradores no sentido crescente de preços, mas sim, identificados em um grande painel que iniciava com um preço elevado e ia caindo até que o primeiro comprador manifestava o seu interesse pelo produto (Zylbersztajn, 1992).

O Veiling Holambra foi implementado em 1989 e situa-se nas proximidades de uma grande concentração de produtores de flores e plantas ornamentais, dentro do município de Holambra, a cerca de $30 \mathrm{Km}$ da cidade de Campinas - SP.

No prédio principal do Veiling existem áreas para armazenamento das flores e plantas destinadas à comercialização, as quais são usualmente trazidas do produtor através de transportadoras, no dia anterior ao da venda e áreas para colocação dos lotes já comprados, que aguardam o acondicionamento nas dezenas de caminhões utilizados pelos distribuidores que estão posicionados ao longo do perímetro do galpão produto (Rooyen \& Optiz, 1997).

As flores e plantas já são trazidas ao Veiling em lotes homogêneos, classificadas pelo produtor e acondicionadas em carrinhos com prateleiras. A classificação dada pelo produtor é conferida no galpão pela administração do Veiling. Nos critérios de classificação utilizados são considerados aspectos associados a fitossanidade, danos mecânicos, asseio do produto e embalagem, ponto de colheita, etc. 
A área utilizada para o leilão é de um auditório fechado com capacidade para cerca de 250 compradores. Nesse recinto encontra-se o "relógio" eletrônico que apresenta diversas informações para os compradores e que possibilita o leilão de preços decrescentes. Entre o auditório e o relógio passam os carrinhos contendo os lotes a serem leiloados. Na frente de cada assento do auditório há uma mesa que contém um teclado e um display eletrônico que permitem que o comprador controle e monitore a aquisição dos lotes no leilão.

O leilão pode negociar mais de 3700 lotes por dia, se inicia às 7 da manhã $\mathrm{e}$ dura aproximadamente de 2 a 4 horas. A negociação do lote é muito rápida. O lote entra no recinto e suas informações são apresentadas em placares eletrônicos. O relógio começa a apresentar preços mais elevados que o suposto preço de negociação e gradualmente vai reduzindo o preço até que algum comprador "pare" o relógio, utilizando-se de um botão situado na sua mesa de controle. Esse preço marcado pelo relógio, ao ser parado, é o preço que o comprador pagará pelo lote. Imediatamente um novo lote é leiloado e o processo se repete.

O sistema Veiling apresenta o controle eletrônico do crédito dado aos compradores. Cada comprador tem um limite de crédito que impede que este faça compras acima desse teto, o que minimiza riscos (Rooyen \& Optiz, 1997). Segundo dados da IBRAFLOR (1999), o índice de inadimplência nos últimos anos foi de $0,6 \%$. De acordo com Rooyen \& Optiz (1997), outro aspecto relevante que visa o controle da oferta é o sistema de preços mínimos para a aquisição. Nesse sistema, introduzido na Holanda em 1948, sempre que no leilão o preço de um lote cai abaixo de um limite preestabelecido, chamado preço mínimo, esse lote é retirado da negociação e destruído publicamente. Em média esse mecanismo destrói entre 1 a 5\% das flores leiloadas.

Segundo Arruda et al. (1996), esse preço mínimo tem sido formado pelo custo de colheita, embalagem, transporte para o Veiling e pela taxa do Veiling. Se esse for muito baixo, permitirá a especulação do produtor.

Os atacadistas e floristas, cadastrados como clientes do Veiling, podem ser agrupados em cinco grupos: 
a) atacadistas de linhas: fazem rotas, ponto a ponto, por todo o país (inclusive atendendo o próprio CEAGESP e a CEASA Campinas);

b) despachantes: compram por encomenda das floriculturas e fretam o transporte até o destinatário;

c) comissionários: compram para a floricultura que retira o produto no próprio Veiling. O comissionário é um comprador de flores e plantas que, diante de uma comissão, compra no relógio para terceiros. Essa pessoa pode ser especializada em determinado produto. Funciona como um corretor na bolsa de valores. No setor comercial do Veiling, estão à disposição as diversas informações sobre os comissionários cadastrados;

d) Cash and Carry: são grandes supermercados de flores, dois deles com sede dentro do terreno do Veiling e que mantêm estoques para venda a outros atacadistas, floristas e consumidores;

e) floriculturas: compram para sua própria necessidade.

Atualmente o Veiling Holambra possui 162 produtores associados e 295 compradores. A área plantada pelos produtores associados é de 663 ha, sendo 274 ha em estufas. São comercializadas 215 espécies de flores e plantas, com aproximadamente 2068 variedades (IBRAFLOR, 1999).

Os dez produtos mais vendidos no Veiling Holambra entre 1992 a 1999 estão mostrados na Tabela 7. 
Tabela 7. Os 10 produtos mais vendidos no Veiling Holambra (em milhares de unidades).

\begin{tabular}{lcccccccc}
\hline Produto & 1992 & 1993 & 1994 & 1995 & 1996 & 1997 & 1998 & 1999 \\
\hline Violetas (vasos) & 9.185 & 14.111 & 15.302 & 17.381 & 19.123 & 20.582 & 15.266 & 14.288 \\
Rosas (dúzias) & 5.453 & 6.501 & 7.571 & 9.054 & 10.040 & 12.200 & 11.831 & 7.976 \\
Kalanchoes (vasos) & 1.887 & 2.257 & 3.205 & 3.590 & 4.245 & 6.145 & 6.853 & 8.292 \\
Crisântemo (maços) & 1.202 & 1.517 & 1.920 & 2.091 & 2.277 & 1.646 & 1.416 & 1.602 \\
Azaléias (vasos) & 854 & 1.199 & 1.250 & 1.351 & 1.611 & 1.276 & 1.017 & 831 \\
Crisântemo (vasos) & 391 & 444 & 791 & 1.148 & 1.382 & 1.862 & 1.818 & 1.860 \\
Gladiolos(dúzias) & 1.301 & 1.152 & 905 & 748 & 695 & 513 & 495 & 540 \\
Cravos (dúzias) & 190 & 83 & 193 & 372 & 387 & 459 & 435 & 264 \\
Gérbera (dúzias) & 262 & 307 & 302 & 259 & 260 & 324 & 234 & 374 \\
Gypsofila (maços) & 489 & 372 & 319 & 212 & 174 & 155 & 60 & 107 \\
\hline
\end{tabular}

Fonte: Elaborado pelo autor a partir de Optiz ${ }^{6}$

2.3.2.2.4 Sistema de distribuição atacadista privado (SPR)

O Sistema de distribuição atacadista privado (SPR) é representado nesse trabalho pela FLORANET.

A familia Reijers atua na área de produção de flores desde 1972, iniciando seu trabalho sob uma mesma marca a partir de 1994, com o estabelecimento do Grupo Reijers (atual FLORANET). A empresa, com sede no Município de Holambra-SP, por motivos de desacordo com as políticas da Cooperativa Holambra, decidiu pelo desligamento, necessitando criar seu próprio sistema de distribuição. O novo sistema foi inaugurado em outubro de 1998 e está dividido em 3 empresas diferentes: uma responsável pela área comercial, uma segunda pela área administrativa e uma terceira responsável pela distribuição (operadora logística).

\footnotetext{
${ }^{6}$ OPTIZ, R. (Veiling Holambra- Unidade de Flores e Plantas Ornamentais). Comunicação Pessoal, 2000.
} 
A FLORANET possui uma pequena sede, com uma câmara fria com $430 \mathrm{~m}^{2} \mathrm{e}$ plataforma de embarque/desembarque. A área total construída da empresa é de $1400 \mathrm{~m}^{2}$. Conta atualmente com um cadastro de 8 produtores e 120 clientes associados. O produtor cadastrado não precisa entregar 100\% de sua produção para a empresa. Os principais produtos comercializados são rosas, cravos, alstroemérias, boca de leão, violetas, gérberas e azaléias.

O funcionamento do sistema de distribuição ocorre da seguinte forma: as unidades de produção passam sua disponibilidade de produto, alimentando um banco de dados para a área comercial. Clientes fazem seus pedidos na maioria das vezes via telefone ou fax. Alguns fazem o pedido diretamente no escritório de vendas. Os pedidos são enviados às respectivas unidades de produção, que recebem o pedido por cliente, identificando-os através de etiquetas com código de barras. São enviadas para a central logística, de cada produtor diretamente para o cliente, apenas os produtos já vendidos, podendo já serem retirados pelos clientes. $\mathrm{O}$ transporte é responsabilidade do produtor. Os pedidos devem ser feitos com um dia de antecedência.

Os critérios de classificação são discutidos com os produtores e são estabelecidos padrões. A padronização e controle de qualidade são realizados na produção. O produto possui a característica de maior durabilidade, já que o tempo entre a colheita e a distribuição é curto. Além disso, a empresa investe na marca FLORANET, colocando sua logomarca nas embalagens de comercialização e em algumas propagandas em revistas especializadas.

Desde final de 1999, a FLORANET tem trabalhado com um sistema eletrônico de comercialização. O objetivo é viabilizar a comercialização eletrônica virtual de flores e plantas através da internet, organizando os fluxos de informações e produtos, a fim de aproximar e dar mais agilidade nas operações comerciais entre as diversas regiões produtoras e centro de consumo através dos atacadistas/distribuidores. Os fornecedores são os produtores, associações de produtores, cooperativas e mercados regionais. Os clientes são atacadistas, cash and carry e garden centers (Bongers et al., 1999). 
Na Tabela 8 estão resumidas algumas informações sobre a localização, ano de inauguração, número de produtores e consumidores, faturamento acumulado de janeiro a outubro de 1999 e área total utilizada para a comercialização das quatro categorias de sistemas de distribuição atacadista. 


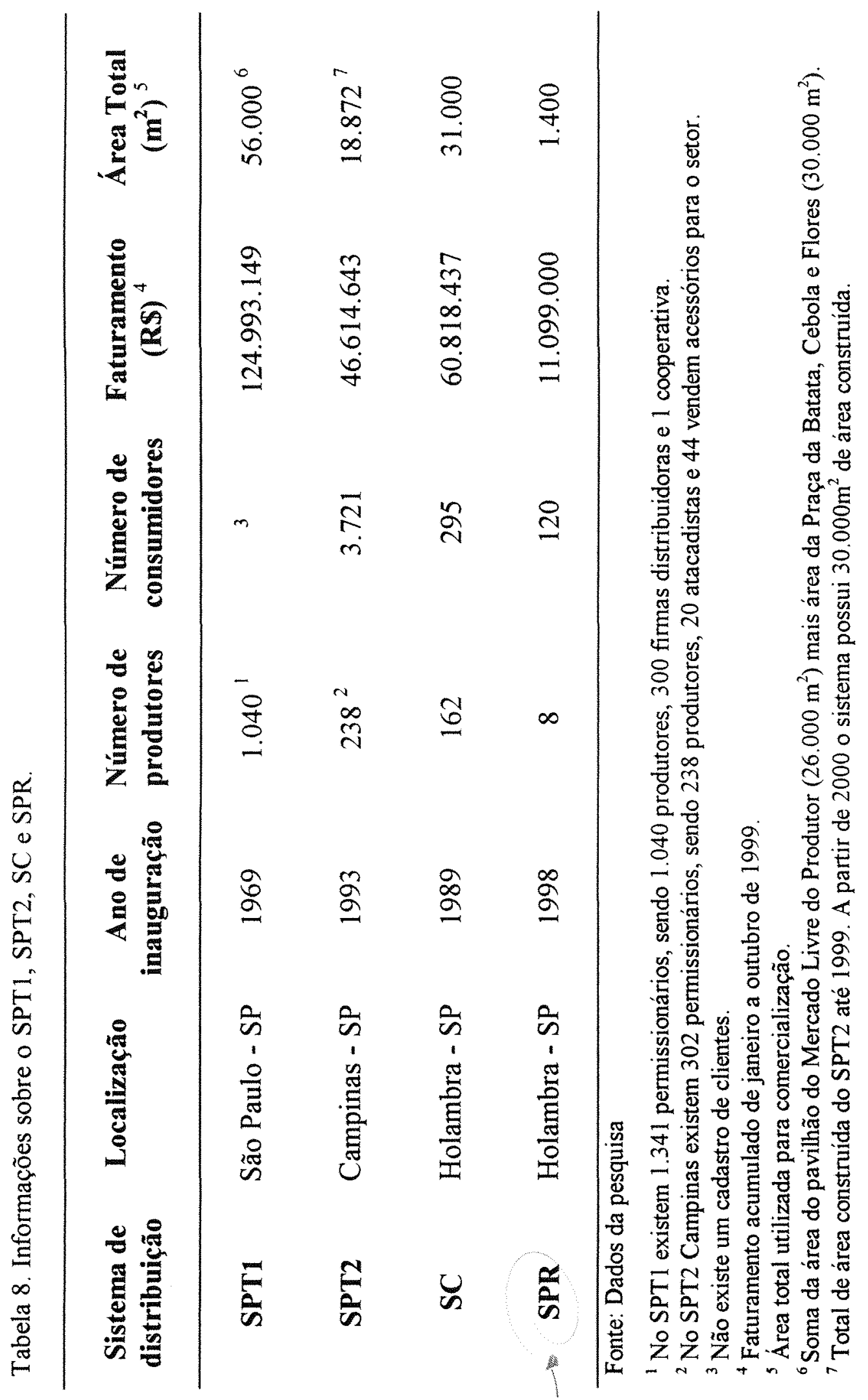




\subsubsection{A produção de flores e plantas ornamentais}

No Brasil, existem cerca de 3.600 produtores de flores e plantas ornamentais trabalhando em 4.500 ha. A atividade é caracterizada pela presença de pequenos e médios produtores, além de um pequeno número de grandes empresas (Veiling-Holambra, 1997). De acordo com Rooyen \& Optiz (1997), no campo emprega-se de 1 a 3 pessoas por hectare, nos viveiros 3 a 5 pessoas e em estufas de 4 a 10 pessoas.

No setor produtivo da floricultura se destacam o elevado emprego de mão-deobra e investimento de capital por área, o rápido ciclo de produção (de 4 a 6 meses), a pequena área utilizada (5 a 20 hectare) e o alto valor agregado (Almeida \& Aki, 1995).

De modo geral, pequenos e médios produtores dedicam-se exclusivamente à floricultura, sendo que $100 \%$ da receita auferida são geradas pela atividade. Os produtores moram na propriedade, pequenos sítios sempre próximos à cidade e contam com alguns empregados residentes.

Grande parte destes produtores é filiada a alguma associação ou cooperativa. Em São Paulo existem 8 associações regionais de produtores e duas cooperativas, Holambra e Holambra II.

Estima-se que o valor total do segmento de produção de flores no Estado de São Paulo, em 1998, foi de US\$ 240 milhões (Kiyuna, 1998).

De acordo com Arruda et al. (1996), a floricultura no Estado de São Paulo manteve-se por muitas décadas pouco desenvolvida e tecnificada, caracterizando-se como uma atividade conduzida de forma amadorística. A situação foi sendo gradativamente alterada com o crescimento e especialização da produção e atualmente está consolidada como uma atividade de importância sócio-econômica no estado.

A estrutura de produção de flores no Estado de São Paulo pode ser vislumbrada através dos dados oriundos do Levantamento Censitário de Unidades de Produção Agropecuária do Estado de São Paulo (LUPA) 1995/96. O Censo acusou a existência de 
1.214 Unidades de Produção Agropecuária (UPAs) cultivando flores em 1995 (Kiyuna, 1998). Na Tabela 9 são mostradas as regiões de maior concentração de UPAs.

Tabela 9. Regiões de maior concentração de UPAs - 1995 .

\begin{tabular}{lc}
\hline Regiões produtoras & Número de UPAs \\
\hline Mogi das Cruzes & 259 \\
Bragança Paulista & 238 \\
Mogi Mirim & 156 \\
São Paulo & 130 \\
Sorocaba & 107 \\
\hline
\end{tabular}

Fonte: Kiyuna (1998)

Considerando o conceito de área homogênea (AH) utilizado no LUPA, como "um conjunto de talhões com as mesmas características produtivas (os talhões podem não ser contíguos, mas devem estar dentro do mesmo imóvel rural)", o Estado de São Paulo apresentava, ao todo, 1.839 áreas homogêneas cultivadas com flores (Kiyuna, 1998). Na Tabela 10 são apresentadas as categorias de flores com maior número de áreas homogêneas.

Tabela 10. Categorias de flores com maior número de áreas homogêneas (AHs) - 1995.

\begin{tabular}{lc}
\hline Flores & Número de AHs \\
\hline rosa & 385 \\
crisântemo & 237 \\
branquinha (gypsofila) & 89 \\
violeta africana & 70 \\
\hline
\end{tabular}

Fonte: Kiyuna (1998) 
Segundo Kampf (1997), a mão-de-obra predominante no Estado de São Paulo é contratada, $86 \%$ como mensalistas e $4 \%$ como diaristas eventuais. A reduzida parcela de mão-de-obra familiar $(10 \%)$ atesta o forte caráter empresarial da floricultura paulista.

2.3.3.1 Exportação e importação de flores e plantas ornamentais no Brasil

É importante ressaltar a pequena parcela de flores e plantas ornamentais produzidas no Brasil que são exportadas, assim como as importadas. Historicamente, o balanço das importações e exportações brasileiras de plantas vivas e produtos de floricultura foi superavitário. No período 1992-98, o pico da exportação brasileira nessa categoria ocorreu em 1995, com valor de US\$ 13,9 milhões, enquanto a importação representou US\$ 5,3 milhões. Considerando o periodo de janeiro/1992 a junho/1998, a relação entre os valores de importação e exportação foi 31\%. Esta relação, que em 1992 foi de 6\%, evoluiu rapidamente para 56\%,54\% e 63\% em 1996, 1997 e 1998 (até junho), respectivamente, mostrando a participação crescente da importação no balanço comercial (Tabela 11) (Kiyuna, 1998).

Entre os entraves à exportação, existem problemas tributários, a falta de padronização dos produtos e problemas de ordem fitossanitária.

O país vem importando flores e plantas ornamentais principalmente da Bolívia, Colômbia, Chile e Equador, além de alguns países Europeus. 
Tabela 11. Importações e exportações brasileiras de plantas vivas e produtos de floricultura, 1992-98.

\begin{tabular}{lccc}
\hline Periodo & $\begin{array}{c}\text { Importação } \\
\text { US\$ FOB }\end{array}$ & $\begin{array}{c}\text { Exportação } \\
\text { US\$ FOB }\end{array}$ & $\begin{array}{c}\text { Imp./Exp. } \\
\%\end{array}$ \\
\hline 1992 & 658.744 & 11.706 .193 & 6 \\
1993 & 978.502 & 13.221 .437 & 7 \\
1994 & 1.781 .228 & 12.634 .964 & 14 \\
1995 & 5.311 .569 & 13.903 .748 & 38 \\
1996 & 6.638 .525 & 11.855 .354 & 56 \\
1997 & 5.944 .382 & 11.004 .990 & 54 \\
$1998^{1}$ & 3.666 .372 & 5.825 .960 & 63 \\
\hline \hline Total & 24.979 .322 & 80.152 .646 & 31 \\
\hline
\end{tabular}

Fonte: Kiyuna (1998)

'valor acumulado de janeiro a junho.

A análise dos valores do comércio exterior brasileiro de flores frescas para buquês e de flores secas, em 1996 e em 1997, indica que as flores frescas representam 40 a 50\% da importação total de plantas vivas e produtos de floricultura, atingindo, em 1996 e 1997, US\$ 2,6 milhões e US\$ 3,1 milhões, respectivamente. Por outro lado, as exportações brasileiras de flores frescas, no mesmo periodo, foram de US\$ 420 mil e US\$ 262 mil, indicando grande desequilibrio no balanço comercial das flores frescas. Ressalta-se, entretanto, o valor de exportações de flores secas no mesmo período de US\$ 1 milhão por ano (Tabela 12). 
Tabela 12. Valor da importação e exportação de flores no Brasil, por categoria, 1996-97 (em US\$ FOB).

\begin{tabular}{lcccc}
\hline & \multicolumn{2}{c}{ Valor de importação } & \multicolumn{2}{c}{ Valor de exportação } \\
Ano & Flores frescas $^{1}$ & Flores secas $^{2}$ & Flores frescas & Flores secas \\
\hline 1996 & 2.461 .220 & 425.659 & 420.416 & 1.157 .418 \\
1997 & 3.116 .150 & 94.417 & 262.162 & 1.026 .722 \\
\hline \hline Total & 5.577 .370 & 520.076 & 682.578 & 2.184 .140 \\
\hline
\end{tabular}

Fonte: Kiyuna (1998)

' Flores e seus botões, frescos, cortados para buquês.

${ }^{2}$ Flores e seus botões, secos, etc. cortados.

\subsubsection{Os insumos para produção de flores e plantas ornamentais}

Este segmento é constituído por empresas de mudas e sementes, de fertilizantes e defensivos, de máquinas e implementos e equipamentos para plasticultura e embalagens.

O comércio de mudas e sementes no Brasil começou a desenvolver-se como uma forma de especialização dentro do setor produtivo, como nos países mais desenvolvidos, onde existe um elevado nível de especialização das atividades.

Salvo o caso da produção de algumas mudas, como as de crisântemo, que já é bastante estruturada no país, o comércio de mudas é baseado na importação de países como EUA, Holanda, Japão, Dinamarca e Israel, destacando-se as mudas de rosas, orquídeas, cravos e gypsofila. Entre as sementes, tem-se as de lisianthus, limonium e statice.

Atualmente, existem produtores que já estão trabalhando com avançados processos de biotecnologia (cultura de tecidos), que investem pesadamente em verdadeiros laboratórios de produção de mudas, com orientação tecnológica adequada. 
Tanto na produção de mudas originadas por sementes como na produção de mudas geradas de forma vegetativa, existe uma tendência de aumento no número de empresas especializadas na produção e comercialização de mudas já aclimatadas, através de parcerias com empresas internacionais, as quais recebem royalties por seu material genético melhorado.

As transações entre empresas que fornecem mudas e sementes importadas e os produtores rurais, ocorrem via mercado, já que existem diversos fornecedores e as transações ocorrem com freqüência. Geralmente existem agentes especializados (empresas) que são responsáveis por intermediar as vendas. Já as transações entre empresas de produção de mudas, como é o caso de empresas que produzem mudas de crisântemo, dá-se por contratos de longo prazo, que envolvem serviços pós-venda.

No setor de fertilizantes, existem algumas empresas multinacionais que atuam no ramo de fertilizantes e formulações para aplicação na forma líquida, através de técnicas como a de fertirrigação. Os fertilizantes, pela particularidade das culturas, são geralmente aplicados sob a forma líquida, pelo sistema de irrigação através do gotejamento, microaspersão ou pela pulverização.

Em relação aos defensivos, há um número bastante restrito de produtos registrados para flores junto ao Ministério da Agricultura. A morosidade para registrar novos produtos advém do período experimental para o teste e liberação. Apesar da existência de produtos mais eficientes, em geral já usados no primeiro mundo, e muitos deles menos tóxicos que os disponiveis no mercado nacional, estes não podem ser utilizados pela falta de registro.

Quanto ao uso de plástico na floricultura, os primeiros experimentos datam da década de 40, tendo sido, rapidamente difundido nos EUA e Europa. Atualmente, o Japão é o maior consumidor, respondendo por $45 \%$ da demanda mundial.

No Brasil, seu uso começou na década de 70 , porém, somente com a utilização do polietileno de baixa densidade é que houve um crescimento rápido, sob diversos usos: filmes, lonas, túneis e estufas. 
Em relação às embalagens, o material varia de acordo com a espécie e padrão, além do seu nicho de mercado, podendo ser de papel tipo manilha, celofane, plástico microperfurado, caixas de papelão, etc.

Além de melhorar a apresentação do produto, a embalagem tem como função: acondicionar o produto de forma adequada; informar o consumidor como manusear e cuidar do produto; levar a marca do produtor até o consumidor e através do uso de códigos de barra, melhorar o controle da distribuição e comercialização, principalmente no caso dos supermercados.

As transações existentes entre os produtores rurais e as empresas de fertilizantes, defensivos, equipamentos para plasticultura e embalagens dão-se via mercado, já que existem diversos fornecedores e as transações ocorrem com freqüência. Como citado por Neves (1995), a indústria de fertilizantes, assim como as de defensivos, não são integradas até a distribuição, e os contratos se fazem com agentes, que realizam o contato final com os consumidores.

O setor de máquinas e equipamentos para flores e plantas ornamentais é deficiente no Brasil, tanto em termos de disponibilidade no mercado como em tecnologia. Assim sendo, vários equipamentos específicos são importados por não existir similar no mercado nacional.

Como máquinas, compreende-se a utilização de micro tratores e de potência média, dependendo do sistema de produção e da extensão da área cultivada. Como equipamentos, compreendem-se os sistemas de irrigação, pulverização, nebulização, controladores de temperatura, umidade, luminosidade, aparelhos de monitoramento das condições ambientais, além de implementos de uso acoplando ao trator, como arados rotativos.

As transações entre o setor de máquinas e equipamentos com os produtores rurais ocorrem através de negociações que envolvem contratos de venda, já que os produtores possuem direitos de manutenção e reposição. A compra de máquinas e equipamentos é realizada em lojas especializadas e a garantia do produto é de responsabilidade da indústria fornecedora. 


\section{REFERENCIAL TEÓRICO}

\subsection{Abordagens sobre eficiência}

Os estudos econômicos relativos à eficiência utilizam modelos tradicionais de Microeconomia, como a função de produção. Esta identifica a forma de solucionar os problemas técnicos da produção, por meio da apresentação das combinações de fatores que podem ser utilizados para o desenvolvimento do processo produtivo. Pode-se conceituá-la como sendo a relação que mostra qual a quantidade obtida do produto, a partir da quantidade utilizada dos fatores de produção (Carvalho, 1998).

A análise microeconômica parte do princípio que a função de produção assim definida admite sempre que o empresário esteja utilizando a maneira mais eficiente de combinar os fatores e, consequentemente, irá obter a maior quantidade produzida do produto. Todavia, a fim de que o empresário possa realizar este tipo de ação da maneira mais eficiente possivel, recomenda-se que seja utilizado determinado processo de produção.

Assim, é interessante conceituar processo de produção, como sendo a técnica por meio da qual um ou mais produtos serão obtidos a partir da utilização de determinadas quantidades de fatores de produção. Se esse processo de produção for simples, obter-se-á, a partir da combinação dos fatores, um único produto; quando, a partir da combinação dos fatores, for possível produzir mais de um produto, ter-se-á um processo de produção múltiplo, ou uma produção múltipla. 
Percebe-se, pelos conceitos apresentados, que a função de produção indica o máximo de produto que se pode obter com as quantidades dos fatores, uma vez escolhido o processo de produção mais conveniente. A diferença entre os dois conceitos é extremamente sutil. O processo de produção, na realidade, indica quanto de cada fator se faz necessário para obter certa quantidade de produto. Por seu turno, a função de produção indica o máximo de produto que se obtém a partir de uma dada quantidade de fatores, mediante a adequada escolha do processo de produção. Em outras palavras, podem existir diversas formas de combinar os fatores para se obter certa quantidade de produto. Cada uma dessas formas caracteriza um processo de produção. Por conseguinte, quando se fala em função de produção no sentido genérico, admite-se implicitamente que o processo ou a forma escolhida de combinar os fatores é a mais eficiente, pois as demais formas ou processos menos eficientes já foram desprezados.

Considerando a hipótese simplificada da firma produzir apenas dois produtos, a teoria econômica, para procurar explicar as alternativas de escolha que a firma tem, se vale de uma ferramenta gráfica de grande auxilio para a compreensão do problema, a comumente denominada Curva de Possibilidade de Produção. A economia está produzindo com eficiência, quando para produzir mais de um determinado bem, precisa produzir menos de outro determinado bem, mantendo-se sobre sua curva de possibilidade de produção (Carvalho, 1998).

A curva de possibilidade de produção é traçada supondo-se que (1) a economia tem uma quantidade fixa de recursos (incluindo mão-de-obra, materiais e capital) e (2) a economia está usando seus recursos de forma eficiente (Wessels, 1998). A Figura 7 mostra diferentes combinações de bens de consumo (como alimentos e cremes dentais) e bens de investimento (como fábricas e máquinas). No ponto $\mathrm{A}$, a economia não está usando seus recursos com eficiência, pois poderia ter mais de ambos os bens. A economia só vai estar usando seus recursos com eficiência quando estiver num ponto sobre sua curva de possibilidade de produção (como por exemplo o ponto B). 


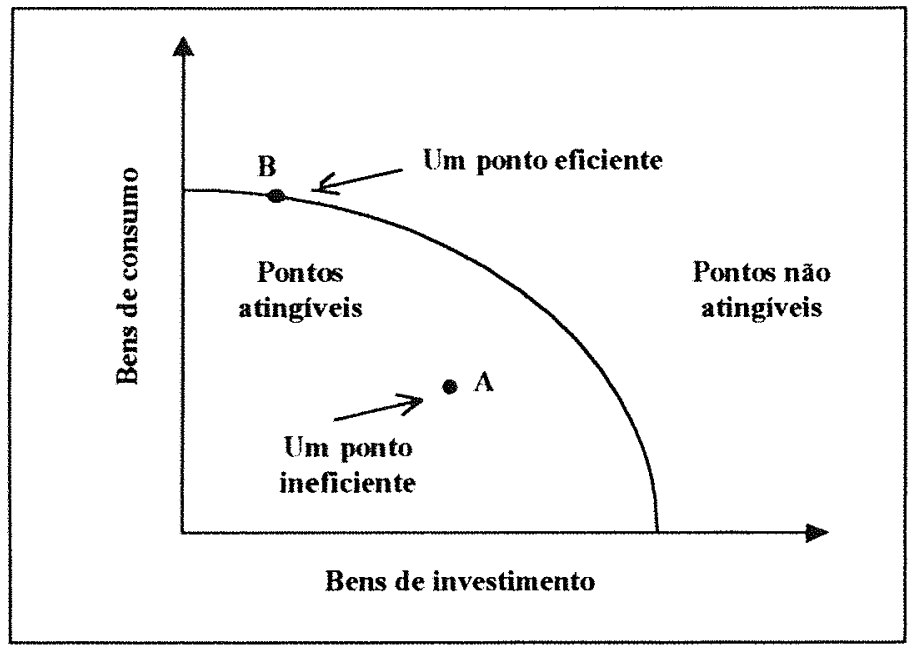

Figura 7 - Curva de possibilidade de produção.

Fonte: Wessels (1998)

Trabalhos recentes vêm cada vez mais fazendo uso das chamadas "funções de produção de fronteira" para analisar a eficiência produtiva. Está última abordagem trabalha com uma estimativa da função de produção correspondente à "melhor prática produtiva", permitindo a comparação da posição relativa das unidades analisadas em termos dos respectivos "desvios" em relação ao melhor padrão produtivo (Saheli \& Macedo, 1998).

A eficiência produtiva tem dois componentes. O puramente técnico (físico) e o alocativo (preço). O primeiro refere-se à habilidade de evitar perdas produzindo tanto produto quanto os insumos utilizados permitem ou utilizando o mínimo de insumo possivel no processo de produção. Nesse caso, a análise da eficiência técnica pode ter orientação no sentido de aumentar o produto ou poupar insumos. $O$ segundo componente refere-se à habilidade de combinar insumos e produtos em proporções ótimas, dados os seus preços (Lovell, citado por Tupy \& Yamaguchi, 1998)

Portanto, de acordo com Lau \& Yotopoulos (1971), uma firma é considerada tecnicamente mais eficiente que outra, quando dadas as mesmas quantidades de insumos quantificáveis, esta firma conseguir uma produção maior continuamente (supondo que a 
tecnologia seja a mesma para as firmas). Uma firma é considerada alocativamente eficiente quando recebe de cada fator de produção exatamente aquilo que paga para utilizar o mesmo.

Uma firma além de ser eficiente na utilização dos insumos (eficiência técnica e alocativa) deverá, também, ser eficiente no produto (eficiência de escala). Uma firma eficiente no produto opera onde existem retornos constantes de escala, ou seja, onde uma mudança no produto resulta em mudança proporcional nos custos. Por outro lado, produzir mais de um produto pode resultar em vantagens adicionais, por exemplo, redução de custos. Se o custo de produzir conjuntamente for menor do que o custo resultante do processo de produção individual, diz-se que a economia de escopo está presente. Conclui-se, portanto, que uma firma poderá ser considerada eficiente no produto, na utilização de insumos ou em ambos. A eficiência no produto poderá ser analisada a partir dos conceitos de eficiência de escala (um único produto) e escopo (mais de um produto) e a eficiência na utilização dos insumos a partir da análise da eficiência técnica e alocativa (Evanoff \& Israilevich, citados por Tupy \& Yamaguchi, 1998).

Uma função de produção de fronteira é uma extensão do conceito de função de produção, que mostra o máximo de produto que é possivel se obter com um dado nível de insumos. Desta forma, a sua estimação implica a imposição da restrição segundo a qual nenhuma unidade produtiva é capaz de exceder este máximo a um dado nível de desenvolvimento tecnológico. Não se considera que todas as unidades estejam utilizando a melhor prática produtiva, pelo contrário, podem existir restrições peculiares a um número delas que as impeçam de utilizar a técnica mais moderna (ausência de mão-deobra especializada; utilização de estoque de capital obsoleto, etc.) conduzindo-as, desta forma, a um nível de produção inferior ao da fronteira (Saheli \& Macedo, 1998).

A noção de eficiência econômica é analisada pela Microeconomia comparandose as diferentes estruturas de mercado. No regime de concorrência perfeita, deriva-se a eficiência econômica quando o mercado estiver em equilibrio de longo prazo (o preço do produto será igual ao custo total mínimo) (Spínola \& Troster, 1998). 
Desde que o fluxo de entrada e saida do setor seja livre, a sua produção será ampliada à medida que existirem oportunidades de investimentos lucrativos, de maneira que, a longo prazo, o preço diminuirá e a disponibilidade de produto será maior.

De acordo com Spínola \& Troster (1998), se um setor que opera em regime de concorrência perfeita for monopolizado, irá ocorrer a elevação do preço e a redução da produção. Devido à possibilidade de existência de lucro monopolista a longo prazo, em razão das barreiras à entrada de novas firmas no setor, o preço do produto pode ser superior ao seu custo total médio minimo.

A eficiência econômica sob monopólio não é máxima, porque o monopolista não utiliza necessariamente uma planta de produção ótima ou não produz a quantidade ótima, dada a escala de planta existente.

Isso nos leva ao conceito de eficiência de Pareto. Uma alocação de recursos é no sentido de Pareto, quando não é possível melhorar a situação de um setor sem piorar a situação de outro. O monopólio não é eficiente no sentido de Pareto, pois é possível baixar os preços, sem haver impacto em outros setores (o que já não pode ocorrer em concorrência perfeita)

Evidentemente, em muitos mercados existem ineficiências. Muitas dessas causadas por restrições tecnológicas, embora outras sejam causadas por restrições regulatórias. A falta de informação e as barreiras à entrada são responsáveis por ineficiências que oneram toda a sociedade, em beneficio de poucos.

Outro ponto importante é que o mercado por si só não garante a eficiência. Por um lado, o governo é fundamental para que o mercado exista, pois o mercado existe porque existe propriedade, e a propriedade é tal porque assim é definida e defendida pelo governo.

Por outro, existe uma série de bens para os quais mercado não assegura uma alocação eficiente. Uns exemplos são os bens públicos - defesa nacional, etc. - que fazem com que a quantidade a ser produzida e os recursos a serem alocados sejam decididos de forma mais eficiente num processo político. 
Marques \& Aguiar (1993) citam como um dos indicadores de eficiência na alocação de recursos a noção de "lucros normais", que deveriam prevalecer igualmente para toda a economia na ausência de barreiras à livre movimentação de recursos. Em uma economia perfeitamente livre, baixo retorno num setor indica má alocação e recursos devem ser transferidos. Por outro lado, altos retornos em outros setores indicam que há espaço para outras empresas elevarem a produção e pode-se mesmo dizer que ganhos persistentemente altos em alguns setores indicam restrição monopolistica à produção.

Por uma série de razões, restrições à livre competição resultam então em não cumprimento de vários requisitos que são esperados da sociedade. Isto é, não há máxima utilização dos recursos disponíveis, e o pouco que é utilizado o é de forma ineficiente, e o resultado é que não há produto para todos.

No entanto, os modelos tradicionais de Microeconomia são descritos de maneira diferente do mundo real. Concorrência perfeita, informação disponível sem custos e capacidade ilimitada dos agentes para solucionar problemas são elementos fundamentais aos modelos microeconômicos (Azevedo, 1998).

Esse afastamento da realidade não é necessariamente um problema para a análise microeconômica, uma vez que seu objetivo não é representar o mundo real, mas apresentar um arcabouço para interpretá-lo melhor. Contudo, a análise microeconômica encontra limites e não oferece interpretações adequadas para situações observadas na prática. Isso é particularmente verdadeiro no estudo de mercados que operam em concorrência imperfeita. Nesse caso, não é razoável supor que as empresas são tomadoras de preço. Ao contrário, empresas de grande porte têm políticas de determinação de seu preço, cujo objetivo é a ampliação da capacidade da empresa de fixar seu preço acima dos custos de produção.

Para lidar com problemas dessa espécie, recorre-se à literatura de Organização Industrial, que surgiu como reação à incapacidade da Microeconomia tradicional em dar respostas adequadas a problemas reais das empresas e dos mercados.

Costuma-se reportar a origem da Organização Industrial à década de 30. Coase, citado por Azevedo (1998), foi um dos autores que contribuiu em apresentar uma visão 
mais aprofundada da firma. Sua preocupação era entender o escopo, abrangência e os limites de uma empresa. Uma empresa não é caracterizada somente por transformar insumos e produtos. Existem diversos modos de se organizar a produção e esses modos são relevantes para a eficiência do sistema econômico.

Reunir as principais contribuições da Organização Industrial em um único corpo não é tarefa fácil. De acordo com Azevedo (1998), o autor que se dedicou a esta tarefa foi Scherer $^{7}$, não apresentando propriamente uma teoria, mas uma compilação das principais contribuições, sintetizadas no paradigma de Estrutura-Conduta-Desempenho.

O paradigma de Estrutura-Conduta-Desempenho tem como principal preocupação a avaliação do desempenho de um determinado mercado frente ao desempenho esperado em uma situação ideal de concorrência perfeita. Em outras palavras, procura-se avaliar em que medida as imperfeições do mecanismo de mercado limitam a capacidade deste em atender as aspirações e demandas da sociedade por bens e serviços. O conforto se dá, portanto, entre o desempenho econômico de uma estrutura dita "imperfeita" e o desempenho ideal competitivo. Sendo considerada uma variável dependente, assume-se que o desempenho econômico pode ser alterado mediante intervenções sobre a estrutura de mercado e a conduta das firmas, o que serviria como guia para as políticas públicas.

O grande vilão nos mercados oligopolizados é o exercício do poder de monopólio, ou seja, a capacidade de uma firma em fixar seus preços acima do custo marginal. Havendo poder de monopólio por parte de algumas firmas participantes do mercado, três tipos de ineficiência podem surgir: a) alocativa; b) produtiva; e c) dinâmica.

A ineficiência alocativa surge diretamente do exercício do poder de monopólio, ou seja, do fato de o preço ser superior ao custo marginal. Isso faz com que o consumo seja inferior àquele que seria socialmente desejado, de tal modo que se abre espaço para

\footnotetext{
${ }^{7}$ Sua primeira tentativa de síntese data de 1970 , sendo a última em co-autoria, Scherer \& Ross (1990).
} 
uma intervenção do Estado no sentido de promover a concorrência e corrigir essa distorção. Mais importante ainda é a ineficiência produtiva, que se refere à perda de motivação por parte da firma que desfruta de lucros elevados, refletindo-se em um pequeno esforço gerencial e produtivo. Sobre isso, Jonh Hicks, citado por Azevedo (1998), afirmou que "o pior custo dos monopólios é a preguiça dos gerentes". A concorrência inibe diretamente esse tipo de ineficiência ao pressionar a empresa a lutar pela sua sobrevivência. Uma ação do governo no sentido de promover a concorrência pode, portanto, ser benéfica também nesse caso. Finalmente, a ausência de concorrência pode implicar ineficiência dinâmica, uma vez que as empresas vêem-se menos estimuladas a promover investimentos em capacitação tecnológica. A concorrência é o grande motor da busca de novos produtos, mercados e processos produtivos. Sem concorrência, o estímulo à atividade inovativa vê-se diminuido.

O paradigma de Estrutura-Conduta-Desempenho é um dos principais instrumentos de análise das políticas de defesa da concorrência. Uma vez identificados quais elementos da estrutura de mercado ou práticas das empresas são danosos à concorrência, o Estado pode fazer uso da legislação antitruste, a fim de atenuar as ineficiências derivadas do poder de monopólio.

O desempenho do sistema econômico é determinado pelo conjunto de estratégias que definem a conduta das firmas. Cada empresa tem a possibilidade de desenvolver estratégias com a finalidade de ganhar participação no mercado; no entanto, cada estratégia tem um impacto distinto sobre o desempenho. Por exemplo, gastos em pesquisa e desenvolvimento de novos produtos refletem-se no aumento da eficiência dinâmica, contribuindo para a melhoria da qualidade e/ou queda do preço dos produtos. Por outro lado, uma estratégia de cartelização com o objetivo de elevação dos preços tem efeito oposto. Introduz-se ineficiências alocativa e produtiva, tendo, reflexos negativos sobre o desempenho econômico.

Não obstante as empresas tenham autonomia para traçar sua conduta a partir de um leque de estratégias, esse conjunto de estratégias disponiveis é determinado pela estrutura de mercado em que a empresa se insere. Este é o ponto em que o paradigma de 
Estrutura-Conduta-Desempenho mais se aprofundou. Se houver barreiras elevadas à entrada, há espaço para o exercício do poder de monopólio, permitindo que a empresa faça uma política de elevação dos preços. Se, ao contrário, não houver barreiras à entrada e à saida, as firmas têm pouco espaço para a elevação dos preços. Assim, a estrutura de mercado condiciona a decisão estratégica (Azevedo, 1998).

A estrutura, por sua vez, é determinada pelas condições básicas de oferta e demanda, compreendendo características do produto, dos consumidores, da tecnologia, entre outras. Características da tecnologia, expressas na função de produção, definem a existência de economias de escala. Estas, por seu turno, induzem uma estrutura concentrada. Pelo lado da demanda, características do produto permitem ou não a sua diferenciação, sendo um elemento da estrutura.

Os efeitos causais secundários são freqüentemente ignorados, embora possam ser importantes no longo prazo. Por exemplo, uma política de investimento em pesquisa e desenvolvimento - um elemento da conduta - pode dotar uma empresa de acesso privilegiado a uma nova tecnologia, permitindo que ela tenha vantagem absoluta de custos - um elemento da estrutura. $\mathrm{O}$ efeito é considerado secundário porque é necessário tempo considerável de investimentos para reverter uma dada situação da estrutura de mercado.

O paradigma de Estrutura-Conduta-Desempenho foi o principal instrumento de intervenção sobre os mercados, embora várias críticas lhe tenham sido endereçadas. Duas dessas críticas se sobressaem: seu caráter estático e a ausência de uma teoria consolidada. Considera a estrutura de mercado como uma variável exógena e limitante quando a evolução tecnológica é intensa. Nestes casos, a estrutura pode mudar com rapidez, desqualificando a sua ênfase enquanto variável determinante. Finalmente, o paradigma é uma tentativa de síntese de um conjunto de teorias, muitas vezes incompativeis. Não se consegue - e não se pretende - chegar a uma teoria consolidada.

Uma abordagem alternativa, que aparece complementando alguns pontos importantes da Organização Industrial tradicional, é a Economia dos Custos de Transação, considerada um ramo da Nova Economia Institucional. 
A seguir será apresentado o referencial teórico da Nova Economia das Instituições, que dará suporte às discussões sobre aspectos abordados neste trabalho.

\section{2 $\mathrm{O}$ ambiente institucional e a economia dos custos de transação}

O conceito de agribusiness relaciona-se à soma de todas as operações desde a pesquisa até o consumidor final, no sentido macroeconômico, envolvendo todos os setores (produtor, processador, comercializador de alimentos e fibras), de todos os produtos (Davis \& Goldberg, 1957). Já o sistema agroindustrial no agribusiness é um conceito mais restrito, interessante para a análise de setores e produtos isolados, tais como sistema agroindustrial avícola, do trigo, citrícola, entre outros. É uma análise por produto, envolvendo seu fluxo desde a pesquisa até o consumidor final.

Para a competitividade ${ }^{8}$ de um setor é necessário compreender seu sistema agroindustrial, analisando as relações existentes entre os agentes que o compõem. Neste trabalho, a análise das transações entre produtores e sistemas de distribuição de flores e plantas ornamentais, serão analisadas pela ótica da Nova Economia das Instituições (NEI), utilizando a vertente da Economia dos Custos de Transação (ECT).

Segundo Zylbersztajn (1995), a evolução da vertente institucional passa a ganhar espaço dentro da teoria econômica especialmente a partir dos trabalhos de Oliver Williamson, nas décadas de 70,80 e 90, dando seqüência ao trabalho fundamental de Ronald Coase (1937).

A literatura da Nova Economia das Instituições, permite construir um quadro conceitual bastante realista para abordar a eficiência das relações contratuais entre os diferentes elos dos sistemas de agribusiness, permite analisar a coordenação competitiva do sistema como um todo vis-à-vis o comportamento de consumidores intermediários e finais, permite avançar na definição das formas de organização mais adequadas, e muitos

\footnotetext{
${ }^{8}$ Segundo Kennedy et al (1997), competitividade é definida como a habilidade de gerar lucro e manter a participação no mercado.
} 
outros pontos freqüentemente negligenciados pela economia neoclássica tradicional. Em outras palavras, a abordagem institucional pode prover a ligação natural entre a economia teórica e sua aplicação orientada para o estudo das organizações e instituições do agribusiness e suas estratégias de ação, com ênfase, por exemplo, nas questões de competitividade (Jank, 1996).

O primeiro conceito importante apresentado pela NEI refere-se ao papel desempenhado pelas instituições. De acordo com Machado Filho (1997), as instituições são os limites que as sociedades se impõem para estruturar as relações políticas, econômicas e sociais. As instituições podem ser tanto formais (constituições, leis, direitos de propriedade) como informais (crenças, tradições, códigos de condutas e costumes).

As normas e leis da sociedade determinam os direitos de propriedade que os individuos possuem, tais como o direito de vender um ativo, o direito de usar e receber renda dele, ou o direito de herdá-lo. De acordo com Alston (1998), os direitos de propriedade fazem valer-se de duas maneiras: os próprios indivíduos fazem valer seus direitos, através de sanções sociais, ou pelo poder de coerção do Estado.

Os direitos de propriedade, juntamente com as normas existentes e a tecnologia, determinam os custos de produção (os custos de produção neoclássicos, associados com os custos de combinar os insumos para obter os produtos) e os de transação, que são os custos "invisiveis" da produção, incluindo os esforços de monitorar os trabalhos, coordenar os fatos físicos da produção e monitorar o uso do capital físico e financeiro empregado no processo produtivo.

Tanto a tecnologia como os direitos de propriedade podem afetar os custos de transação de várias formas. A tecnologia, tanto na área agricola quanto industrial, geralmente reduz, por exemplo, os custos de monitoramento (por exemplo através da padronização dos processos de produção, reduzindo a variação da produtividade marginal do trabalho), ou os custos de transação da coordenação do trabalho (através do uso de informática nos diversos controles existentes na produção).

Quanto à influência das normas e dos direitos de propriedade nos custos de transação, Alston (1998) exemplifica que se numa determinada cultura as pessoas 
realmente acreditam no trabalho sério (por tradição ou por incentivos passados), então os custos de monitoramento são menores. Da mesma forma, se os direitos de propriedade numa sociedade permitem, por exemplo, que se demitam trabalhadores negligentes, os referidos custos também são menores.

North afirma ter sido Coase o primeiro cientista econômico a estabelecer as conexões entre instituições, custos de transação e teoria neoclássica. Os resultados preconizados pela teoria neoclássica só são obtidos quando não existem custos para se transacionar (Machado Filho, 1997).

O pressuposto fundamental da Economia dos Custos de Transação (ECT) é que o funcionamento dos mercados tem custos, em contrapartida à visão dada pela economia neoclássica, que ocorre em um ambiente sem custos associados ao funcionamento da economia.

$\mathrm{Na}$ Economia dos Custos de Transação é adotada uma visão contratual da firma, que conforme Williamson (1985), é vista como um "nexo de contratos" que disciplinam as transações, entendidas como as "transformações de um produto através de interfaces tecnologicamente separáveis". A unidade analítica é a transação.

Uma transação entre dois elementos de um sistema agroindustrial não se dá sem custos. Antes do inicio da transação, existem custos da procura, obtenção da informação, do conhecimento do parceiro, entre outros. São os custos de transação ex-ante (Neves, 1995).

Os custos ex-post são os custos de mensuração e monitoramento do desempenho, custos de renegociações, etc.

"Os custos de transação ex-ante e ex-post são interdependentes e são comparativos com outros contratos (mais eficientes que estes, mais ineficientes que aqueles - análise discreta comparada), e se originam, principalmente, através da imperfeição da informação e a conseqüente assimetria na repetição da informação entre os agentes (uma divergência na percepção da informação possui o mesmo efeito) e pela racionalidade limitada dos agentes. Estas características criam condições de incerteza nas transações" (Neves, 1999, p.74). 
Segundo Alston (1998), os custos de transação incluem os custos de negociar e fazer valer os contratos. Em algumas sociedades as normas informais podem ser suficientes para garantir a negociação, da mesma forma que costumes de comunidades bem estabelecidos podem reduzir o comportamento oportunista, reduzindo os custos de transação.

A ECT se baseia em dois pressupostos comportamentais básicos: racionalidade limitada e oportunismo.

A racionalidade limitada assume que os indivíduos agem racionalmente, mas de modo limitado. Esse pressuposto implica que o agente se empenhará em obter aquilo que considera melhor para si. No entanto, a obtenção de informações necessárias às decisões que levem a esse objetivo é limitada, ou seja, o recurso "racionalidade" é escasso, implicando custos à sua utilização. Devido a esses custos, os agentes limitam o uso da cognição, o que implica que suas decisões não necessariamente corresponderão àquelas que seriam obtidas empregando-se racionalidade plena (Zylbersztajn, 1995).

O oportunismo é o outro pressuposto comportamental, que resulta da ação dos indivíduos na busca do auto-interesse. Entretanto, o auto-interesse pode ser buscado de maneira não-oportunista. Oportunismo parte de um princípio de jogo não-cooperativo, no qual a informação que um agente possa ter sobre a realidade não acessivel a outro agente pode permitir que o primeiro desfrute de algum beneficio do tipo monopolístico.

Existem mecanismos para controlar adequadamente as transações. Williamson (1985) lista quatro tipos principais de estruturas de controle: controle via mercado, controle trilateral, controle bilateral e unilateral.

O controle via mercado é associado a transações não específicas ocasionais ou recorrentes. É simples e requer consultar a própria experiência para continuar o relacionamento ou mudar. $\mathrm{O}$ mercado funciona protegendo as partes do oportunismo, e o sistema de preços carrega todas as informações.

O controle trilateral é recomendado para transações ocasionais de ativos médios ou muito específicos. Nestes casos, o controle via mercado é insatisfatório. Por sua vez, montar uma estrutura de controle especifica pode não ser economicamente atraente. É 
uma forma intermediária de controle, onde terceiros dão assistência, resolvem disputas e avaliam o desempenho (ex: arquiteto monitorando a obra).

O controle bilateral é uma estrutura especializada de controle para o caso de transações recorrentes de ativos médios ou muito específicos. Como as transações são recorrentes, permite que os custos da estrutura sejam diluídos.

Por fim, o controle unilateral dá-se em atividades integradas verticalmente.

O modelo de Williamson (1996) estabelece uma comparação entre estruturas de governança distintas com fatores teóricos determinantes destas estruturas, utilizando um critério de minimização de custos de transação.

A estrutura de governança é, de acordo com Williamson (1996), o arranjo de normas, relações e procedimentos que regem uma determinada transação. Outras estruturas de governança na troca de direitos de propriedade existem, e em muitas situações simultaneamente, mesmo que possa haver um modelo superior em termos de eficiência.

A escolha entre os diversos modos de se governar uma transação, ou seja, entre as diferentes estruturas de governança, considera a decisão entre fazer (produzir o bem sob estrutura hierárquica e administração própria), comprar (usar o mercado), ou adotar formas hibridas entre estes dois extremos, predominando a forma mais eficiente, que é aquela que minimiza não somente os custos de produção, como também os custos de transação. Custos de transação elevados tornam ineficientes a utilização do mercado, privilegiando as formas hibridas ou hierárquicas; por outro lado, quanto menores os custos de transação, menos razões existem para que as relações sejam feitas em bases hierárquicas (Moraes, 1999).

As transações apresentam certas características (atributos) mensuráveis ${ }^{9}$, ou seja, apresentam dimensões relacionadas à especificidade dos ativos envolvidos, à incerteza, e à freqüência das transações, que somadas ao pressupostos comportamentais

\footnotetext{
${ }^{9}$ Ao perceber que as transações apresentam atributos mensuráveis, Williamson permite que cada transação seja dimensionada conforme o respectivo atributo, permitindo ordenar os diferentes custos de transação envolvidos em cada caso, justificando diferentes formas organizacionais emergentes em cada um.
} 
da teoria (racionalidade limitada e comportamento oportunista), definem as estruturas organizacionais mais eficientes (governança via mercado, via formas hibridas ou via forma hierárquica).

A especificidade dos ativos refere-se ao grau no qual o ativo pode ser reempregado em usos alternativos e por usuários alternativos sem sacrificio de seu valor, ou seja, é o quanto aquele investimento é específico para a transação e quão custosa é a sua realocação. Ativos específicos são reempregados com perda de valor.

Williamson (1996) identifica seis tipos de especificidade de ativos: 1) locacional (referente à localização relativa de firmas responsáveis por etapas sucessivas da mesma cadeia produtiva, favorável à economia de despesas com armazenagem e transporte); 2) temporal (investimento realizado para garantia de ganho no tempo em que se processa a transação, que são importantes no caso de produtos perecíveis); 3) humana (referente à experiência profissional adquirida); 4) fisica (características fisicas inerentes ao produto transacionado cujo uso é específico); 5) dedicadas (investimento do tipo sunk costs, que são ativos irrecuperáveis) e 6) marca (capital que se materializa no nome de um produto ou empresa).

À medida que a especificidade aumenta, aumentam também as implicações decorrentes de comportamento oportunistas dos agentes, pois surgem quase-renda associadas. De acordo com Azevedo (1996), quase-renda é definida como a diferença entre o retorno de um ativo empregado em uma transação específica e seu retorno em um emprego alternativo.

A Figura 8 mostra a relação entre os custos das diferentes estruturas de governança e o nível de especificidade dos ativos $(k)$. As curvas $m(k), x(k)$ e $h(k)$ representam respectivamente as estruturas de governança via mercado, híbridas e hierárquica. À medida que $\mathrm{k}$ aumenta, as relações de menores custos passam da forma mercado (até o ponto A) para híbridas (intervalo A-B) e hierárquica (após o ponto B). 


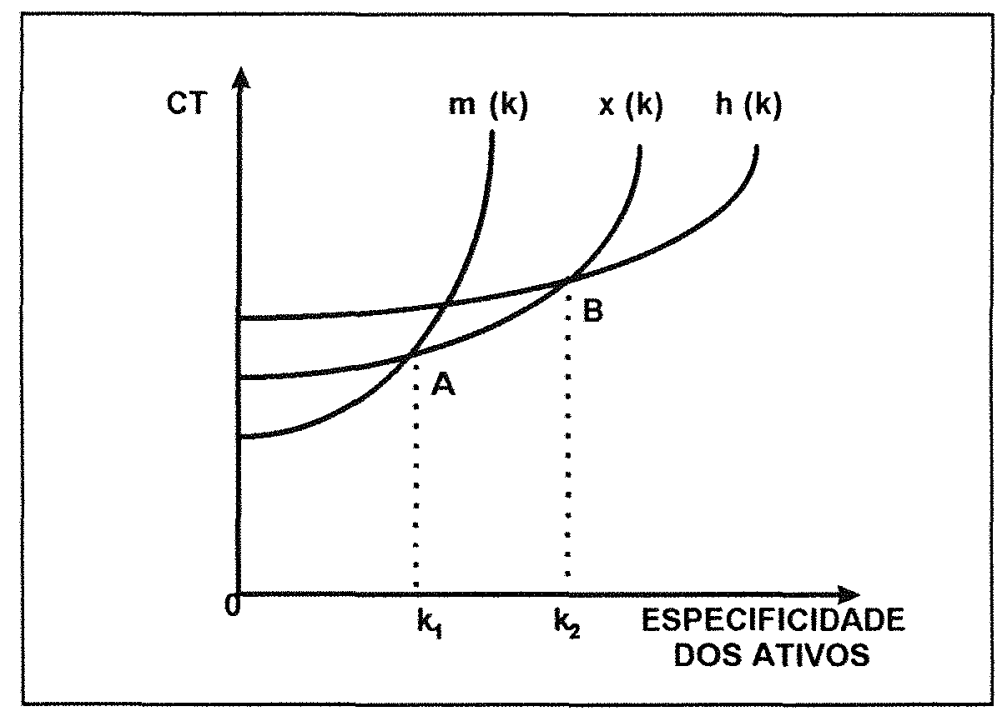

Figura 8 - Relação entre alternativas de governança.

sendo:

$\mathrm{m}(\mathrm{k})=$ governança via mercado

$\mathrm{x}(\mathrm{k})=$ governança via contratual ou hibrida

$h(k)=$ governança hierárquica

$\mathrm{CT}=$ custo de transação

A freqüência com que as transações ocorrem tem relação direta com escala de produção, viabilizando investimentos em ativos específicos e reduzindo a incerteza acerca do comportamento dos atores (Mezzomo, 1997). A repetição das transações permite que as partes se conheçam, reduzindo incertezas; que se construa uma reputação em torno de uma marca, aumentando a especificidade de ativos; e se crie, em alguns casos, um compromisso confiável entre as partes para promover a continuidade da relação contratual (Azevedo, 1996).

Em termos de freqüência as transações são classificadas em recorrentes, ocasionais ou únicas. Quanto maior a freqüência das transações, maiores as vantagens de se manter estruturas especializadas com menores custos fixos médio (Mezzomo, 1997).

Porém, de acordo com Rindfleisch \& Heide, citados por Neves (1999), "até 1997 os pesquisadores em ECT ainda não estavam tendo sucesso em confirmar as 
hipóteses sobre freqüência, e diversos estudos falharam em encontrar associações entre freqüência e governança hierárquica (integração vertical)" (p.78).

Com relação à incerteza, esta traz problemas devido aos distúrbios inesperados das transações e às dimensões necessárias para as estruturas de monitoramento e controle. Se grandes, acabam sendo onerosas. O alto grau de incerteza traz alto custo de transação. Há basicamente dois tipos de incerteza: a de contingência (estado da natureza) e a de comportamento estratégico (comportamento dos rivais). Ou seja, as transações com maior incerteza demandam estruturas de controle mais complexas, com custo muito elevado, interferindo na forma como as transações ocorrerão (Neves, 1995).

\subsubsection{Aplicações da ECT na análise de sistemas agroindustriais}

Serão citados alguns trabalhos empíricos que aplicaram os conceitos da ECT na análise de sistemas agroindustriais. $\mathrm{Na}$ apresentação de alguns trabalhos quantitativos, serão descritas as variáveis relevantes em cada um dos casos para a escolha entre os diversos modos de se governar uma transação, considerando a decisão entre fazer, comprar ou adotar formas híbridas entre esses dois extremos. Não se pretende percorrer todos os trabalhos produzidos com aplicações da ECT, mas apenas apresentar algumas contribuições nessa área.

Ribeiro, B. (1998) analisou empiricamente os elementos que influenciaram o processo de escolha dos distintos arranjos institucionais existentes no transporte de madeira entre florestas e fábricas de celulose no Brasil. Mais especificamente, o trabalho descreveu a transação de contratação dos serviços de transporte principal - transporte de madeira entre as áreas reflorestadas e as fábricas de celulose e buscou justificativas que explicassem tanto a diversidade do tamanho das transportadoras contratadas, como a existência de integração vertical parcial da frota. Para atender os objetivos do trabalho foi realizado coleta de dados junto às principais empresas da indústria nacional de celulose. 
Partiu-se do pressuposto de que as variáveis utilizadas pela ECT podem explicar tanto a diversidade do tamanho das transportadoras contratadas, como a existência de integração vertical parcial da frota. Esperava-se que niveis relativamente maiores de especificidade e incerteza estariam associados a maiores proporções de integração vertical parcial. Nessa análise foi utilizado o Teste Exato de Fisher para verificar se as magnitudes das especificidades calculadas estavam ou não correlacionadas com a opção pela integração parcial ou pela tercerização total.

Os resultados dos testes estatísticos não corroboraram o pressuposto, pois não foi possivel verificar correlação entre as variáveis proxy escolhidas para medir as dimensões da transação e escolha por integrar-se verticalmente ou contratar serviços de terceiros. Dentre as variáveis medidas, apenas aquela associada ao número médio de caminhões contratados por transportadora mostrou alta correlação com a opção por integração vertical total ou parcial, concluindo que as companhias de celulose, cujos serviços de transporte apresentam integração vertical parcial, contratam pequenas empresas de transporte ou mesmo caminhoneiros autônomos, enquanto aquelas companhias que optaram pela terceirização total dos serviços de transporte contratam transportadoras de maior porte.

Em relação ao tamanho das transportadoras contratadas, esperava-se que baixos niveis de incerteza e especificidades estariam relacionados à contratação de pequenas transportadoras ou caminhoneiros autônomos. Buscou-se nas variáveis proxy que medem as dimensões da transação, explicações para o tamanho das empresas contratadas.

Os resultados obtidos foram compativeis com o pressuposto de que altos níveis de especificidade estariam associados à contratação de grandes transportadoras, assim como a contratação de pequenas transportadoras está associada a baixos níveis de especificidades.

Ribeiro, A. (1998) utilizou os conceitos da ECT em dois momentos da história do sistema agroindustrial da celulose no Brasil. Tais momentos, foram caracterizados por diferentes ambientes institucionais, como o período de estabelecimento da indústria de 
celulose no país e o momento atual, em que não vigoram mais os Incentivos Fiscais ao Reflorestamento (IFs).

A transação analisada foi o abastecimento da fábrica de celulose com madeira, num estudo de caso envolvendo a Cia. Suzano de Papel e Celulose. Testou-se a hipótese de que mesmo com o fim dos IFs, as características de especificidade do ativo, freqüência e incerteza levam a empresa a manter a estrutura de governança predominante hierárquica. A variável proxy utilizada para os custos de transação, foi o valor dos custos essencialmente burocráticos associados a cada estrutura de governança, a exemplo dos custos da alta gerência na grande corporação. Em relação à especificidade do ativo, buscou-se um indicador do valor da madeira na produção de celulose, capaz de refletir as principais especificidades da transação estudada (ativo dedicado, locacional e fisica). Tal indicador é fundamentalmente o custo da madeira na produção de celulose (US\$/kg de celulose). A especificidade da madeira deve aumentar a medida que se produz mais celulose por dólar invertido em madeira, portanto, pode ser representada pelo inverso do custo ( $\mathrm{kg}$ de celulose/US\$).

Os resultados encontrados demonstraram que a empresa escolheu as estruturas de governança mais adequadas, tanto no período de vigência dos IFs como ao final deste. Se por um lado, era interessante buscar uma estrutura $100 \%$ hierárquica enquanto havia IFs, atualmente, as estruturas de menor custo de transação são compostas $80 \%$ pela hierarquia.

Outras estruturas compostas em sua maioria pela hierarquia têm um desempenho semelhante entre si. Assim, pequenas variações na composição do abastecimento são esperadas em reação à mudança na legislação, porém, não estão previstas alterações que levem, por exemplo, à tercerização completa da base florestal. Este resultado corrobora a hipótese do trabalho de que mesmo com o fim dos IFs a estrutura de governança de menor custo de transação seria predominante hierárquica.

No Brasil, Mezzomo (1997) utilizou o ferramental teórico proposto pela ECT para analisar a coordenação no Sistema Agroindustrial das Olerícolas Congeladas (SAOC), baseado nas transações ocorridas nas principais interfaces tecnologicamente 
diferenciáveis. A primeira hipótese do trabalho, era de que a liderança no processamento estava associada a uma maior estrutura de ativos específicos sustentada por estruturas de governança mais complexas e a segunda hipótese dizia que a especificidade de ativos influenciava significativamente as estruturas de governança estabelecidas.

$\mathrm{O}$ estudo revelou que existem problemas em todos os atores no SAOC, reduzindo sua competitividade, mas o problema principal diz respeito aos investimentos específicos necessários para transacionar com o segmento varejista. Devido à reestruturação do segmento varejista, através das inovações gerenciais e tecnológicas, está se deslocando para o processador a responsabilidade com a logistica de distribuição e reposição de mercadoria. Com isso, aceitou-se a primeira hipótese, pois a empresa líder do segmento de processamento apresentava estes investimentos específicos dentro de uma estrutura de governança hierárquica.

No estudo das dimensões da transação, dois parâmetros relacionados com especificidade de ativos (especificidade humana e especificidade de assistência técnica) foram indutores de diferentes estruturas de governança. Dentre as variáveis que influenciaram significamente a estrutura de governança, ressaltou-se a importância do know-how exigido para condução das culturas, ou seja, culturas mais complexas em termos de conhecimento envolvido na sua condução demandam estruturas de governança também mais complexas para seu suporte.

As incertezas relacionadas às pragas e ao comportamento do preço de mercado também foram significantes. A susceptibilidade da cultura a ocorrência de insetos, ervas e problemas fitossanitários inibiu a emergência de estruturas de governança mistas, pois o aumento dos distúrbios exigiu uma maior adaptabilidade de tais estruturas, às induzindo estruturas de governança de mercado. Por outro lado, a existência de período de sazonalidade definido implicou em transações suportadas por estruturas mais simples, pois o preço baixo resultante da estrutura de mercado induziu a tipos de governança de mercado que conferiam maiores incentivos. A não incerteza sobre aspectos climáticos para os produtores foi a fonte de incerteza mais citada entre os entrevistados e não foi identificada como uma variável significativamente influente na estrutura de governança 
resultante. Isso evidenciou a necessidade de internalizar, nos contratos, salvaguardas que se antecipem a esses problemas de má adaptação.

Ohanian (1994) estudou a integração vertical de empresas produtoras de celulose com as de papel nos EUA, no período de 1900 a 1940. Partiu-se do pressuposto de que a integração vertical de empresas produtoras de celulose com as de papel estavam associadas positivamente com as variáveis explicativas que caracterizavam o custo de transação, freqüência e especificidade do ativo.

O grau de integração vertical das empresas foi utilizado como variável dependente. A proxy utilizada para o custo de transação foi a concentração dos mercados de celulose e papel nas diferentes regiões, ou seja, o pequeno número de ofertantes ou demandantes de celulose leva ao comportamento oportunístico dos agentes, elevando os custos de transação e, consequentemente, favorecendo a integração vertical. A freqüência da transação foi estimada pelo tamanho da planta industrial de papel, pois plantas maiores necessitam com mais frequeencia de celulose, possibilitando a integração vertical sem perdas de escala. Já a especificidade do ativo foi medida pelo tipo de papel a ser produzido. A produção de tipos especiais de papel exige uma composição específica de celulose favorecendo a integração vertical. Os resultados obtidos foram compativeis com o pressuposto formulado, confirmando o modelo.

Neves (1995) analisou o sistema agroindustrial citrícola brasileiro sob o enfoque da ECT e contratos, especificamente a transação entre produtores de frutas e indústrias processadoras. Essa transação pode-se dar de diversas formas, desde um extremo, onde está a simples compra direta sem nenhum tipo de arranjo contratual, até a produção integrada em outro extremo (integração vertical).

O problema foi analisar a alternativa de integração parcial via processamento por arrendamento de capacidade ociosa de indústria por processadores ou "toll processing", com base em variáveis de especificidade de ativos, frequêencia da transação e incerteza. A hipótese principal foi que o "toll processing" é uma alternativa eficiente.

Através de uma análise discreta comparada qualitativa foi confirmada a eficiência e estabilidade das relações de "toll processing" entre produtores e indústrias do 
setor, ou seja, de que está forma de coordenação mista foi uma solução eficiente sob a ótica da ECT.

Azevedo (1996) analisou as transação entre citriculturores e as indústrias de suco de laranja concentrado e congelado no Brasil, com o objetivo de avaliar a eficiência do arranjo institucional observado, ressaltando o papel da integração vertical parcial na barganha pelo excedente gerado por ativos específicos. Tratou-se de uma ilustração empírica das relações observadas teoricamente.

O trabalho caracterizou a dupla-face de eficiência e barganha na evolução do arranjo institucional no sistema agroindustrial citrícola. Para isso, foi analisada a evolução do contrato-padrão entre citricultores e indústria de sucos, procurando explicar alguns de seus fenômenos - como a integração vertical parcial para trás, o estabelecimento de cooperativas e o aumento de especificações no contrato.

Em relação a especificidade de ativo dedicado, esse foi se tornando cada vez mais específico na transação entre citricultor e empresa processadora devido ao crescimento da produção de laranja voltada à exportação de suco. Além da especificidade de ativo dedicado, a transação pelo insumo laranja foi marcada por duas outras fontes de dependência bilateral: especificidade fisica e temporal. A especificidade fisica foi observada pela valoração que a indústria dava a cada variedade de laranja nos contratos de compra e venda, em que as variedades próprias para processamento foram melhor remuneradas pelo preço acordado que as variedades apropriadas ao consumo de mesa. A especificidade temporal foi decorrente da perecibilidade da laranja e dos equipamentos da indústria.

O crescimento da especificidade de ativo dedicado ocasionou modificações no arranjo institucional que governava a transação entre citricultores $\mathrm{e}$ indústrias processadoras. Os elementos que foram incorporados aos contratos contribuiram para a redução dos custos conjuntos de transformação e de transação. No entanto, o movimento no sentido da integração vertical parcial foi mais adequadamente explicado por questões estratégicas e a forma organizacional observada não foi identificada como plenamente eficiente. 
Machado Filho (1997) buscou explicações do porquê em algumas situações a comercialização de animais no Brasil (gado) ocorre via leilões, e em outras situações não. Discutiu-se em quais situações os leilões surgiram como uma forma eficiente de governança, a partir dos condicionantes dados pelo ambiente institucional. Foram enfocadas as transações que ocorrem ao longo do Sistema Agroindustrial da Carne Bovina, em comparação com arranjos alternativos de governança, especialmente a venda direta no mercado "spot" e a venda direta através de outros arranjos contratuais. Dentro deste sistema se inserem as transações existentes no mercado de animais de raça, no mercado de animais de reposição e no mercado de animais terminados para abate.

Numa análise qualitativa, a pesquisa realizada apontou no sentido de que as características do ambiente institucional explicavam, em muitas situações, as escolhas alternativas das instituições de governança na comercialização de animais. Prevaleceram as formas mais eficientes no sentido de redução dos custos de transação. 


\section{METODOLOGIA}

\subsection{Tipo de pesquisa}

O presente trabalho foi dividido em duas etapas. Na primeira delas, foi realizada uma pesquisa de cunho descritivo, que procurou relatar situações de mercado a partir de dados primários, obtidos por meio de questionário ${ }^{10}$. Tratou-se de um estudo descritivo ou pesquisa quantitativa ${ }^{11}$. Quanto à dimensão da pesquisa no tempo, tratou-se de uma pesquisa ocasional $^{12}$.

Esta pesquisa focou e caracterizou as transações existentes entre produtores e quatro sistemas de distribuição atacadista de flores e plantas ornamentais, sob o enfoque da Economia dos Custos de Transação, determinando as estruturas de governança que prevalecem.

$\mathrm{Na}$ segunda etapa deste trabalho, sinalizou-se aspectos de eficiência e ineficiência dos sistemas de distribuição atacadista. Para isto, também foi realizada uma

\footnotetext{
${ }^{10} \mathrm{O}$ questionário possui questões abertas e fechadas. Segundo Kotler \& Armstrong (1993), questões fechadas incluem todas as respostas possiveis, e os entrevistados podem optar por aquelas que retratam sua realidade ou opinião. Questões abertas permitem aos entrevistados responder com suas próprias palavras e são com freqüência mais reveladoras que questões fechadas, uma vez que os entrevistados não ficam limitados em suas respostas.

${ }^{11}$ Para a realização de uma pesquisa quantitativa é necessário que o estudo seja realizado a partir da elaboração de amostras da população, utilizando-se a estatística para este fim. Os resultados da pesquisa serão analisados e interpretados a partir de médias e percentuais das respostas obtidas (Samara \& Barros, 1994).

${ }^{12}$ Pesquisa ocasional é aquela realizada uma única vez, sendo que os seus resultados mostram um instantânco do fenômeno estudado (Mattar, 1996).
} 
pesquisa de cunho descritivo, através de questionários. Quanto à dimensão da pesquisa no tempo, tratou-se de uma pesquisa ocasional.

\subsection{Elaboração do questionário}

De acordo com Cobra (1992), os procedimentos seguidos na elaboração do questionário podem ser apresentados em quatro etapas, sendo essas seguidas para orientar a formulação das questões que compõem o questionário utilizado na pesquisa de campo deste trabalho (apresentado no APÊNDICE 2).

Inicialmente, considera-se a construção do questionário. A formulação das questões deve ser feita com clareza e respeitando os objetivos do projeto de pesquisa.

A segunda etapa refere-se às decisões quanto à forma de resposta à pergunta, tipo de variáveis utilizadas e tipo de escala de medida. Na pesquisa de campo deste trabalho, utilizou-se um questionário com perguntas fechadas, abertas, semi-abertas, dicotômicas, encadeadas, com ordem de preferência e com escala de diferencial semântico. Foram utilizadas no questionário variáveis ${ }^{13}$ quantitativas e qualitativas.

Quanto ao tipo de escala de medida, foram empregadas escalas nominais, ordinais e razão. Segundo Tull \& Hawkins (1993), escalas nominais compreendem aquelas em que os números servem para categorizar objetos ou fatos e não há um sentido de ordenamento em seus itens. As escalas ordinais são aquelas em que os números, letras e outros símbolos servem para ordenar segundo um critério de comparação os itens. Já as escalas razão consiste na medição através dos números das variáveis estudadas, como volume de vendas, renda, preço, participação no mercado, etc.

A terceira etapa consiste no rascunho e pré-teste do questionário. $\mathrm{O}$ rascunho facilita a ordenação das idéias e a simplificação das questões e de sua apresentação, além

\footnotetext{
${ }^{13}$ Variáveis quantitativas são aquelas que descrevem quantidades e, desse modo, podem ser comparadas a conjuntos numéricos. Variáveis qualitativas são aquelas usadas para descrever qualidades, categorias, etc (Iemma, 1992).
} 
de clarear o significado e o propósito das indagações. A revisão criteriosa dos rascunhos ajuda a melhorar o questionário.

De outro lado, o pré-teste ajuda a eliminar dúvidas, a reformular as questões e, finalmente, a levar ao modelo definitivo do questionário.

No presente trabalho, realizou-se o pré-teste em pequena escala, facilitando a detecção de falhas e correções em tempo.

A quarta etapa consiste na revisão e redação da versão final do questionário. Neste trabalho, os resultados do pré-teste serviram para efetuar a revisão final do questionário.

As questões elaboradas para esta pesquisa foram divididas em três itens: A) Produtor (P); B) Sistema de Distribuição (SD) e C) Consumidor (C). O item A foi composto por 19 questões; o item B por 2 questões e o item C por 5 questões.

\subsection{Questões de pesquisa e especificação dos dados}

A primeira questão básica de pesquisa foi determinar as condições que caracterizam as transações existentes entre produtores e sistemas de distribuição de flores e plantas ornamentais e que resultam em estruturas de governança distintas. Para esta comparação entre estruturas de governança distintas com fatores teóricos determinantes desta estrutura, foi utilizado um critério de minimização de custos de transação.

Essas transações foram caracterizadas em termos de especificidade dos ativos, freqüência e incerteza.

Foram identificados os principais tipos de especificidade relacionados ao ativo flor nas transações entre produtores e sistemas de distribuição. Segundo Azevedo (1996), essa distinção entre os vários tipos de especificidade presta-se à análise empírica, mostrando as especificidades mais comuns e a forma como elas se materializam no mundo real. 
Conforme a classificação de Williamson (1996), descrita no capitulo 3, há três tipos de especificidade de ativo flor nas transações entre produtores e sistemas de distribuição:

a) fisicos: medido por componentes específicos utilizados para a produção de flores e plantas ornamentais e adotado pelo sistema de distribuição.

b) marca: medido por investimentos na marca própria.

c) humana: medido pela forma de capital humano específico empregado na produção.

Para medir os componentes específicos utilizados para a produção de flores e plantas ornamentais e adotado pelo sistema de distribuição, foram analisadas as respostas dadas às seguintes questões: P6, P12, P13, P14, que se referem, respectivamente, a tipo de estrutura existente no sistema de distribuição para manutenção da qualidade do produto (câmaras frias, pátio climatizado para o armazenamento, plataforma para o carregamento e descarregamento dos produtos, etc); utilização ou não de sistema coberto de produção e tipo utilizado (estufa simples, climatizada, semi-climatizada e/ou sombreamento); tipo de mudas e sementes utilizadas para a produção de flores e plantas ornamentais (produção própria e/ou comprada de empresas especializadas) e a utilização ou não de caminhão refrigerado para o transporte do produto da produção para o sistema de distribuição.

Para medir o investimento na marca própria, foi analisada a questão P15, que se refere ao investimento ou não na marca do produto e a forma de investimento (marca do produtor na embalagem, posters, folders, promoções, eventos, etc).

Para medir a forma de capital humano específico empregado na produção, foram analisadas as respostas dadas às seguintes questões: P9, P10 e P11, que se referem, respectivamente, ao tipo de assistência técnica responsável na produção (engenheiro agrônomo, técnico agrícola, fornecedor de insumos e/ou próprio produtor); existência de treinamento especializado para os funcionários de acordo com a espécie de flores $\mathrm{e}$ plantas ornamentais produzidas e a forma de treinamento (por espécie, função ou 
operação, etc) e pela facilidade ou não de substituição dos funcionários utilizados na produção.

Em relação à freqüência da transação, foi analisada a periodicidade semanal que ocorre a transação entre produtores e sistemas de distribuição (relativa a questão P16).

A incerteza foi analisada como aquela inerente à própria atividade e a proveniente do comportamento estratégico dos agentes. Para identificar a incerteza inerente à própria atividade, foram analisadas as respostas dadas às questões P12, P17, P18, que se referem, respectivamente, a utilização ou não de sistema coberto de produção e tipo utilizado (estufa simples, climatizada, semi-climatizada e/ou sombreamento), modo de controle de pragas e doenças pelos produtores (seqüencial ou conforme a necessidade) e a freqüência para os produtores que realizam o controle seqüencial (diariamente à quinzenalmente) e o maior risco associado à produção (padronização, clima, pragas e doenças, aquisição de insumos, todos ou nenhum). Para identificar a incerteza proveniente do comportamento estratégico dos agentes, foi analisada a resposta dada à questão P19, que se refere ao maior risco associado à venda dos produtos (inadimplência, demanda instável, preço, todos ou nenhum).

A segunda questão básica de pesquisa foi sinalizar aspectos de eficiência e ineficiência do sistema público tradicional (SPT1), sistema público tradicional com um mercado permanente de flores e plantas ornamentais (SPT2), sistema cooperativo (SC) e sistema privado (SPR). Para isso, foram estabelecidos os seguintes indicadores-chave:

1) faturamento do sistema de distribuição/tempo de comercialização;

2) faturamento do sistema de distribuição/hora-homem trabalhada;

3) tempo de ociosidade/homem no periodo de um dia;

4) faturamento do sistema de distribuição/área total;

5) contribuição do sistema de distribuição na manutenção da qualidade do produto;

6) grau de satisfação do consumidor;

7) tempo de carregamento gasto pelo consumidor no sistema de distribuição. 
Para o cálculo do indicador-chave 1, foram utilizadas as questões P2 e SD2, que se referem, respectivamente, ao tempo gasto com a comercialização e o faturamento de cada sistema de distribuição. Através dessas questões foram calculados o tempo gasto com a comercialização e o faturamento acumulado de cada sistema de janeíro a outubro de 1999, pois os dados sobre o faturamento foram fornecidos até essa data.

Para o cálculo do indicador-chave 2, foram utilizadas as questões P2, P3, P4 e $\mathrm{SD} 2$, que se referem, respectivamente, ao tempo gasto com a comercialização pelo sistema, número de homens envolvidos nesse período, tempo de trabalho de cada homem e o faturamento de cada sistema de distribuição.

$\mathrm{O}$ indicador-chave 3 foi calculado através das questões P2, P3 e P4, que se referem, respectivamente, ao tempo gasto com a comercialização pelo sistema, número de homens envolvidos nesse período e o tempo de trabalho de cada homem envolvido na comercialização.

O indicador-chave 4 foi calculado através das questões SD1 e SD2, que se referem, respectivamente, a área total utilizada para a comercialização e ao faturamento da cada sistema de distribuição. Para esse cálculo, também foi utilizado o faturamento acumulado de cada sistema de distribuição de janeiro a outubro de 1999.

Para avaliar o indicador-chave 5, foram utilizadas as questões P5 e P6, que se referem, respectivamente, a quantidade de vezes em que o produto é manuseado desde o descarregamento até o carregamento pelo cliente (de nenhuma a mais de 3 vezes) e ao tipo de estrutura existente no sistema de distribuição para manutenção da qualidade do produto (câmaras frias, pátio climatizado para o armazenamento, plataforma para o carregamento e descarregamento dos produtos, entre outras).

Para avaliar o indicador-chave 6 , foram utilizadas as questões $\mathrm{C} 1$ e $\mathrm{C} 2$, que se referem, respectivamente, a satisfação do consumidor em relação à qualidade do produto oferecido pelo sistema de distribuição (muito satisfeito, satisfeito, insatisfeito ou muito insatisfeito) e a coerência ou não entre o preço e a qualidade dos produtos oferecidos por cada sistema de distribuição e o motivo da não coerência (pouca qualidade, durabilidade, padronização, etc). 
$\mathrm{O}$ indicador-chave 7 foi avaliado através da questão $\mathrm{C} 4$, que se refere ao tempo gasto com o carregamento pelo consumidor, ou seja, qual é o tempo que o consumidor gasta entre a compra do produto e a saída do sistema de distribuição (de 0 a mais de 60 minutos).

As Tabelas 13 e 14 apresentadas a seguir, identificam as questões do questionário relacionadas as características das transações e aos indicadores-chave, que respondem aos objetivos propostos pela pesquisa.

Tabela 13. Questões relacionadas as características das transações.

\begin{tabular}{ll}
\hline Características das Transações & Questões $^{1}$ \\
\hline Especificidade do ativo & \\
Físicos & P6, P12, P13 e P14 \\
Marca & $\mathrm{P} 15$ \\
Humana & $\mathrm{P} 9, \mathrm{P} 10$ e P11 \\
Freqüência da transação & $\mathrm{P} 16$ \\
Incerteza & $\mathrm{P} 12, \mathrm{P} 17, \mathrm{P} 18$ e P19 \\
\hline
\end{tabular}

${ }^{1} \mathrm{P}$ : item $\mathrm{A}$ do questionário - questões aplicadas aos produtores 
Tabela 14. Questões relacionadas aos indicadores-chave.

\begin{tabular}{ll}
\hline Indicadores-Chave & \multicolumn{1}{c}{ Questões $^{1}$} \\
\hline 1) Faturamento do sistema de distribuição/tempo de & P2 e SD2 \\
comercialização & \\
$\begin{array}{ll}\text { 2) Faturamento do sistema de distribuição/hora-homem } \\
\text { trabalhada }\end{array}$ & P2, P3, P4 e SD2 \\
3) Tempo de ociosidade/homem no período de um dia & P2, P3 e P4 \\
4) Faturamento do sistema de distribuição/área total & SD1 e SD2 \\
5) Contribuição do sistema de distribuição na manutenção & \\
da qualidade do produto & P5 e P6 \\
6) Grau de satisfação do consumidor & $\mathrm{C} 1$ e C2 \\
7) Tempo de carregamento gasto pelo consumidor & $\mathrm{C} 4$ \\
\hline
\end{tabular}

${ }^{1} \mathrm{P}$ : item A do questionário - questões aplicadas aos produtores

SD: item B do questionário - questões aplicadas ao sistema de distribuição

$\mathrm{C}$ : item $\mathrm{C}$ do questionário - questões aplicadas aos consumidores

\subsection{Amostragem}

O questionário utilizado para analisar as transações entre produtores e os sistemas de distribuição e sinalizar aspectos de eficiência e ineficiência desses sistemas foi aplicado aos produtores, funcionários dos sistemas de distribuição e consumidores ${ }^{14}$ de flores e plantas ornamentais do Estado de São Paulo, pois atualmente a floricultura paulista se destaca ocupando cerca de $60 \%$ do mercado nacional.

Os sistemas de distribuição analisados foram: CEAGESP (SPT1), CEASA Campinas (SPT2), Veiling Holambra (SC) e FLORANET (SPR). Os três primeiros foram escolhidos por serem responsáveis por $82 \%$ do total de flores e plantas ornamentais

\footnotetext{
${ }^{14} \mathrm{O}$ consumidor, dependendo do sistema de distribuição, pode ser o atacadista, varejista ou até mesmo o consumidor final.
} 
comercializadas no Estado de São Paulo (Arruda et al., 1996). Já o SPR foi recentemente implantado, mas apresenta crescente participação no total de volume comercializado. Os produtores e consumidores entrevistados vendiam e compravam flores e plantas ornamentais nesses sistemas de distribuição.

No SPT1 e no SPT2, os produtores foram entrevistados utilizando-se o item A; os funcionários o item $\mathrm{B}$ e os consumidores o item $\mathrm{C}$ do questionário (como pode ser verificado no APENNDICE 2).

Já para o SC e o SPR, parte do item A (questões 2, 3, 4, 5 e 6) foi respondida pelo responsável do setor de logística, pois a comercialização é intermediada por esses sistemas de distribuição e não pelos produtores, como ocorre no SPT1 e SPT2. As demais questões do item $\mathrm{A}$ e os itens $\mathrm{B}$ e $\mathrm{C}$, foram aplicadas da mesma maneira que no SPT1 e SPT2.

Para o dimensionamento do tamanho da amostra foi utilizada a técnica amostral probabilística aleatória simples ${ }^{15}$. De acordo com Kotler \& Armstrong (1993), Mattar (1996) e Samara \& Barros (1994), qualquer discussão técnica sobre as vantagens e desvantagens de amostras probabilísticas e não probabilísticas ${ }^{16}$ claramente evidenciará as vantagens da primeira. A característica de conhecer a probabilidade de cada elemento da população fazer parte da amostra garante que a amostra será constituída de elementos selecionados objetivamente por processos aleatórios e não pela vontade do pesquisador. Este fato, em termos estatísticos, significa que a amostragem probabilística permite calcular em que medida os valores de variáveis obtidos nas amostras diferem dos valores da população. Essa diferença é o erro amostral e advém do fato de estarem sendo tomadas medidas numa amostra e não em toda população.

\footnotetext{
15 Amostragem aleatória simples caracteriza-se pelo fato de cada elemento da população ter probabilidade conhecida, diferente de zero, e idêntica à dos outros elementos, de ser selecionado para fazer parte da amostra (Mattar, 1996). ${ }^{15}$ Amostras não-probabilísticas são selecionadas por critérios subjetivos do pesquisador, de acordo com sua experiência e com objetivos do estudo e não são obtidas utilizando-se conceitos estatísticos (Samara \& Barros, 1994).

${ }^{16}$ Amostras não-probabilísticas são selecionadas por critérios subjetivos do pesquisador, de acordo com sua experiência e com objetivos do estudo e não são obtidas utilizando-se conceitos estatísticos (Samara \& Barros, 1994).
} 
Segundo Samara \& Barros (1994), a amostra probabilística aleatória simples é a técnica mais perfeita para se obter uma amostra representativa da população, quando a população não é muito grande. Portanto, não havia necessidade de utilizar as demais técnicas de amostragem probabilística (estratificada $^{17}$, sistemática $^{18}$ e por conglomerado ${ }^{19}$ ).

O questionário foi inicialmente aplicado a alguns produtores e consumidores de cada sistema de distribuição e a partir dos dados gerados nessas entrevistas calculou-se o tamanho mínimo da amostra (Tabela 15). Para esse calculo foi utilizada a metodologia citada em Mattar (1996), relacionada a amostragem aleatória simples.

$\mathrm{O}$ cálculo amostral foi realizado através de questões numéricas usando a form. (1) e para os itens do questionário que não continham esse tipo de questão, foram utilizadas as questões dicotômicas usando as form. (2) e (3). A questão que produziu o maior tamanho de amostra foi a adotada como referência, para assegurar que os dados fossem estimados com a precisão estatística desejada.

A questão numérica adotada como referência foi a P2 (item A do questionário) e as questões dicotômicas foram a P12 (item A do questionário) e C2 (item C do questionário).

Calculou-se o tamanho mínimo da amostra de produtores e consumidores, adotando um nível de confiabilidade de $95 \%$ (form. (1), (2) e (3)) e erro máximo de 0,5 hora para a questão numérica e 5\% para as questões dicotômicas.

\footnotetext{
${ }^{17}$ Como citado por Scheaffer et al. (1986), a técnica de amostragem probabilística estratificada deve ser utilizada quando se deseja subdividir a população em extratos homogêneos. A população é dividida em grupos mutuamente exclusivos (como estudantes), retirando-se amostras aleatórias de cada um desses grupos.

${ }_{18}$ Como citado por Scheaffer et al. (1986), na técnica de amostragem probabilística sistemática os elementos da amostra (n) são selecionados aleatoriamente e será estabelecido um intervalo para a aplicação do questionário entre esses elementos.

${ }^{19}$ Como citado por Samara \& Barros (1994), a técnica de amostragem probabilística por conglomerado exige a utilização de mapas detalhados de regiões, estados e cidades, pois, para seleção da amostra, há subdivisão da área a ser pesquisada por bairros, quarteirões e domicílios, que serão sorteados para composição dos elementos da amostra, e a pesquisa será realizada de forma sistemática para que não haja interferências nas informações.
} 


$$
n=\frac{N 4 S^{2}}{e^{2}(N-1)+4 S^{2}}
$$

população finita:

$$
n=\frac{N 4 P Q}{e^{2}(N-1)+4 P Q}
$$

população infinita:

$$
n=\frac{4 P Q}{e^{2}}
$$

sendo:

$$
\begin{aligned}
n & =\text { número de elementos da amostra a ser pesquisada } \\
S^{2} & =\text { variância da amostra-piloto, estimadora da variância da população } \\
e & =\text { precisão da amostra ou erro máximo admitido } \\
N & =\text { número de elementos da população (população finita) } \\
P & =\text { proporção de ocorrência da variável em estudo na população } \\
Q & =\text { proporção de não-ocorrência da variável em estudo na população; sendo } P+Q=1
\end{aligned}
$$

A Tabela 15 mostra o tamanho da população e o tamanho mínimo da amostra calculada para o nível de confiabilidade e erro máximo adotado.

Tabela 15. Tamanho da população, tamanho mínimo da amostra, nivel de confiabilidade e erro máximo adotado.

\begin{tabular}{lcccccccc}
\hline Sistema de & \multicolumn{3}{c}{ PRODUTORES } & & \multicolumn{4}{c}{$-\cdots$} \\
Distribuição & $N^{1}$ & $n^{2}$ & $e^{3}$ & $N C^{4}$ & $N$ & $n$ & $e$ & $N C$ \\
\hline SPT1 & 1.040 & 45 & 0,5 hora & $95 \%$ & 5 & 76 & $5 \%$ & $95 \%$ \\
SPT2 & 238 & 41 & 0,5 hora & $95 \%$ & 3.721 & 139 & $5 \%$ & $95 \%$ \\
SC & 162 & 91 & $5 \%$ & $95 \%$ & 295 & 97 & $5 \%$ & $95 \%$ \\
SPR & 8 & 4 & $5 \%$ & $95 \%$ & 120 & 66 & $5 \%$ & $95 \%$ \\
\hline
\end{tabular}

${ }^{1} N$ : tamanho da população

${ }^{2} n$ : tamanho da amostra

${ }^{3} e$ : erro máximo adotado

${ }^{4} N C$ : nivel de confiabilidade

${ }^{5}$ Não existe um cadastro de clientes 
O tamanho da amostra entrevistada dos produtores do SPT1, SPT2 e SPR atingiu o mínimo programado. Já para os produtores do SC e consumidores dos quatro sistemas de distribuição, entrevistou-se um número menor de indivíduos que o programado para o nível de precisão estatística adotado. Isso ocorreu devido a limitação de tempo e recursos financeiros necessários para realização de outras entrevistas.

Segundo Mattar (1996), não se deve aceitar passivamente, sem maiores considerações, o tamanho da amostra gerado por uma fórmula estatística. Inúmeros outros fatores precisam ser levados em conta, como a restrição de tempo, custo, objetivos da pesquisa, entre outros.

A Tabela 16 abaixo mostra o tamanho da população e da amostra entrevistada. Para essa amostra de produtores e consumidores estão relacionados os erros máximos atingidos e o nivel de confiabilidade adotado.

Tabela 16. Tamanho da população e da amostra entrevistada, erro e nível de confiabilidade.

\begin{tabular}{|c|c|c|c|c|c|c|c|c|}
\hline \multirow{2}{*}{$\begin{array}{l}\text { Sistema de } \\
\text { Distribuição }\end{array}$} & \multicolumn{4}{|c|}{--- PRODUTORES ------ } & \multicolumn{4}{|c|}{---- CONSUMIDORES --- } \\
\hline & $N^{1}$ & $n^{2}$ & $e^{3}$ & $N C^{4}$ & $N$ & $n$ & $e$ & $N C$ \\
\hline SPT1 & 1.040 & 46 & 0,465 hora & $95 \%$ & 5 & 46 & $15 \%$ & $95 \%$ \\
\hline SPT2 & 238 & 42 & 0,425 hora & $95 \%$ & 3.721 & 41 & $13 \%$ & $95 \%$ \\
\hline SC & 162 & 31 & $8 \%$ & $95 \%$ & 295 & 37 & $12 \%$ & $95 \%$ \\
\hline SPR & 8 & 4 & $5 \%$ & $95 \%$ & 120 & 19 & $15 \%$ & $95 \%$ \\
\hline
\end{tabular}

${ }^{1} N$ : tamanho da população

${ }^{2} n$ : tamanho da amostra

${ }^{3} e$ : erro máximo

${ }^{4} N C$ : nivel de confiabilidade

${ }^{5}$ Não existe um cadastro de clientes 


\subsection{Método de análise dos dados}

Para fundamentar a análise dos dados obtidos através do questionário foi utilizada a técnica de estatística descritiva.

As variáveis relacionadas às características das transações entre produtores e sistemas de distribuição foram qualitativas e o tipo de escala usado para medição das variáveis foi nominal. Para medir essas variáveis foi utilizada a distribuição de freqüência (absoluta e relativa), já que esta é a única medida em métodos descritivos que pode ser aplicada à variável nominal.

A estrutura de governança predominante (mercado, híbrida ou hierárquica) em termos de redução de custos de transação, variou em função da especificidade dos ativos (Figura 8). Embora as variáveis de incerteza e freqüência sejam altamente relevantes, a variável relacionada com a especificidade do ativo foi o único atributo considerado.

Os ativos foram classificados em não-específicos (especificidade baixa) e específicos (especificidade alta) de acordo com o contraste das distribuições de frequiência das variáveis qualitativas. Quando não houve um contraste relevante da distribuição de freqüência da variável analisada, essa não foi utilizada para explicar o grau de especificidade do ativo. Tratou-se portanto de uma análise discreta comparada.

A análise do contraste das distribuições de frequêencia nas variáveis qualitativas é um tipo de procedimento que pode deixar a desejar no que se refere à análise de significância dos resultados, já que não foram realizadas inferências estatísticas. No entanto, dada a dificuldade e subjetividade em mensurar os custos e atributos das transações entre produtores e sistemas de distribuição de flores e plantas ornamentais, essa ferramenta tornou-se útil na prescrição das estruturas de governança que prevalecem.

Os ativos físicos foram classificados como específicos nas transações em que os produtores apresentaram elevada freqüência na utilização de estufas climatizadas e/ou semi-climatizadas, na compra de mudas e sementes de empresas especializadas e no transporte do produto em caminhão refrigerado e aonde os sistemas de distribuição 
investiram mais em estruturas específicas para manutenção da qualidade do produto. Para os produtores e sistemas de distribuição que apresentaram uma menor freqüência nas variáveis mencionadas, os ativos físicos foram classificados como não-específicos.

Para os ativos marca, a especificidade alta foi relacionada à elevada freqüencia de investimento na marca do produto.

Os ativos humano foram classificados como específicos nas transações em que os produtores apresentaram elevada freqüência na utilização de assistência técnica especializada na produção e no treinamento especializado dos funcionários e baixa freqüência na substitubilidade dos funcionários empregados na produção.

$\mathrm{Na}$ análise das variáveis referentes aos indicadores-chave também foi utilizada a técnica de estatística descritiva. As variáveis relacionadas aos indicadores-chave foram qualitativas e quantitativas e os tipos de escala usados para medição das variáveis foram nominal, ordinal e razão.

Para medir as variáveis qualitativas nominal e ordinal, também foi utilizada a distribuição de freqüência (absoluta e relativa).

Já as variáveis quantitativas (razão) foram utilizadas para o cálculo dos indicadores-chave 1, 2 e 3. Para medir essas variáveis foram utilizadas médias (form. (4)), variâncias (form. (5)), e desvios-padrão (form. (6)), para indicar alguma variabilidade existente na amostra. Os resultados podem ser observados na Tabela 67 (APÊNDICE 1).

Média: $\quad \bar{x}=\frac{\sum_{i=1}^{n} x_{i}}{n}$

Variância:

$$
S^{2}=\frac{\sum\left(x_{i}-\bar{x}\right)^{2}}{n-1}
$$

Desvio-padrão:

$$
S=\sqrt{\frac{\sum\left(x_{i}-\bar{x}\right)^{2}}{n-1}}
$$

$x_{i}=$ observação

$n$ = número de elementos da amostra pesquisada 
A forma adotada para sinalizar em quais aspectos um determinado sistema de distribuição é mais eficiente que os demais foi a comparação de valores e frequiências para cada indicador-chave.

Os sistemas de distribuição que apresentaram maiores valores para os indicadores-chave 1,2 e 4 e o menor valor para o indicador-chave 3 foram os mais eficientes que os demais nesses aspectos. Para o indicador-chave 5, o sistema de distribuição que apresentou a menor frequência de manuseio do produto e que investiu mais em estruturas específicas para manutenção da qualidade das flores e plantas ornamentais foi o mais eficiente. No indicador-chave 6 , a maior freqüência em relação a satisfação do consumidor e a coerência entre preço e qualidade indicou elevada eficiência. Para o indicador-chave 7, o sistema de distribuição que apresentou a menor freqüencia em relação ao tempo gasto com o carregamento pelo consumidor foi o mais eficiente. 


\section{RESULTADOS E DISCUSSÃO}

\subsection{Características da transação}

Através das características das transações entre produtores e quatro sistemas de distribuição de flores e plantas ornamentais do Estado de São Paulo, foi mostrado como se deu a escolha das estruturas de governança que prevalecem.

\subsubsection{Especificidade dos Ativos}

Os ativos foram classificados em 2 classes: não-específicos (especificidade baixa) e especificos (especificidade alta). Os principais tipos de especificidade relacionados ao ativo flor foram fisicos, marca e humano.

A especificidade de ativos físicos foi medida por componentes específicos utilizados pelos produtores para a produção de flores e plantas ornamentais, como a utilização de sistema coberto de produção, mudas e sementes compradas de empresas especializadas, transporte do produto realizado em caminhão refrigerado e a existência de estruturas específicas nos sistemas de distribuição que contribuiam na manutenção da qualidade e durabilidade do produto. Os resultados estão apresentados nas Tabelas 17, 18 e 19 e Figura 9. 
Tabela 17. Utilização de sistema coberto de produção pelos produtores.

\begin{tabular}{lcccccccc}
\hline & \multicolumn{2}{c}{ SPT1 } & \multicolumn{2}{c}{ SPT2 } & \multicolumn{2}{c}{ SC } & \multicolumn{2}{c}{ SPR } \\
Alternativa & $f^{1}$ & $\%$ & $f$ & $\%$ & $f$ & $\%$ & $f$ & $\%$ \\
\hline Sim & 39 & 84,8 & 37 & 88,1 & 29 & 93,5 & 4 & 100,0 \\
Não & 7 & 15,2 & 5 & 11,9 & 2 & 6,5 & 0 & 0,0 \\
\hline \hline Total & 46 & 100,0 & 42 & 100,0 & 31 & 100,0 & 4 & 100,0 \\
\hline
\end{tabular}

Fonte: Dados da pesquisa

${ }^{1}$ Freqüência de respostas

Tabela 18. Tipo de sistema coberto de produção utilizado pelos produtores.

\begin{tabular}{lcccccccc}
\hline & \multicolumn{2}{c}{ SPT1 } & \multicolumn{2}{c}{ SPT2 } & \multicolumn{2}{c}{ SC } & \multicolumn{2}{c}{ SPR } \\
Alternativa & $f$ & $\%^{2}$ & $f$ & $\%^{2}$ & $f$ & $\%^{2}$ & $f$ & $\%^{2}$ \\
\hline Cobertura (estufa simples) & 21 & 53,8 & 26 & 96,3 & 9 & 31,0 & 1 & 25,0 \\
Estufa climatizada & 4 & 10,3 & 3 & 8,1 & 16 & 55,2 & 1 & 25,0 \\
Estufa semi-climatizada & 0 & 0,0 & 0 & 0,0 & 5 & 17,2 & 2 & 50,0 \\
Sombreamento & 0 & 0,0 & 1 & 2,7 & 0 & 0,0 & 0 & 0 \\
Cobertura e campo & 16 & 41,0 & 11 & 29,7 & 0 & 0,0 & 0 & 0 \\
\hline Total de respostas (1) & 41 & 105,1 & 41 & 136,8 & 30 & 103,4 & 4 & 100,0 \\
Total de entrevistas (2) & 39 & 100,0 & 37 & 100,0 & 29 & 100,0 & 4 & 100,0 \\
\hline
\end{tabular}

Fonte: Dados da pesquisa

${ }^{1}$ Média de respostas por entrevistados $\mathrm{SPT} 1=1,1$.

'Média de respostas por entrevistados SPT2 $=1,1$.

${ }^{1}$ Média de respostas por entrevistados $\mathrm{SC}=1,03$.

${ }^{1}$ Média de respostas por entrevistados $\mathrm{SPR}=1,0$.

${ }^{2} \mathrm{~A}$ porcentagem das alternativas é feita tendo por base o total de respostas.

Tabela 19. Origem das mudas e sementes utilizadas pelos produtores.

\begin{tabular}{lcccccccc}
\hline & \multicolumn{2}{c}{ SPT1 } & \multicolumn{2}{c}{ SPT2 } & \multicolumn{2}{c}{ SC } & \multicolumn{2}{c}{ SPR } \\
Alternativa & $f$ & $\%$ & $f$ & $\%$ & $f$ & $\%$ & $f$ & $\%$ \\
\hline Produção própria & 12 & 26,1 & 12 & 28,6 & 8 & 25,8 & 1 & 25,0 \\
Compradas de empresas especializadas & 8 & 17,4 & 11 & 26,2 & 10 & 32,3 & 2 & 50,0 \\
Ambos & 26 & 56,5 & 19 & 45,2 & 13 & 41,9 & 1 & 25,0 \\
\hline \hline Total & 46 & 100,0 & 42 & 100,0 & 31 & 100,0 & 4 & 100,0 \\
\hline
\end{tabular}

Fonte: Dados da pesquisa. 


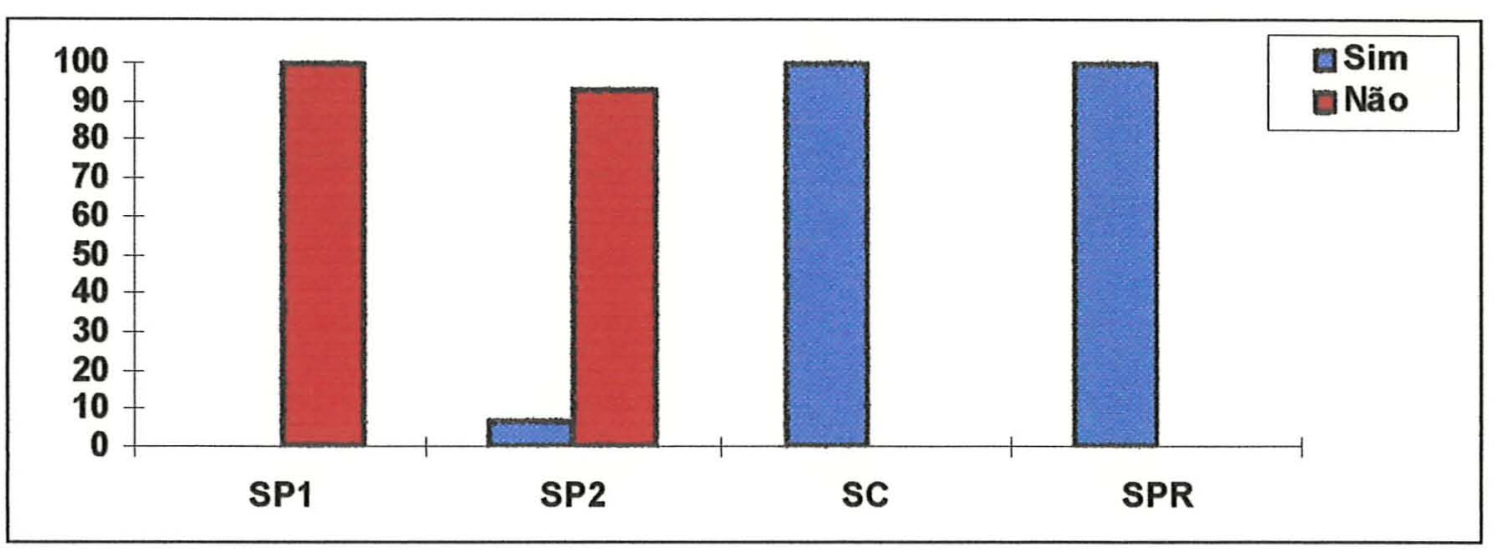

Figura 9- Transporte do produto realizado em caminhão refrigerado.

Fonte: Dados da pesquisa.

A maioria dos produtores utiliza sistema coberto de produção (Tabela 17). No entanto, $55,2 \%$ e $25,0 \%$ dos produtores entrevistados que distribuem via SC e SPR respectivamente, utilizam estufas climatizadas e $17,2 \%$ e $50 \%$ estufas semi-climatizadas, enquanto que $53,8 \%$ e $96,3 \%$ dos produtores entrevistados que distribuem via SPT1 e SPT2 respectivamente, utilizam estufas simples (como pode ser observado na Tabela 18). Existe um maior montante de capital, consequentemente risco envolvido, em utilizar estufas climatizadas ou semi-climatizadas quando comparadas às estufas simples.

Outro componente específico utilizado pelos produtores para a produção de flores e plantas ornamentais é a compra de mudas e sementes de empresas especializadas, que apresentam maior qualidade e são livres de pragas e doenças, resultando em um produto final de melhor qualidade e durabilidade. Atualmente, muitos produtores acham mais caro comprar mudas e sementes de empresas especializadas e acabam produzindo-as na própria propriedade.

Em geral, os produtores estão investindo na compra de mudas e sementes de empresas especializadas (Tabela 19). Observa-se que 17,4\%, 26,2\%, 32,3\% e $50 \%$ dos produtores que distribuem via SPT1, SPT2, SC e SPR respectivamente, compram suas mudas e sementes somente de empresas especializadas. Uma grande parte dos produtores que distribuem via SPT1, SPT2, SC e SPR (56,5\%, 45,2\%, 41,9\% e 25,0\% dos 
entrevistados respectivamente) produzem e compram de empresas especializadas suas mudas e sementes.

O transporte das flores e plantas ornamentais em caminhões refrigerados das propriedades rurais para os sistemas de distribuição, é um outro componente específico utilizado pelos produtores que contribui para manutenção da qualidade dos produtos.

Analisando a Figura 9, verifica-se que todo o transporte do produto da propriedade para o SC e SPR é realizado em caminhões refrigerados, pois os produtores contratam empresas especializadas em transportar produtos perecíveis (tercerização). $\mathrm{O}$ transporte para o SPT1 não ocorre em caminhão refrigerado. Para o SPT2, apenas 7,1\% dos entrevistados realizam o transporte em caminhão refrigerado.

A especificidade de ativos físicos também foi medida pela existência de estruturas específicas para flores e plantas ornamentais nos sistemas de distribuição, que contribuíam na manutenção da qualidade e durabilidade do produto.

$\mathrm{O}$ SC investe em câmaras frias e pátio climatizado para o armazenamento e plataforma para o carregamento e descarregamento dos produtos. O SPR também investe em câmaras frias, plataforma para o carregamento e descarregamento e em laboratório de análise de pós-colheita, para avaliação física e fisiológica do produto. No SPT1 e SPT2 não existe nenhuma estrutura específica para manutenção da qualidade do produto. Além disso, a Praça da Batata, Cebola e Flores (PBCF) do SPT1 não é coberta. Nos dias em que a comercialização ocorre neste local, o produto fica exposto, perdendo em qualidade.

Para os produtores que distribuem via SC e SPR a especificidade de ativos físicos foi considerada alta, decorrente dos investimentos em componentes específicos (como a utilização de estufas climatizadas e semi-climatizadas, mudas e sementes compradas de empresas especializadas e transporte do produto realizado em caminhão refrigerado) e que têm baixo valor em usos alternativos. O SC e o SPR também apresentam especificidade de ativos fisicos alta, quando analisados os investimentos realizados em estruturas específicas para manutenção da qualidade e durabilidade do produto.

Já os produtores que distribuem via SPT1 e SPT2 investem menos em componentes especificos utilizados para a produção de flores e plantas ornamentais. 
Nesses sistemas não existem estruturas específicas que contribuam para manutenção da qualidade e durabilidade do produto. Nesses casos, os ativos fisicos foram classificados como não-específicos.

A especificidade de ativos marca foi medida através de investimentos na marca do produto pelos produtores que distribuem via SPT1, SPT2, SC e SPR. Os resultados estão apresentados nas Tabelas 20 e 21 abaixo:

Tabela 20. Investimento na marca do produto pelos produtores.

\begin{tabular}{lcccccccc}
\hline & \multicolumn{2}{c}{ SPT1 } & \multicolumn{2}{c}{ SPT2 } & \multicolumn{2}{c}{ SC } & \multicolumn{2}{c}{ SPR } \\
Alternativa & $f$ & $\%$ & $f$ & $\%$ & $f$ & $\%$ & $f$ & $\%$ \\
\hline Sim & 8 & 17,4 & 9 & 21,4 & 25 & 80,6 & 4 & 100,0 \\
Não & 38 & 82,6 & 33 & 78,6 & 6 & 19,4 & 0 & 0,0 \\
\hline \hline Total & 46 & 100,0 & 42 & 100,0 & 31 & 100,0 & 4 & 100,0 \\
\hline
\end{tabular}

Fonte: Dados da pesquisa

Tabela 21. Forma de investimento na marca do produto pelos produtores.

\begin{tabular}{lcccccccc}
\hline & \multicolumn{2}{c}{ SPT1 } & \multicolumn{2}{c}{ SPT2 } & \multicolumn{2}{c}{ SC } & \multicolumn{2}{c}{ SPR } \\
Alternativa & $f$ & $\%^{2}$ & $f$ & $\%^{2}$ & $f$ & $\%^{2}$ & $f$ & $\%^{2}$ \\
\hline Marca do produtor na embalagem & 8 & 100,0 & 9 & 100,0 & 20 & 80,0 & 4 & 100,0 \\
Promoções & 1 & 12,5 & 1 & 11,1 & 2 & 8,0 & 0 & 0,0 \\
Eventos (feiras) & 0 & 0,0 & 1 & 11,1 & 2 & 8,0 & 1 & 25,0 \\
Outros (posters, folders, etc) & 0 & 0,0 & 0 & 0,0 & 3 & 12,0 & 0 & 0,0 \\
\hline Total de respostas (1) & 9 & 112,5 & 11 & 122,2 & 27 & 108,0 & 5 & 125,0 \\
Total de entrevistas (2) & 8 & 100,0 & 9 & 100,0 & 25 & 100,0 & 4 & 100,0 \\
\hline
\end{tabular}

Fonte: Dados da pesquisa

${ }^{1}$ Média de respostas por entrevistados SPT1 $=1,1$.

${ }^{1}$ Média de respostas por entrevistados $\mathrm{SPT} 2=1,2$.

${ }^{1}$ Média de respostas por entrevistados $S C=1,1$.

${ }^{1}$ Média de respostas por entrevistados $\mathrm{SPR}=1,3$.

${ }^{2} \mathrm{~A}$ porcentagem das alternativas é feita tendo por base o total de respostas.

A análise da Tabela 20 demonstra que $80,6 \%$ e $100 \%$ dos produtores que distribuem via SC e SPR respectivamente, investem na marca de seus produtos. Esse investimento é realizado pela maioria dos produtores colocando sua marca na embalagem (Tabela 21). Além da marca, é comum a embalagem conter informações sobre o nome do produtor, endereço, data de embalamento, classificação do produto (desde que tenha sido 
classificado de acordo com normas específicas) e condições de conservação (temperatura máxima e mínima e método de preservar o produto).

Outras formas de investimento na marca, utilizadas pelos produtores que distribuem via SC, são a utilização de posters e folders. Já os produtores que distribuem via SPR investem em eventos.

No SPT1 e SPT2 apenas 17,4 e $21,4 \%$ dos produtores entrevistados investem na marca de seus produtos, sendo a principal forma de investimento a marca do produtor na embalagem.

Através dos resultados apresentados na Tabela 20, verifica-se que os produtores que distribuem via SC e SPR investem mais capital na marca de seus produtos quando comparado aos produtores que distribuem via SPT1 e SPT2, caracterizado como uma maior especificidade dos ativos.

A especificidade de ativos humano foi medida pela forma de capital humano responsável pela assistência técnica na produção, pelo treinamento especializado dos funcionários para a produção de flores e plantas ornamentais e pela facilidade ou não de substituição dos funcionários empregados na produção. Os resultados estão apresentados nas Tabelas 22, 23, 24 e 25 .

Tabela 22. Forma de capital humano responsável pela assistência técnica na produção.

\begin{tabular}{lcccccccc}
\hline & \multicolumn{2}{c}{ SPT1 } & \multicolumn{2}{c}{ SPT2 } & \multicolumn{2}{c}{ SC } & \multicolumn{2}{c}{ SPR } \\
Alternativa & $f$ & $\%$ & $f$ & $\%$ & $f$ & $\%$ & $f$ & $\%$ \\
\hline Engenheiro agrônomo & 9 & 19,5 & 9 & 21,4 & 10 & 32,3 & 0 & 0,0 \\
Técnico agrícola & 1 & 2,2 & 0 & 0,0 & 9 & 29,0 & 0 & 0,0 \\
Fornecedor de insumos & 1 & 2,2 & 0 & 0,0 & 0 & 0,0 & 0 & 0,0 \\
Próprio produtor & 35 & 76,1 & 33 & 78,6 & 12 & 38,7 & 4 & 100,0 \\
\hline Total & 46 & 100,0 & 42 & 100,0 & 31 & 100,0 & 4 & 100,0 \\
\hline
\end{tabular}

Fonte: Dados da pesquisa 
Tabela 23. Treinamento especializado dos funcionários para a produção flores e plantas ornamentais.

\begin{tabular}{lcccccccc}
\hline & \multicolumn{2}{c}{ SPT1 } & \multicolumn{2}{c}{ SPT2 } & \multicolumn{2}{c}{ SC } & \multicolumn{2}{c}{ SPR } \\
Alternativa & $f$ & $\%$ & $f$ & $\%$ & $f$ & $\%$ & $f$ & $\%$ \\
\hline Sim & 19 & 41,3 & 6 & 14,3 & 18 & 58,1 & 3 & 75,0 \\
Não & 27 & 58,7 & 36 & 85,7 & 13 & 41,9 & 1 & 25,0 \\
\hline \hline Total & 46 & 100,0 & 42 & 100,0 & 31 & 100,0 & 4 & 100,0 \\
\hline
\end{tabular}

Fonte: Dados da pesquisa

Tabela 24. Formas de treinamento especializado para os funcionários.

\begin{tabular}{lcccccccc}
\hline & \multicolumn{2}{c}{ SPT1 } & \multicolumn{2}{c}{ SPT2 } & \multicolumn{2}{c}{ SC } & \multicolumn{2}{c}{ SPR } \\
Alternativa & $f$ & $\%$ & $f$ & $\%$ & $f$ & $\%$ & $f$ & $\%$ \\
\hline Por espécie & 14 & 73,7 & 1 & 16,7 & 2 & 11,1 & 1 & 33,3 \\
Função/operação & 4 & 21,1 & 5 & 83,3 & 2 & 11,1 & 0 & 0,0 \\
Outros & 1 & 5,3 & 0 & 0,0 & 14 & 77,8 & 2 & 66,7 \\
\hline \hline Total & 19 & 100,0 & 6 & 100,0 & 18 & 100,0 & 4 & 100,0 \\
\hline
\end{tabular}

Fonte: Dados da pesquisa

Tabela 25. Facilidade de substituição dos funcionários utilizados na produção.

\begin{tabular}{lcccccccc}
\hline & \multicolumn{2}{c}{ SPT1 } & \multicolumn{2}{c}{ SPT2 } & \multicolumn{2}{c}{ SC } & \multicolumn{2}{c}{ SPR } \\
Alternativa & $f$ & $\%$ & $f$ & $\%$ & $f$ & $\%$ & $f$ & $\%$ \\
\hline Sim & 16 & 34,8 & 16 & 38,1 & 15 & 48,4 & 1 & 25,0 \\
Não & 30 & 65,2 & 26 & 61,9 & 16 & 51,6 & 3 & 75,0 \\
\hline Total & 46 & 100,0 & 42 & 100,0 & 31 & 100 & 4 & 100,0 \\
\hline
\end{tabular}

Fonte: Dados da pesquisa

Analisando a Tabela 22, observa-se que os produtores que distribuem via SC são os que mais investem em funcionários com maior nível técnico para a produção de flores e plantas ornamentais, pois $32,3 \%$ dos produtores utilizam engenheiros agrônomos e $29,0 \%$ utilizam técnicos agrícolas.

Os produtores que distribuem pelo SPR são os responsáveis pela assistência técnica na produção. Geralmente investem em seu capital humano, através de cursos de 
especialização e viagens técnicas para a Holambra, o maior centro de tecnologia para a produção de flores e plantas ornamentais.

Os produtores que distribuem pelo SPT1 e SPT2 também são os responsáveis pela assistência técnica na produção ( 76,1 e $78,6 \%$ dos entrevistados respectivamente). A maioria dos produtores entrevistados não investe em capital humano, ressaltando o conhecimento adquirido na produção.

Outra forma utilizada para medir a especificidade de ativo humano foi a existência de treinamento especializado dos funcionários para a produção flores e plantas ornamentais. Como pode ser verificado na Tabela $23,58,1 \%$ e $75,0 \%$ dos produtores que distribuem via SC e SPR respectivamente, investem em treinamento dos funcionários. Esse treinamento é realizado através de cursos promovidos pela Cooperativa Veiling ou empresas especializadas.

Os produtores que distribuem via SPT1 e SPT2 investem menos em treinamento de funcionários ( $41,3 \%$ e $14,3 \%$ respectivamente). Esse treinamento é realizado pelo próprio produtor. A maioria dos produtores que distribui via SPT1, treinam seus funcionários de acordo com a espécie produzida e a maioria dos produtores que distribui via SPT2 por função/operação, ou seja, o funcionário só realiza determinada fase do processo de produção como plantio, irrigação, etc.

A última forma utilizada para medir a especificidade de ativo humano foi através do grau de substitubilidade dos funcionários, ou seja, se esses são específicos para a atividade.

Pela análise da Tabela 25 , observa-se que a maioria dos produtores considera dificil a substituição de seus funcionários $(65,2 \%, 61,9 \%, 51,6 \%$ e $75,0 \%$ dos produtores que distribuem via SPT1, SPT2, SC e SPR respectivamente).

Através dos resultados apresentados nas Tabelas 22 e 23 , classifica-se a especificidade de ativos humano como alta para os produtores que distribuem via $\mathrm{SC}$ e SPR, quando comparado aos produtores que distribuem via SPT1 e SPT2, devido ao maior investimento em capital humano empregado na produção e em treinamento especializado para seus funcionários. Como não houve contraste das freqüências nas 
variáveis relacionadas ao grau de substitubilidade dos funcionários, essas variáveis não serviram para explicar o grau de especificidade de ativos humano.

A Tabela 26 mostra resumidamente a classificação (alta e baixa) dos principais tipos de especificidades relacionadas ao ativo flor nas transações entre produtores e os sistemas de distribuição atacadista analisados nesse trabalho.

Tabela 26. Classificação dos principais tipos de especificidades relacionadas ao ativo flor nas transações entre produtores e os sistemas de distribuição.

\begin{tabular}{lllll}
\hline $\begin{array}{l}\text { Especificidade } \\
\text { dos Ativos }\end{array}$ & SPT1 & SPT2 & SC & SPR \\
\hline Físicos & baixa & baixa & alta & alta \\
Marca & baixa & baixa & alta & alta \\
Humana & baixa & baixa & alta & alta \\
\hline
\end{tabular}

\subsubsection{Frequiência da Transação}

A importância da frequêencia da transação reside na sua relação com a escala de produção (pois quanto maior a frequêencia, maior a possibilidade de internalizar a transação com ganhos de escala) e com a possibilidade de conhecer melhor o agente com quem se estabelece a transação. Ela foi medida analisando a periodicidade semanal em que ocorrem as transações entre produtores e os sistemas de distribuição.

Para os produtores que distribuem na Praça da Batata, Cebola e Flores (PBCF) e no pavilhão do Mercado Livre do Produtor (MLP) do SPT1, as transações podem ocorrer até quatro vezes por semana. Para os produtores que distribuem no SPT2, as transações podem ocorrer até seis vezes por semana; no entanto, a maioria transaciona duas vezes por semana. As transações entre produtores e o SC podem ocorrer até cinco vezes por semana e para os produtores que distribuem via SPR, até seis vezes por semana (Tabela 42 - APÊNDICE 1). 
Todas as transações realizadas para a venda de flores e plantas ornamentais são classificadas como recorrentes, pois existe uma necessidade continuada por parte de produtores e compradores e a perecibilidade do produto não permite grande tempo de estocagem.

\subsubsection{Incerteza}

A incerteza foi analisada como aquela inerente à própria atividade e a proveniente do comportamento estratégico dos agentes.

A incerteza inerente à própria atividade relaciona-se aos problemas de pragas e doenças, clima e manejo da cultura.

Pragas e doenças na produção de flores e plantas ornamentais ocasionam grandes prejuízos na qualidade final do produto. Estas provocam injúrias nas flores, conferindolhes má aparência e maior perecibilidade. Assim, a produção de flores e plantas ornamentais exige um monitoramento seqüencial e aplicação de produtos químicos constantemente. Os produtores que detêm tecnologia de aplicação possuem maior eficiência no controle de pragas e doenças, garantindo melhor qualidade da produção.

As Tabelas 27 e 28 demonstram o modo e a freqüência de controle de pragas e doenças para os produtores que distribuem para os quatro sistemas de distribuição analisados neste trabalho.

Tabela 27. Modo de controle de pragas e doenças pelos produtores.

\begin{tabular}{lcccccccc}
\hline & \multicolumn{2}{c}{ SPT1 } & \multicolumn{2}{c}{ SPT2 } & \multicolumn{2}{c}{ SC } & \multicolumn{2}{c}{ SPR } \\
Alternativa & $f$ & $\%$ & $f$ & $\%$ & $f$ & $\%$ & $f$ & $\%$ \\
\hline $\begin{array}{l}\text { Seqüencial } \\
\text { Conforme a }\end{array}$ & 38 & 82,6 & 34 & 81,0 & 20 & 64,5 & 4 & 100,0 \\
necessidade & 8 & 17,4 & 8 & 19,0 & 11 & 35,5 & 0 & 0,0 \\
\hline Total & 46 & 100,0 & 42 & 100,0 & 31 & 100,0 & 4 & 100,0 \\
\hline
\end{tabular}

Fonte: Dados da pesquisa 
Tabela 28. Freqüência para os produtores que realizam o controle seqüencial.

\begin{tabular}{lcccccccc}
\hline & \multicolumn{2}{c}{ SPT1 } & \multicolumn{2}{c}{ SPT2 } & \multicolumn{2}{c}{ SC } & \multicolumn{2}{c}{ SPR } \\
Alternativa & $f$ & $\%$ & $f$ & $\%$ & $f$ & $\%$ & $f$ & $\%$ \\
\hline 1xsemana & 21 & 55,3 & 16 & 47,0 & 11 & 55,0 & 0 & 0,0 \\
2xsemana & 11 & 28,9 & 11 & 32,4 & 5 & 25,0 & 0 & 0,0 \\
3xsemana & 0 & 0,0 & 2 & 5,9 & 0 & 0,0 & 0 & 0,0 \\
Quinzenalmente & 4 & 10,6 & 4 & 11,8 & 0 & 0,0 & 0 & 0,0 \\
Diariamente & 1 & 2,6 & 1 & 2,9 & 2 & 10,0 & 3 & 75,0 \\
Não respondeu & 1 & 2,6 & 0 & 0,0 & 2 & 10,0 & 1 & 25,0 \\
\hline \hline Total & 38 & 100,0 & 34 & 100,0 & 20 & 100,0 & 4 & 100,0 \\
\hline
\end{tabular}

Fonte: Dados da pesquisa

Observa-se um menor nível de incerteza para todos os produtores quando analisados os problemas com pragas e doenças, pois o principal modo de controle é o seqüencial. Para a maioria dos produtores que distribui via SPT1, SPT2 e SC o controle seqüencial ocorre de uma a duas vezes por semana e para a maioria dos produtores que distribui via SPR, o controle ocorre diariamente (Tabela 28).

O clima é um dos fatores que mais afeta a produção das flores. O cultivo pode ser feito a céu aberto, sob coberturas ou em estufas. O cultivo feito a céu aberto é totalmente suscetivel às intempéries climáticas como elevadas precipitações, geadas, ventos fortes, chuvas de granizo, etc. Devido ao menor custo de construção, grande parte das propriedades fazem o cultivo protegido utilizando estruturas de madeira cobertas com plásticos, que auxiliam a evitar o prejuizo provocado por intempéries climáticas, mas são pouco eficientes no controle climático (estufas simples). Os produtores mais capitalizados possuem estufas de estrutura metálica e climatizada. Estas estufas podem possuir mecanismos de controle de temperatura, através de sistemas que permitem aquecimento e/ou resfriamento, de umidade relativa (auxilia no controle de pragas e doenças), de fotoperíodo (regula a época de floração), de intensidade luminosa e concentração de $\mathrm{CO}_{2}$ (alteram a eficiência fotossintética).

Como analisado anteriormente, os produtores geralmente utilizam sistema coberto de produção. Entretanto, a maioria dos produtores entrevistados que distribui via $\mathrm{SC}$ e 
SPR utiliza estufas climatizadas ou semi-climatizadas e a maioria que distribui via SPT1 e SPT2 utiliza estufas simples (Tabelas 17 e 18).

Outro fator que contribui para diminuir a incerteza inerente à própria atividade é o manejo adequado da cultura, através da adubação, uso de hormônios, entre outros, que permite uma maior uniformidade da produção e durabilidade do produto final. Uma adubação correta (época e forma de aplicação, fonte e quantidade de nutrientes, etc) promove um desenvolvimento adequado e maior sanidade da cultura, pois plantas com boa nutrição são menos suscetiveis ao ataque de pragas e doenças. Através da utilização de hormônios vegetais pode-se conseguir floração em uma mesma época, garantindo uma padronização da produção.

O emprego de tecnologia para a produção de flores acarreta efeitos positivos na qualidade final do produto (aparência, perecibilidade, padronização, etc.). Assim, os produtores que utilizam maiores recursos tecnológicos apresentam produtos finais com qualidade superior aos que adotam menor nível de tecnologia.

Os produtores que distribuem sua produção via SPT1 e SPT2 apresentaram maior incerteza inerente à própria atividade, por utilizar um menor nível tecnológico. Já aqueles produtores que comercializam via SC e SPR, a incerteza inerente à própria atividade é menor, pois empregam um maior nível tecnológico, como o manejo adequado e uso de estufas com ambiente controlado.

Como pode ser verificado na Tabela 29 , segundo os produtores que distribuem via SPT 1 o maior risco associado à sua produção é o clima (41,3\% dos entrevistados) e para os produtores que distribuem via SPT2 (45,2\% dos entrevistados) existem muitos fatores de risco (como o clima, uniformidade na produção, entre outros). Para os produtores que distribuem via SC e SPR não existe um grande risco associado à sua produção (29,0\% e 75\% dos entrevistados respectivamente). 
Tabela 29. Maior risco associado à produção segundo os produtores.

\begin{tabular}{lcccccccc}
\hline & \multicolumn{2}{c}{ SPT1 } & \multicolumn{2}{c}{ SPT2 } & \multicolumn{2}{c}{ SC } & \multicolumn{2}{c}{ SPR } \\
Alternativa & $f$ & $\%$ & $f$ & $\%$ & $f$ & $\%$ & $f$ & $\%$ \\
\hline Padronização & 8 & 17,4 & 6 & 14,3 & 7 & 22,6 & 0 & 0,0 \\
Clima & 19 & 41,3 & 6 & 14,3 & 8 & 25,8 & 1 & 25,0 \\
Pragas e doenças & 7 & 15,2 & 8 & 19,0 & 6 & 19,4 & 0 & 0,0 \\
Aquisição de insumos & 0 & 0,0 & 2 & 4,8 & 0 & 0,0 & 0 & 0,0 \\
Todos & 12 & 26,1 & 19 & 45,2 & 1 & 3,2 & 0 & 0,0 \\
Nenhum & 0 & 0,0 & 1 & 2,4 & 9 & 29,0 & 3 & 75,0 \\
\hline Total & 46 & 100,0 & 42 & 100,0 & 31 & 100,0 & 4 & 100,0 \\
\hline
\end{tabular}

Fonte: Dados da pesquisa

Com relação à incerteza proveniente do comportamento estratégico dos agentes, os produtores de flores e plantas ornamentais sofrem com a inadimplência. Existe a assimetria de informações entre os agentes envolvidos na transação, que não os permitem prever a atuação um do outro.

Os produtores que distribuem pelo SC são os únicos que não sofrem com esse tipo de incerteza, pois existe o controle eletrônico do crédito dado aos compradores. Já os produtores que distribuem via SPT1, SPT2 e SPR não recebem nenhuma garantia contra a inadimplência desses sistemas.

A Tabela 30 analisa o maior risco associado à venda segundo os produtores. A inadimplência é considerada o maior risco para $63,0 \%$ dos produtores que distribuem via SPT1 e $71,4 \%$ dos produtores que distribuem via SPT2. Para os produtores que distribuem via SC e SPR o maior risco associado à venda é a demanda instável por flores e plantas ornamentais, que ainda é concentrada nas datas de pico, como dia das mães, Finados, Natal, etc $(38,7 \%$ e $50 \%$ dos entrevistados respectivamente). É importante ressaltar que existe uma incidência relevante de produtores que distribuem via SPR, que não indicaram problemas em relação as vendas ( $50 \%$ dos entrevistados). 
Tabela 30. Maior risco associado à venda segundo os produtores.

\begin{tabular}{lcccccccc}
\hline & \multicolumn{2}{c}{ SPT1 } & \multicolumn{2}{c}{ SPT2 } & \multicolumn{2}{c}{ SC } & \multicolumn{2}{c}{ SPR } \\
Alternativa & $f$ & $\%$ & $f$ & $\%$ & $f$ & $\%$ & $f$ & $\%$ \\
\hline Inadimplência & 29 & 63,0 & 30 & 71,4 & 0 & 0,0 & 0 & 0,0 \\
Demanda instável & 5 & 10,9 & 1 & 2,4 & 12 & 38,7 & 2 & 50,0 \\
Preço & 4 & 8,7 & 5 & 11,9 & 11 & 35,5 & 0 & 0,0 \\
Todos & 6 & 13,1 & 4 & 9,5 & 0 & 0,0 & 0 & 0,0 \\
Nenhum & 2 & 4,3 & 2 & 4,8 & 8 & 25,8 & 2 & 50,0 \\
\hline \hline Total & 46 & 100,0 & 42 & 100,0 & 31 & 100,0 & 4 & 100,0 \\
\hline
\end{tabular}

Fonte: Dados da pesquisa

\subsection{Estruturas de governança esperadas nas transações entre produtores e sistemas de distribuição de flores e plantas ornamentais}

A estrutura de governança esperada (via mercado, híbrida ou hierárquica), em termos de redução de custos de transação, variou em função da especificidade dos ativos (ver Figura 8).

A estrutura de governança via mercado foi a resultante nas transações existentes entre produtores e o SPT1 e SPT2, uma vez que a especificidade de ativos fisicos, marca e humana foram baixas.

A não especificidade de ativos físicos decorreu do baixo investimento em componentes específicos utilizados para a produção de flores e plantas ornamentais e da inexistência de estruturas específicas nos sistemas de distribuição que contribuiram para manutenção da qualidade e durabilidade dos produtos. Os ativos marca também foram não-especificos devido ao baixo investimento de capital na marca do produto. Já a baixa especificidade de ativos humano decorreu do menor investimento tanto em capital humano empregado para a produção, quanto no treinamento especializado para os funcionários.

Nesse tipo de estrutura existe um grande número de compradores e vendedores de cada lado da transação e o sistema de preços é suficiente para assegurar o ajuste do mercado. 
Nas transações existentes entre produtores e o SC e SPR, a estrutura de governança resultante foi a híbrida, já que a especificidade de ativos fisicos, marca e humana aumentaram. Esses sistemas de distribuição unem oferta e demanda, atuando como uma mão visivel (portanto não mercado na forma estrita) no processo de troca de direito de propriedade.

A alta especificidade dos ativos físicos decorreu dos elevados investimentos em componentes específicos para a produção de flores e plantas ornamentais. Além disso, esses sistemas de distribuição investiram em estruturas específicas que contribuíram para manutenção da qualidade e durabilidade dos produtos.

Os ativos marca também possuíram especificidade alta devido ao elevado investimento de capital na marca do produto e a alta especificidade de ativos humano decorreu do elevado investimento em capital humano empregado na produção e no treinamento especializado dos funcionários.

\subsection{Aspectos de eficiência e ineficiência dos sistemas de distribuição de flores e plantas ornamentais}

Através dos indicadores-chave sinalizou-se em quais aspectos um determinado sistema de distribuição foi mais eficiente que os demais. Os resultados obtidos no questionário, que foram utilizados para os cálculos dos indicadores-chave, podem ser analisados no APÊNDICE 1.

O primeiro indicador-chave sinalizou o faturamento do sistema de distribuição por tempo de comercialização, como mostra a Tabela 31. 
Tabela 31. Faturamento do sistema de distribuição ${ }^{1} /$ tempo de comercialização ${ }^{2}$.

\begin{tabular}{lc}
\hline Sistema de distribuição & R\$/hora \\
\hline SPT1 & $91.907,00$ \\
SPT2 & $85.272,00$ \\
SC & $25.341,00$ \\
SPR & $4.204,00$ \\
\hline
\end{tabular}

Fonte: Dados da pesquisa

1 Cálculo realizado com o faturamento acumulado dos sistemas de distribuição de janeiro a outubro de 1999.

2 Cálculo realizado com o tempo total gasto com a comercialização de flores e plantas omamentais de janeiro a outubro de 1999.

A análise dos resultados demonstra que o SPT1 é o mais eficiente no aspecto faturamento por hora de comercialização. Quando analisado o faturamento, acumulado de janeiro a outubro de 1999, o SPT1 faturou aproximadamente três vezes mais que o SPT2, duas vezes mais que o $\mathrm{SC}$ e onze vezes mais que o SPR (ver Tabela 41 APÊNDICE 1). O principal motivo para esse elevado faturamento é a demanda por flores e plantas ornamentais existente no SPT1. Essa demanda decorre da localização do sistema na cidade de São Paulo, o maior mercado consumidor brasileiro, da grande quantidade de variedades de flores e plantas ornamentais oferecidas (como pode ser analisada pelas respostas dos consumidores apresentadas na Tabela 59 - APÊNDICE 1) e da facilidade de entrada de quaisquer compradores no SPT1, pois não é exigido um cadastro dos consumidores.

O SPT2 também apresenta um elevado faturamento por hora de comercialização. O principal motivo para isso é o menor tempo gasto para realizar a comercialização quando comparado aos demais sistemas. (Tabelas 43 e 44 - APÊNDICE 1).

Já o SC, apesar de registrar o segundo maior faturamento entre os sistemas, apresenta elevado tempo médio de comercialização (Tabelas 41, 43 e 44 - APÊNDICE 1), tornando-o menos eficiente que o SPT1 e o SPT2 no indicador-chave analisado.

O SPR apresenta o menor faturamento por hora de comercialização quando comparada aos demais sistemas. Esse sistema gasta mais tempo para a comercialização e apresenta o menor faturamento. $\mathrm{O}$ menor faturamento pode ser decorrente da quantidade 
ainda restrita de produtos e variedades oferecida pelo sistema de distribuição (como pode ser analisada pelas respostas dos consumidores apresentadas na Tabela 66 - APÊNDICE $1)$.

O segundo indicador-chave determinou o faturamento do sistema de distribuição por hora-homem trabalhada. Os resultados estão representados na Tabela 32.

Tabela 32. Faturamento do sistema de distribuição ${ }^{1 /}$ hora-homem trabalhada ${ }^{2}$.

\begin{tabular}{lc}
\hline Sistema de distribuição & R\$/hora-homem trabalhada \\
\hline SPT1 & 68,53 \\
SPT2 & 112,94 \\
SC & 193,93 \\
SPR & 262,76 \\
\hline
\end{tabular}

Fonte: Dados da pesquisa

1 Cálculo realizado com o faturamento acumulado dos sistemas de distribuição de janeiro a outubro de 1999.

${ }^{2}$ Cálculo realizado com o tempo total de trabalho de todos os funcionários de janeiro a outubro de 1999 .

A leitura da Tabela 32 permite analisar alguns aspectos interessantes. O SPT1 é o que apresenta o maior faturamento, entretanto, a cada hora-homem trabalhada é o sistema de distribuição que menos fatura, mostrando a baixa produtividade dos produtores e funcionários que ali comercializam.

Analisando o mesmo indicador-chave, nota-se que o SPR apresenta o maior faturamento por hora-homem trabalhada, utilizando-se menos funcionários (Tabela 45 APÊNDICE 1), mostrando a elevada produtividade dos funcionários quando comparado ao SPT1, SPT2 e SC.

O terceiro indicador-chave mediu o tempo de ociosidade por homem no período de um dia, como pode ser verificado na Tabela 33 a seguir: 
Tabela 33. Tempo de ociosidade/homem no periodo de um dia.

\begin{tabular}{lc}
\hline \multicolumn{1}{c}{ Sistema de distribuição } & horas/homem \\
\hline SPT1 & $3 \mathrm{hrs} 45 \mathrm{~min}$ \\
SPT2 & $2 \mathrm{hrs} 44 \mathrm{~min}$ \\
SC & n.d. \\
SPR & Ohrs \\
\hline
\end{tabular}

Fonte: Dados da pesquisa

n.d.: dados não disponíveis para este sistema de distribuição.

Entre os sistemas de distribuição dos quais foram possiveis obter informações sobre o tempo de ociosidade do funcionário, o SPT1 é o mais ineficiente, seguido do SPT2. Nesses sistemas, é comum observar funcionários ociosos, esperando o consumidor para realizar a comercialização. Já no SPR, os funcionários encontram-se trabalhando em tempo integral na comercialização.

O quarto indicador-chave mostrou o faturamento do sistema de distribuição por área total utilizada para a comercialização (Tabela 34).

Tabela 34. Faturamento do sistema de distribuição 1/área total utilizada para a comercialização.

\begin{tabular}{lc}
\hline Sistema de distribuição & $\mathrm{R} \$ / \mathrm{m}^{2}$ \\
\hline SPT1 & $2.232,00$ \\
SPT2 & $2.470,00$ \\
SC & $1.962,00$ \\
SPR & $7.927,00$ \\
\hline
\end{tabular}

Fonte: Dados da pesquisa

${ }^{1}$ Cálculo realizado com o faturamento acumulado dos sistemas de distribuição de janeiro a outubro de 1999.

O sistema de distribuição mais eficiente em termos de faturamento por área total utilizada para a comercialização é o SPR. Apesar de um baixo faturamento, quando comparado aos demais sistemas, o SPR utiliza uma pequena área para a comercialização (Tabela 8 e Tabela 41 - APÊNDICE 1). 
O SPR trabalha com gestão comercial e administrativa e orientação logística. $O$ produtor somente transporta o produto para o sistema quando o mesmo já está vendido. Ao chegar no sistema o produto é carregado pelo comprador ou em alguns casos, fica estocado por um periodo curto de tempo em uma câmara fria. Por esses motivos, não é necessário uma área de grande proporção para armazenamento.

Os demais sistemas de distribuição apresentam o indicador-chave faturamento por área total utilizada para a comercialização muito semelhante. Todos os produtos que serão comercializados permanecem nos sistemas até serem vendidos, demandando mais área de armazenamento.

O quinto indicador-chave que foi utilizado para sinalizar aspectos de eficiência e ineficiência de um sistema de distribuição, referiu-se à contribuição do mesmo na manutenção da qualidade do produto. Para Slack, citado por Riguetti \& Fusco (1999), qualidade significa "fazer certo as coisas", em resumo, produzir de acordo com as especificações do cliente, processo e normas. O objetivo qualidade proporciona menor custo e maior confiabilidade.

$O$ indicador-chave contribuição do sistema de distribuição na manutenção da qualidade do produto foi medido pela quantidade de vezes em que o produto é manuseado e pela existência de estruturas específicas que contribuíram com a qualidade do produto nos sistemas analisados.

A Tabela 35 mostra a quantidade de vezes em que o produto é manuseado nos sistemas de distribuição desde o descarregamento até o carregamento pelo consumidor.

Tabela 35. Quantidade de vezes em que se manuseia o produto.

\begin{tabular}{lcccc}
\hline & \multicolumn{2}{c}{ SPT1 } & \multicolumn{2}{c}{ SPT2 } \\
Alternativa & $f$ & $\%$ & $f$ & $\%$ \\
\hline Nenhuma vez & 0 & 0,0 & 0 & 0,0 \\
1 vez & 0 & 0,0 & 0 & 0,0 \\
2 vezes & 6 & 13,0 & 5 & 11,9 \\
3 vezes & 19 & 41,3 & 28 & 66,7 \\
Mais de 3 vezes & 21 & 45,7 & 9 & 21,4 \\
\hline \hline Total & 46 & 100 & 42 & 100 \\
\hline
\end{tabular}

Fonte: Dados da pesquisa 
No SC e SPR não existe contato fisico com o produto, pois toda movimentação, desde o descarregamento até o carregamento pelo consumidor, é realizada em carrinhos apropriados que já chegam carregados da produção.

O manuseio das flores e plantas ornamentais acarreta perda de qualidade. Os produtos dessa categoria já têm sua durabilidade prejudicada pelas suas características de perecibilidade e sujeição às variações climáticas. Isto se agrava com o grande número de manuseio nessa fase de comercialização.

A Tabela 35 mostra que $45,7 \%$ dos produtores que distribuem via SPT1 manuseiam o produto mais de 3 vezes e $66,7 \%$ dos produtores que distribuem via SPT2 manuseiam o produto 3 vezes. Esse manuseio excessivo por parte dos produtores ocasiona perda de qualidade aos produtos. O SC e o SPR são sistemas que contribuem com a qualidade do produto oferecido, pois não existe o manuseio do mesmo.

Em relação à existência de estruturas que contribuam com a qualidade do produto, como já foi mencionado anteriormente, o SC investe em câmaras frias, pátio climatizado e plataforma para o carregamento e descarregamento dos produtos e o SPR também investe em câmaras frias, plataforma para o carregamento e descarregamento dos produtos e em laboratório de análise de pós-colheita.

No SPT1 e no SPT2 inexistem estruturas especificas para manutenção da qualidade do produto.

Conclui-se portanto que o SPT1 e o SPT2 são ineficientes quanto ao indicadorchave contribuição do sistema de distribuição na manutenção da qualidade do produto quando comparado aos demais sistemas, devido ao elevado manuseio e a inexistência de estruturas especificas para manter qualidade do produto.

O sexto indicador-chave utilizado, refere-se ao grau de satisfação do consumidor. De acordo com Plossl, citado por Riguetti \& Fusco (1999), para que uma empresa mantenha-se competitiva no mercado é necessário desenvolver indicadores externos que possibilitam a comparação entre o produto fornecido com a expectativa do cliente. A expectativa do cliente abrange vários aspectos, não somente ao desempenho do produto em si, mas também como a empresa disponibiliza o produto em função aos 
prazos de entrega e a assistência dada ao cliente. A função da empresa é resolver o problema do seu cliente, ou seja, atender suas necessidades.

$\mathrm{O}$ indicador-chave foi medido pela satisfação do consumidor em relação à qualidade do produto oferecido, coerência entre o preço e qualidade e outros problemas apresentados nos sistemas de distribuição.

A Figura 10 mostra a satisfação do consumidor em relação à qualidade do produto oferecido. As Tabelas 36 e 37 avaliam se o preço pago pelo produto é coerente com a sua qualidade e motivos da incoerência. Outros problemas apresentados nos sistemas de distribuição de acordo com os consumidores podem ser analisados nas Tabelas 63, 64, 65 e 66 - APÊNDICE 1.

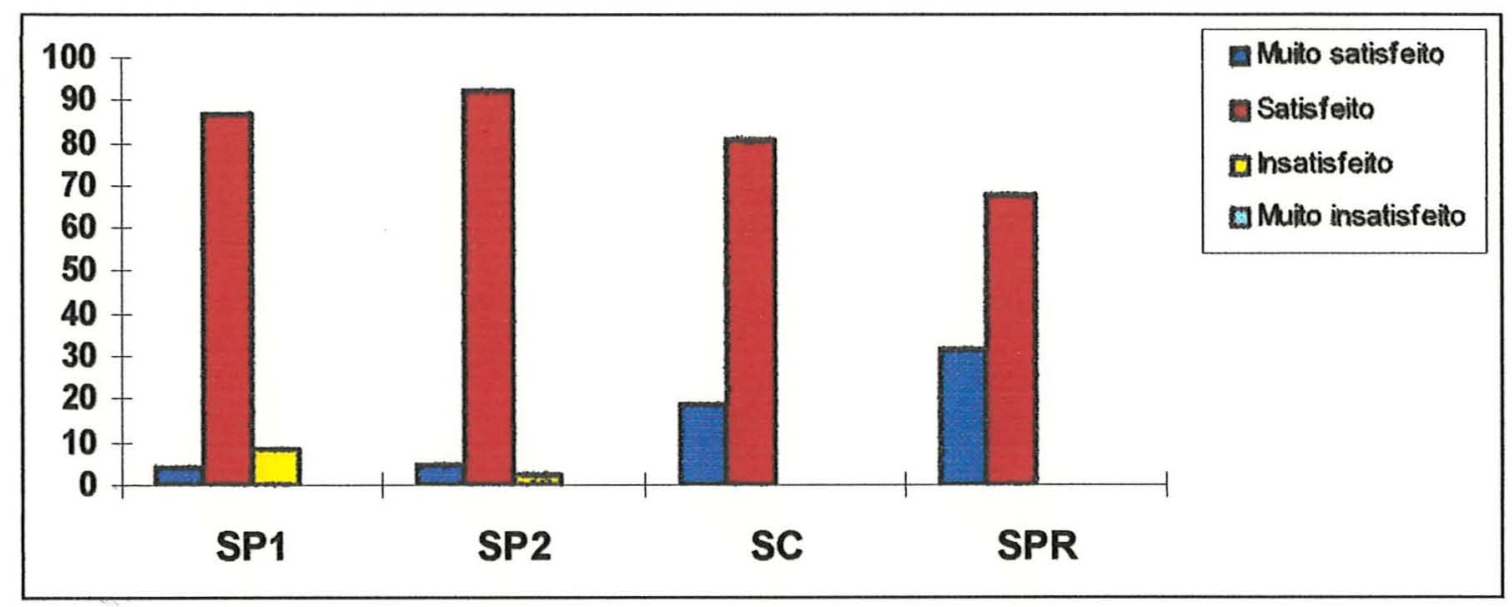

Figura 10 - Satisfação do consumidor em relação à qualidade do produto (valores em porcentagem de entrevistados).

Fonte: Dados da pesquisa.

A análise da Figura 10 demonstra que a maioria dos consumidores está satisfeita em relação à qualidade do produto oferecido pelos sistemas de distribuição. É importante ressaltar que há uma incidência de $8,7 \%$ de consumidores do SPT1 insatisfeitos. 
Tabela 36. Preço pago pelo produto é coerente com a sua qualidade.

\begin{tabular}{lcccccccc}
\hline & \multicolumn{2}{c}{ SPT1 } & \multicolumn{2}{c}{ SPT2 } & \multicolumn{2}{c}{ SC } & \multicolumn{2}{c}{ SPR } \\
Alternativa & $f$ & $\%$ & $f$ & $\%$ & $f$ & $\%$ & $f$ & $\%$ \\
\hline Sim & 25 & 54,3 & 32 & 78,0 & 30 & 81,1 & 16 & 84,2 \\
Não & 21 & 45,7 & 9 & 22,0 & 7 & 18,9 & 3 & 15,8 \\
\hline Total & 46 & 100,0 & 41 & 100,0 & 37 & 100,0 & 19 & 100,0 \\
\hline
\end{tabular}

Fonte: Dados da pesquisa

Tabela 37. O motivo da incoerência entre preço e qualidade.

\begin{tabular}{lcccccccc}
\hline & \multicolumn{2}{c}{ SPT1 } & \multicolumn{2}{c}{ SPT2 } & \multicolumn{2}{c}{ SC } & \multicolumn{2}{c}{ SPR } \\
Alternativa & $f$ & $\%$ & $f$ & $\%$ & $f$ & $\%$ & $f$ & $\%$ \\
\hline Falta qualidade no produto & 11 & 52,4 & 5 & 55,6 & 6 & 85,7 & 1 & 33,3 \\
Pouca durabilidade & 2 & 9,5 & 0 & 0,0 & 0 & 0,0 & 0 & 0,0 \\
Preço alto & 2 & 9,5 & 2 & 22,2 & 1 & 14,3 & 1 & 33,3 \\
Falta de padronização & 5 & 23,8 & 2 & 22,2 & 0 & 0,0 & 0 & 0,0 \\
Outros & 1 & 4,8 & 0 & 0,0 & 0 & 0,0 & 1 & 33,3 \\
\hline \hline Total & 21 & 100,0 & 9 & 100,0 & 7 & 100,0 & 3 & 100,0 \\
\hline
\end{tabular}

Fonte: Dados da pesquisa

No entanto, quando o consumidor foi questionado sobre a coerência entre o preço e a qualidade dos produtos oferecidos pelos sistemas, a leitura das Tabelas 36 e 37 permite observar alguns aspectos interessantes.

Dos consumidores do SPT1, 45,7\% dos entrevistados não acham o preço pago pelo produto coerente com a sua qualidade. Os principais motivos são a baixa qualidade e a falta de padronização dos produtos oferecidos. Em relação aos demais sistemas, essas porcentagens são menores. No SPT2, SC e SPR, dos consumidores entrevistados, $22 \%$, $18,9 \%$ e $15,8 \%$ respectivamente, não acham o preço pago pelo produto coerente com a sua qualidade. Para esses sistemas, um dos principais motivos dessa falta de coerência é a baixa qualidade dos produtos oferecidos.

Outros problemas apresentados no SPT1 são a freqüência conjunta de consumidores, como varejistas, atacadistas e consumidor final, que pagam o mesmo preço pelos produtos e a falta de um estacionamento organizado e com mais espaço. No 
SPT2 os consumidores não estão satisfeitos com o horário de abertura, pois o início do expediente poderia ser antecipado. Em contrapartida, em relação ao SC e SPR, a maioria dos consumidores não apresentou nenhum problema (ver Tabelas 63, 64, 65 e 66 APÊNDICE 1).

Através da análise do indicador-chave grau de satisfação do consumidor, verificase que, em geral, todos os sistemas são eficientes com relação a esse aspecto. É observada uma menor eficiência relacionada à coerência entre qualidade e preço dos produtos, freqüência conjunta de consumidores e a falta de um estacionamento organizado e com mais espaço no SPT1 e ao horário de abertura do SPT2.

É interessante ressaltar que os principais motivos da utilização do SPT1 e SPT2 pelos consumidores são a localização privilegiada e as variedades de produtos oferecidas pelos sistemas. Já no SC é o preço e a garantia da qualidade dos produtos e no SPR a garantia da qualidade dos produtos (ver Tabelas 59, 60, 61 e 62 - APÊNDICE 1).

$\mathrm{O}$ último indicador-chave utilizado neste trabalho mediu o tempo de carregamento gasto pelo consumidor, ou seja, o quanto o sistema de distribuição consegue ser ágil na entrega dos produtos, após a compra pelo consumidor. De acordo com Plossl, citado por Riguetti \& Fusco (1999), reduzir os tempos de entrega sem aumentar os estoques é um bom indicador da eficácia, que implicará em uma redução de custos operacionais e tạmbém irá melhorar a imagem da empresa no mercado, sendo também um componente forte de competitividade. A Tabela 38 mostra o tempo gasto com o carregamento pelo consumidor.

A análise dos resultados demonstra que o SPR é o mais eficiente no aspecto tempo gasto com o carregamento pelo consumidor, quando comparado aos demais sistemas. O pedido do produto pelo consumidor do SPR é realizado com um dia de antecedência, podendo a partir dai já ser retirado. Como existe uma plataforma para o carregamento e descarregamento dos produtos, o consumidor perde pouco tempo com essa fase da comercialização. 
Tabela 38. Tempo gasto com o carregamento pelo consumidor.

\begin{tabular}{lcccccccc}
\hline & \multicolumn{2}{c}{ SPT1 } & \multicolumn{2}{c}{ SPT2 } & \multicolumn{2}{c}{ SC } & \multicolumn{2}{c}{ SPR } \\
Alternativa & $f$ & $\%$ & $f$ & $\%$ & $f$ & $\%$ & $f$ & $\%$ \\
\hline Nenhum & 0 & 0,0 & 0 & 0,0 & 0 & 0,0 & 0 & 0,0 \\
1 a 15 minutos & 0 & 0,0 & 2 & 4,9 & 1 & 2,7 & 8 & 42,1 \\
16 a 30 minutos & 3 & 7,0 & 1 & 2,4 & 2 & 5,4 & 8 & 42,1 \\
31 a 60 minutos & 14 & 32,5 & 10 & 24,4 & 10 & 27,0 & 1 & 5,3 \\
mais de 60 minutos & 26 & 60,5 & 28 & 68,3 & 24 & 64,9 & 2 & 10,5 \\
\hline \hline Total & 43 & 100,0 & 41 & 100,0 & 37 & 100,0 & 19 & 100,0 \\
\hline
\end{tabular}

Fonte: Dados da pesquisa

No SPT1 e no SPT2, logo que o produto é comprado, o consumidor demora a carregar o seu caminhão, já que não existe uma plataforma de carregamento e descarregamento. Além disso, na maioria das vezes, existe fila de espera de carros e caminhões na saída dos sistemas.

No $\mathrm{SC}$, depois que o produto é comprado, existe uma certa demora com a burocracia administrativa para a liberação do mesmo. Inicialmente é emitido um boleto de distribuição que identifica o produto. Com esse boleto os funcionários do SC separaram os lotes. Somente após essa separação, os lotes são encaminhados para a área de expedição.

\subsubsection{Vantagens e desvantagens dos sistemas de distribuição avaliadas pelos produtores}

Dependendo do aspecto analisado, um sistema de distribuição pode ser mais eficiente que os demais. Entretanto, os produtores possuem motivos para a escolha de um determinado sistema. A Tabela 39 resume os principais motivos da utilização dos sistemas de distribuição pelos produtores, ressaltando suas vantagens e desvantagens. 
Tabela 39. Resumo dos principais motivos, vantagens e desvantagens da utilização dos sistemas de distribuição pelos produtores.

\begin{tabular}{|c|c|c|c|}
\hline $\begin{array}{l}\text { Sistema de } \\
\text { Distribuição }^{1}\end{array}$ & Motivos da utilização & $\begin{array}{l}\text { Principais } \\
\text { Vantagens }\end{array}$ & $\begin{array}{l}\text { Principais } \\
\text { Desvantagens }\end{array}$ \\
\hline SPTI & $\begin{array}{l}\text { - Tradição } \\
\text { - Localização } \\
\text { privilegiada }\end{array}$ & $\begin{array}{l}\text { - Demanda pelos } \\
\text { produtos } \\
\text { - Recebimento à } \\
\text { vista }\end{array}$ & $\begin{array}{l}\text { - Horário de } \\
\text { funcionamento } \\
\text { - Falta de segurança }\end{array}$ \\
\hline SPT2 & $\begin{array}{l}\text { - Localização } \\
\text { privilegiada } \\
\text { - Demanda pelos } \\
\text { produtos }\end{array}$ & $\begin{array}{l}\text { - Localização } \\
\text { privilegiada } \\
\text { - Existência de um } \\
\text { cadastro de } \\
\text { consumidores }\end{array}$ & $\begin{array}{l}\text { - Excesso de taxas } \\
\text { cobradas } \\
\text { - Falta de } \\
\text { estacionamento }\end{array}$ \\
\hline SC & $\begin{array}{l}\text { - Segurança de } \\
\text { recebimento } \\
\text { - Rapidez nas vendas }\end{array}$ & $\begin{array}{l}\text { - Segurança de } \\
\text { recebimento } \\
\text { - Transparência na } \\
\text { formação do } \\
\text { preço }\end{array}$ & - Nenhuma \\
\hline SPR & $\begin{array}{l}\text { - Rapidez nas vendas } \\
\text { - Demanda pelos } \\
\text { produtos }\end{array}$ & $\begin{array}{l}\text { - Rapidez nas } \\
\text { vendas } \\
\text { - Sistema confiável }\end{array}$ & - Nenhuma \\
\hline
\end{tabular}

Fonte: Dados da pesquisa

${ }^{1}$ Os resultados detalhados podem ser analisados nas Tabelas $47,48,49,50,51,52,53,54,55$, 56,57 e 58 - APÊNDICE 1). 


\section{CONCLUSÕES}

Este trabalho analisou as transações existentes entre produtores e sistemas de distribuição atacadista de flores e plantas ornamentais do Estado de São Paulo. Foram avaliadas quatro categorias distintas de sistemas de distribuição: um público tradicional (SPT1), um público tradicional com um mercado permanente de flores e plantas ornamentais (SPT2), um cooperativo (SC) e um privado (SPR), representados respectivamente pela CEAGESP, CEASA Campinas, Veiling Holambra e a empresa FLORANET.

Utilizou-se como referencial teórico, para identificar as variáveis relevantes na determinação das estruturas de governança existentes, a Economia dos Custos de Transação.

A estrutura de governança via mercado foi a resultante nas transações existentes entre produtores e o SPT1 e o SPT2, decorrente da baixa especificidade dos ativos físicos, marca e humana. A estrutura de governança híbrida foi a resultante nas transações existentes entre produtores e o SC e o SPR, visto que nesses casos as especificidades aumentaram.

Também foram sinalizados aspectos de eficiência e ineficiência dos sistemas de distribuição atacadista, através de indicadores-chave.

Sabe-se que não existe uma fórmula mágica para mensuração da eficiência da empresa. Porém, a experiência mostra que o número dos indicadores relevantes é pequeno. Neste trabalho, por exemplo, foram utilizados sete indicadores-chave para 
contar como os sistemas de distribuição estão atuando e se eles estão se movendo na direção certa.

Os primeiros indicadores-chave deste trabalho (indicadores 1, 2, 3 e 4 - Tabela 40) mediram basicamente a produtividade dos sistemas de distribuição. Assim, foram relacionados alguns fatores de produção - tempo de comercialização, hora-homem trabalhada e área total utilizada para a comercialização - ao faturamento de cada sistema, bem como tempo de ociosidade por homem no período de comercialização, com as seguintes conclusões principais:

- O SPT1 e o SPT2 mostraram que é possivel obter um alto faturamento com menor tempo de comercialização; o SC e o SPR deverão avaliar o seu elevado tempo de comercialização quando comparados aos demais sistemas;

- o SC e o SPR registraram maior produtividade na relação faturamento por horahomem trabalhada; o SPT1 e o SPT2 possuem um elevado número de vendedores (produtores) e funcionários envolvidos na comercialização com elevada ociosidade e baixa produtividade;

- o SPR foi o mais eficiente em termos de faturamento por área total utilizada para comercialização, como resultado de seu modelo de comercialização eletrônico e de orientação logística.

O segundo conjunto de indicadores-chave deste trabalho (indicadores 5, 6 e 7 Tabela 40) mediram questões relacionadas à qualidade e satisfação do consumidor. Assim, foram analisadas as contribuições dos sistemas na manutenção da qualidade do produto, o grau de satisfação do consumidor e o tempo gasto com o carregamento pelo consumidor, com as seguintes conclusões principais:

- O SC e o SPR apresentaram maior contribuição na manutenção da qualidade dos produtos com métodos e práticas redutoras de danos mecânicos e estruturas 
específicas para manter a qualidade das flores e plantas como câmaras frias, pátio climatizado e laboratório de análise de pós-colheita. Os demais sistemas foram menos eficiente à essas questões por não investirem em estruturas especificas para o controle de qualidade;

- o SC e o SPR registraram um ótimo grau de satisfação do consumidor em relação à qualidade do produto, à coerência de preço e a outros fatores pesquisados; os demais sistemas também apresentaram um bom grau de satisfação do consumidor com algumas ressalvas registradas na Tabela 40;

- o SPR foi o mais eficiente em termos de tempo gasto com o carregamento pelo consumidor - mais um fator de satisfação do consumidor - como resultado de seu modelo de comercialização; o SPT1 e o SPT2 registraram elevado tempo de carregamento por não possuírem estruturas operacionais e logísticas adequadas e o SC não foi eficiente por motivos exclusivos de ordem burocrática.

O questionamento sobre qual seria o melhor indicador-chave é assunto de debate até mesmo entre os mais experientes administradores da área. Nenhuma das medidas é perfeita isoladamente, todas elas incorporam uma margem de erro e praticamente todas são adequadas.

É importante que se arquitete um sistema de indicadores tratados sob o enfoque sistêmico, buscando com isso medidas combinadas de eficiência. Assim é que produtividade e qualidade se combinam para gerar várias medidas de eficiência.

Em suma, o importante na sinalização de aspectos de eficiência e ineficiência apresentados neste trabalho, não foi a magnitude absoluta do indicador encontrada para o sistema de distribuição, mas sim a tendência - o que os matemáticos chamam de "inclinação da curva". Com essas informações, o gestor de cada sistema de distribuição atacadista poderá observar em quais aspectos esta sendo ineficiente e buscar melhorar seu desempenho. 


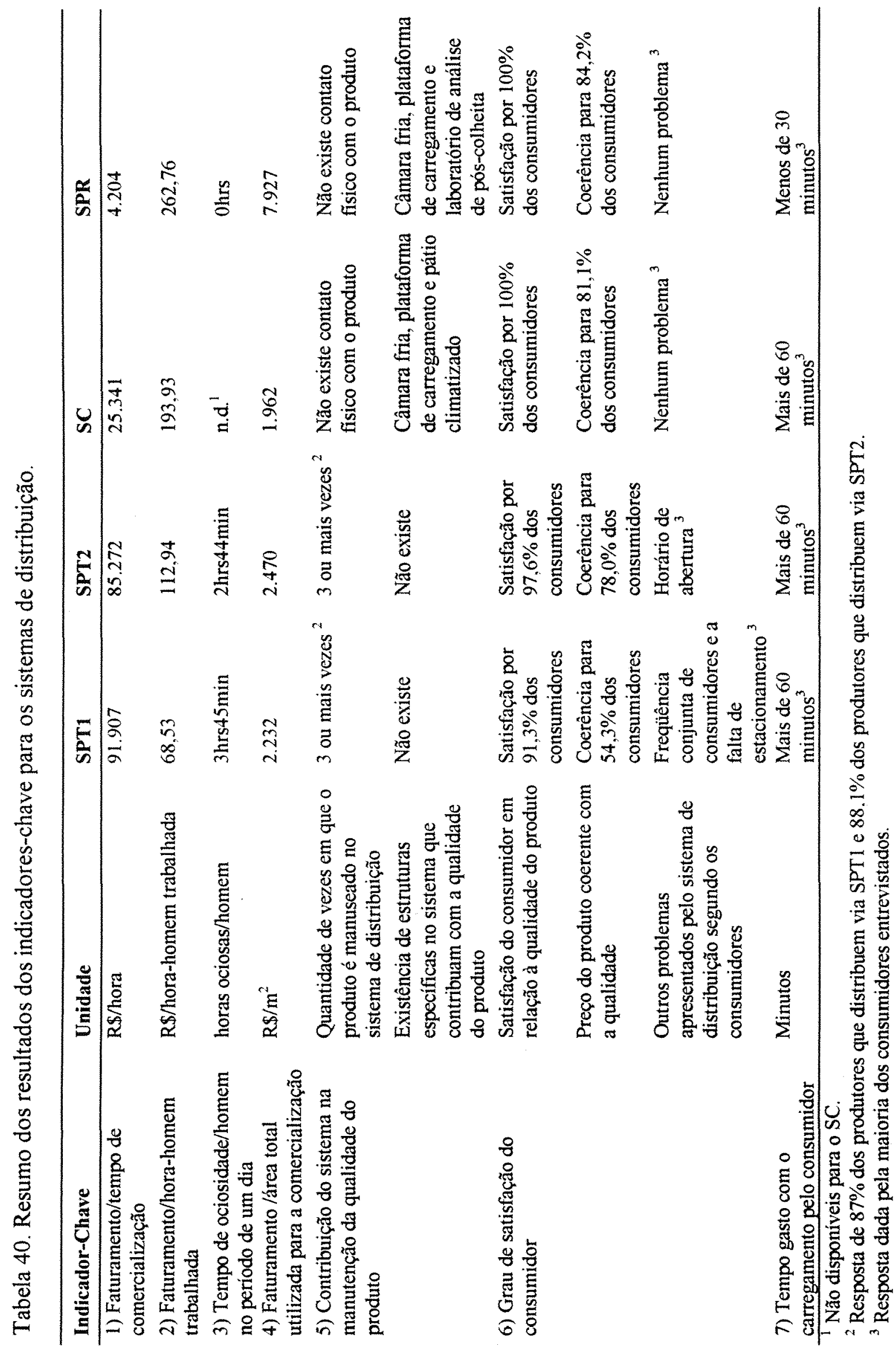




\section{Tendências para o Sistema Agroindustrial das Flores e Plantas Ornamentais}

Os próximos anos trarão mudanças mercadológicas profundas no setor de flores e plantas ornamentais e também nas estratégias e nos modelos gerenciais dos sistemas de distribuição atacadista, com as seguintes tendências principais que foram observadas durante a elaboração deste trabalho:

\section{- Mercado}

O Brasil não é um grande produtor de flores e plantas ornamentais, como os Estados Unidos, a Holanda e o Japão, mas há uma produção crescente, decorrente da organização e especialização dos produtores. O brasileiro, de modo geral, consome pouco o produto. Porém, o mercado brasileiro de flores e plantas ornamentais vem crescendo a um ritmo de cerca de $23 \%$ ao ano, com grandes perspectivas para o setor.

Existe uma demanda por parte de alguns países por flores e plantas exóticas. $O$ Brasil possui condições para explorar este mercado e ocupar um lugar de destaque na floricultura mundial, já que por sua extensão geográfica, apresenta uma amplitude muito grande de clima e solo, favorecendo a implantação de uma floricultura diversificada e rica. Para isso, faz-se necessário a introdução de espécies mais resistentes às condições tropicais, o aprimoramento das técnicas de cultivo de espécies e a adequação cultural de outras.

\section{- Produtividade}

Prevalecerão no mercado os produtores de flores e plantas ornamentais especializados, ou seja, aqueles que investem em tecnologia de produção como o uso de estufas associadas à irrigação controlada, nebulização e fertirrigação, incorporando inclusive avançados processos em biotecnologia. 
Também deverão ocorrer transformações dos sistemas de distribuição atacadista, através da organização de plataformas operacionais e sistemas logísticos eficientes e ágeis, voltadas ao atendimento das modernas demandas e necessidades do consumidor.

\section{- Qualidade}

O mercado valorizará um modelo único de padronização (classificação do produto, embalagem, durabilidade, controle fitossanitário, etc) e a posterior certificação dos produtos. É imprescindível a existência de uma linguagem de qualidade e sua utilização como meio de comunicação na comercialização.

Também ocorrerá maior preocupação com o aprimoramento técnico-gerencial e profissional dos agentes envolvidos na cadeia - produtores e comerciantes/distribuidores atacadistas e varejistas.

\section{- Comercialização eletrônica}

As taxas brasileiras de crescimento da internet e do comércio eletrônico são as mais explosivas do mundo. O país já tem cerca de 5 milhões de usuários e perto de 250 servidores Web instalados. $\mathrm{O}$ índice de crescimento dessas atividades no pais é de impressionantes $117 \%$ ao ano.

No setor de flores e plantas ornamentais, o comércio eletrônico representa $0,5 \%$ das vendas. Estima-se que nos próximos 3 anos deverá ser 10 vezes maior (representando $5 \%$ das vendas).

Essa revolução digital alterará em muito os conceitos de espaço e tempo. Um sistema de distribuição atacadista de flores e plantas ornamentais não necessitará obrigatoriamente ocupar muito espaço; poderá até ser virtual e estar em qualquer lugar. Dados e mensagens poderão ser enviados e recebidos simultaneamente, em tempo real.

O mundo da alta tecnologia de informação - internet, software, harctware, rede por cabo e via satélite - conduzirá a uma era em que a compra e a venda serão mais 
automatizadas. As informações fluirão pelos sistemas de distribuição em um instante, com custo muito baixo. Os fornecedores identificarão compradores em potencial, e os compradores terão facilidades em identificar os melhores fornecedores e produtos. As distâncias e o tempo, grande barreira para os sistemas de distribuição atacadista, encolherão rapidamente.

Os administradores terão de repensar as bases dos processos pelos quais agregam valores ao consumidor. Necessitarão melhorar suas habilidades de gerenciamento, acompanhando como as "compras virtuais" estão mudando a maneira como as empresas comercializam produtos e serviços.

\section{- Sistemas de distribuição atacadista público "versus" privado}

A falta de credibilidade da administração pública junto à população, a ausência de políticas de investimentos e modernização, a desmotivação e a baixa de capacitação gerencial do servidor público se acentuarão ainda mais nos próximos anos, diminuindo as vantagens comparativas dos sistemas de distribuição atacadista público em relação ao privado.

No campo da alta tecnologia da informação, os sistemas de distribuição atacadista público encontrarão maiores obstáculos, principalmente os de ordem financeira e gerencial, para se modernizarem.

A tendência desses sistemas públicos - muitos dos quais já integram o Programa de Privatização do Estado - é transferir o controle acionário e operacional para grupos privados.

Em resumo, muitas das tendências apresentadas já estão acontecendo, somente os impactos é que ainda não se fizeram sentir nos diversos agentes da cadeia do agribusiness das flores e plantas ornamentais. A partir do domínio da alta tecnologia de informação, as empresas aumentaram infinitamente sua capacidade de transportar idéias e dados de forma rápida e barata. É necessário que os participantes do Sistema 
Agroindustrial das Flores e Plantas Ornamentais, principalmente os sistemas de distribuição atacadista, compreendam o mercado em rápida mudanças no qual trabalham.

\section{Considerações para futuros estudos}

Através da realização deste trabalho, observou-se que outras considerações sobre esta temática deverão ser analisadas em futuros trabalhos, como:

- Caracterização da distribuição de flores e plantas ornamentais nos principais países produtores e as principais tendências mundiais.

- Análise de outros sistemas de comercialização de flores e plantas ornamentais, dentre eles a venda direta do produtor para as grandes redes varejistas, sob a ótica da ECT, já que esse referencial teórico é bastante rico na análise organizacional.

- Análise dos impactos que ocorrerão na distribuição de flores e plantas ornamentais com a crescente introdução da comercialização eletrônica no Brasil.

- A eficiência também deverá ser avaliada pelos sistemas de distribuição atacadista comparando os valores obtidos neste trabalho com valores eficientes (ideal). Para isso, deverá fixar indicadores-chave eficientes (ideal), a partir dos dados históricos do próprio sistema de distribuição ou dos sistemas concorrentes, possibilitando aos gestores dos sistemas planejar metas e acompanhar o desempenho desejado. 


\section{REFERÊNCIAS BIBLIOGRÁFICAS}

AIMONE, T. How do United States statistics stack up?. Flora Culture International, p.30-32, nov. 1997.

AKI, A.Y. O Sistema Veiling na comercialização de hortifrutigranjeiros. Holambra, 1992. 80p.

AKI, A.Y. Repensando a comercialização de flores. Holambra,1998. 110p.

ALMEIDA, F.R.F.; AKI, A.Y. Grande crescimento no mercado das flores. Agroanalysis, v. 15, n.9, p.8-11, set. 1995.

ALSTON, L.J. A framework for understanding the new institutional economics. /Apresentado ao 1. Seminário Brasileiro sobre a Nova Economia Institucional, Universidade de São Paulo, São Paulo, 1998/

ARRUDA, S.T.; OLIVETTE, M.P.A.; CASTRO, C.E.F. Diagnóstico da floricultura do Estado de São Paulo. Revista Brasileira de Horticultura Ornamental, v.2, n.2, p.1-18, 1996.

AZEVEDO, P.F. Integração vertical e barganha. São Paulo, 1996. 219p. Tese (Doutorado) - Faculdade de Economia, Administração e Contabilidade Departamento de Economia, Universidade de São Paulo.

AZEVEDO, P.F. Organização industrial. In: PINHO, D.B.; VASCONCELOS, M.A.S.

(Org.) Manual de economia. São Paulo: Saraiva, 1998. cap. 8, p.195-222. 
BOLETIM MENSAL DA COMPANHIA DE ENTREPOSTOS E ARMAZÉNS GERAIS DE SÃo PAULO - CEAGESP. São Paulo, out.1999.

BONGERS, F.; MOTOS, J.R.; OLIVEIRA, M.J.G.; AKI, A. Avaliação sobre o mercado de flores. /Apresentado na reunião de avaliação sobre o mercado de flores, Holambra, 1999/

CARVALHO, L.C.P. de. Teoria da firma: a produção e a firma. In: PINHO, D.B.; VASCONCELOS, M.A.S. (Org.) Manual de economia. São Paulo: Saraiva, 1998. cap.6, p.144-180.

CASTRO, C.E.F.; ANGELIS, B.L.D.; MOURA, L.P.P. et al. Manual de floricultura. Maringá, 1992. 279p.

CLARO, D.P. Análise do complexo agroindustrial das flores do Brasil. Lavras, 1998. 103p. Dissertação (M.S) - Universidade Federal de Lavras.

COBRA, M. Administração de marketing. 2.ed. São Paulo: Atlas, 1992. cap.5, p.143-200: Inteligência de marketing e pesquisa de mercado.

DAVIS, J.H; GOLDBERG, R.A. A concept of agribusiness. Cambridge: Harvard University Press, 1957. p.85.

GÓES, V.L. de. A comercialização internacional de flores e a formação de preço. São Paulo, 1997. 143p. Dissertação (M.S) - Fundação Getúlio Vargas - Escola de Administração de Empresas de São Paulo.

GUTIERREZ, A.S.D. Linguagem comum. Agroanalysis, v. 19, p.43-48, jun. 1999. 
IEMMA, A.F. Estatística descritiva. Piracicaba: $\varphi \sigma \rho$ Publicações, 1992. 182p.

INSTITUTO BRASILEIRO DE FLORICULTURA. $1^{\circ}$ Encontro brasileiro de dirigentes de mercado de flores e plantas ornamentais. http://www.ceasacampinas.com.br/ibra.htm (18/04/99).

JANK, M.S. Competitividade do agribusiness brasileiro: discussão teórica e evidências no sistema carnes. São Paulo, 1996. 195p. Tese (Doutorado) - Faculdade de Economia, Administração e Contabilidade - Departamento de Administração, Universidade de São Paulo.

KAMPF, A.N. A floricultura brasileira em números. Revista Brasileira de Horticultura Ornamental, v.3, n. 1, p. 1-7, 1997.

KENNEDY, P.L.; HARRISON, R.W.; KALAITZANDONAKES, N.G. et al. Perspectives on evaluating competitiveness in agribusiness industries. Agribusiness, v.13, n.4, p.385-392, 1997.

KIYUNA, I. Flores. Prognóstico Agrícola, v.2, p. 189-194, 1998.

KOTLER, P; ARMSTRONG, G. Princípios de marketing. Rio de Janeiro: PrenticeHall do Brasil, 1993. 478p.

LAU, L.J; YOTOPOULOS, P.A. A test for relative efficiency and application to Indian agriculture. The American Economic Review, v.61, p.94- 109, Mar. 1971.

LIMA, R. Modernidade por atacado. Agroanalysis, v.19, p.39-42, jun. 1999. 
MACHADO FILHO, C.A.P. O mercado de animais no Brasil e a evolução do sistema de leilões. São Paulo, 1997. 150p. Dissertação (M.S.) - Faculdade de Economia, Administração e Contabilidade - Departamento de Administração, Universidade de São Paulo.

MARQUES, P.V; AGUIAR, D.R.D. Comercialização de produtos agricolas. São Paulo: EDUSP, 1993. cap.3, p.93-115: Estruturas de mercados agroindustriais.

MARTINELLI, S. Floricultura. Superhiper, v.24, n. 277, p.122-128, set. 1998.

MATTAR, F.N. Pesquisa de marketing. São Paulo: Atlas, 1996. 270p.

MEZZOMO, C.P.L. Sistema agroindustrial das olericolas congeladas: a coordenação entre o olericultor e a agroindústria do congelamento. Lavras, $1997.137 \mathrm{p}$. Dissertação (M.S.) - Universidade Federal de Lavras.

MORAES, M.A.F.D. A desregulamentação do setor sucroalcooleiro brasileiro. Piracicaba, 1999. 292p. Tese (Doutorado) - Escola Superior de Agricultura "Luiz de Queiroz", Universidade de São Paulo.

NEVES, M.F. Sistema agroindutrial citrícola: um exemplo de quase-integração no agribusiness brasileiro. São Paulo, 1995. 116p. Dissertação (M.S) - Faculdade de Economia, Administração e Contabilidade - Departamento de Administração, Universidade de São Paulo.

NEVES, M.F. Um modelo para planejamento de canais de distribuição no setor de alimentos. São Paulo, 1999. 297p. Tese (Doutorado) - Faculdade de Economia, Administração e Contabilidade - Departamento de Administração, Universidade de São Paulo. 
OHANIAN, N.K. Vertical Integration in the U.S. pulp and paper industry, 1900-1940. The Review of Economics and Statistics, v.76, n.1, p.202-207, Feb.1994.

RIBEIRO, A.R.B.M. Abastecimento de madeira para a produção de celulose: uma aplicação da economia dos custos de transação. Piracicaba, 1998. 117p. Dissertação (Mestrado) - Escola Superior de Agricultura "Luiz de Queiroz", Universidade de São Paulo.

RIBEIRO, B.A.M. Coordenação vertical do transporte de madeira: análise empírica dos arranjos institucionais existentes na indústria brasileira de celulose. Piracicaba, 1998. 113p. Dissertação (Mestrado) - Escola Superior de Agricultura "Luiz de Queiroz", Universidade de São Paulo.

RIGUETTI, M.A.; FUSCO, J.P.A. Indicadores de desempenho operacional em empresas fabricantes de pequeno e médio porte. In: SIMPÓSIO DE ADMINISTRAÇÃO DA PRODUÇÃO, LOGÍSTICA E OPERAÇÕES INDUSTRIAIS, 2., São Paulo, 1999. Anais. São Paulo: FGV, 1999. p. 304-316.

ROOYEN, S.R.V.; OPTIZ, R. Veiling - leilão eletrônico de flores da Holambra. Preços Agrícolas, n.127, p.24-26, maio 1997.

SAHELI, S.; MACEDO, P.B.R. Eficiência técnica das unidades federativas brasileiras padrões e determinantes. Economia Aplicada, v.2, n.4, p.647-679, 1998.

SAMARA, B.S.; BARROS, J.C. Pesquisa de marketing: conceitos e metodologia. São Paulo: Makron Books, 1994. 156p.

SCHEAFFER, R.L.; MENDENHALL, W.; OTT, L. Elementary survey sampling. 3.ed. Boston: Duxbury Press, 1986. 323p. 
SILVEIRA, A.C. Flores já movimentam R\$ 1,1 bilhão por ano. Gazeta Mercantil. Empresas \& Negócios, São Paulo, 4 set.1997. p.C-7.

- SMORIGO, J.N. Segmentação do mercado de mudas de crisântemo no Brasil. Piracicaba: USP. ESALQ. Depto. de Economia e Sociologia Rural, 1997. 81p.

SPÍNOLA, M.R.P.; TROSTER, R.L. Estruturas de mercado. In: PINHO, D.B.; VASCONCELOS, M.A.S. (Org.) Manual de economia. São Paulo: Saraiva, 1998. cap.7, p.181-194.

TULL, D.S.; HAWKINS, D.I. Marketing research: measurement \& method. 6.ed. New York: Macmillan, 1993. 863p.

TUPY, O.; TAMAGUCHI, L.C.T. Eficiência e produtividade: conceitos e medição. Agricultura em São Paulo, v.45, n.2, p.39-51, 1998.

VEILING-HOLAMBRA. Boletim Anual, 1997.

WESSELS, W.J. Economia. São Paulo: Saraiva, 1998. cap.1, p.1-17: De que trata a economia.

WILLIAMSON, O.E. The economics institution of capitalism. New York: The Free Press, 1985. 449p.

WILLIAMSON, O.E. The mechanisms of governance. New York: Oxford University Press, 1996. 429p. 
ZYLBERSZTAJN, D.; JANK, M.S.; KOOL, M.; SLUYS, T. Holanda: um modelo de agribusiness. São Paulo: PENSA/FIA/FEA/USP, 1992. 90p. (Relatório Grupo PENSA - USP)

ZYLBERSZTAJN, D. Estrutura de governança e coordenação do agribusiness: uma aplicação da nova economia das instituições. São Paulo, 1995. 238p. Tese (LivreDocência) - Faculdade de Economia, Administração e Contabilidade - Departamento de Administração, Universidade de São Paulo. 
APÊNDICES 


\section{APÊNDICE 1: TABELAS DE RESULTADOS}

Tabela 41. Faturamento dos sistemas de distribuição, 1997-1999 (em R\$).

\begin{tabular}{lcccc}
\hline Ano & SPT1 $^{1}$ & SPT2 $^{3}$ & SC & SPR $^{4}$ \\
\hline 1997 & 177.279 .546 & - & 79.000 .000 & - \\
1998 & 109.143 .438 & 50.000 .000 & 72.000 .000 & - \\
$1999^{2}$ & 124.993 .149 & 46.614 .643 & 60.818 .437 & 11.099 .000 \\
\hline
\end{tabular}

Fonte: Dados da pesquisa

${ }^{1}$ Valor estimado por Santos ${ }^{20}$. O valor oficial apresentado no Boletim Mensal da Companhia de Entrepostos e Armazéns Gerais de São Paulo - CEAGESP (1999) é calculado para alguns produtos e variedades.

${ }^{2}$ Faturamento acumulado de janeiro a outubro de 1999.

${ }^{3}$ O SPT2 não possui dados do faturamento de 1997.

${ }^{4}$ O SPR foi inaugurado em novembro de 1998.

Tabela 42. Dias de funcionamento dos sistemas de distribuição.

\begin{tabular}{lc}
\hline \multicolumn{1}{c}{ Sistema de distribuição } & Dias de funcionamento \\
\hline SPT1 & $\begin{array}{c}\text { MLP: terça e sextas-feiras } \\
\text { PBCF: segunda e quintas-feiras } \\
\text { Segundas e quintas-feiras }\end{array}$ \\
SPT2 & segunda às sextas-feiras \\
SC & segunda aos sábados ${ }^{22}$ \\
SPR & \\
\hline
\end{tabular}

Fonte: Dados da pesquisa

\footnotetext{
${ }^{20}$ SANTOS, A. C. (CEAGESP. Companhia de Entrepostos e Armazéns Gerais de São Paulo - Setor de Cotação de Preços. São Paulo). Comunicação Pessoal, 1999.

${ }^{21}$ O SPT2 funciona de segunda aos sábados, no entanto, o maior movimento ocorre às segundas e quintas-feiras.

${ }^{22} \mathrm{O}$ horário de funcionamento da FLORANET é de se segunda às sextas-feiras das 6:00 às 18:00 hrs e aos sábados das 6:00 às 12:00hrs.
} 
Tabela 43. Tempo gasto com a comercialização por dia e semana ${ }^{1}$.

\begin{tabular}{|c|c|c|}
\hline Sistema de distribuição & Tempo por dia & Tempo por semana \\
\hline SPT1 & $8 \mathrm{hrs} 30 \mathrm{~min}$ & $34 \mathrm{hrs}$ \\
\hline SPT2 & $6 \mathrm{hrs} 50 \mathrm{~min}$ & $13 \mathrm{hrs} 40 \mathrm{~min}$ \\
\hline SC & $12 \mathrm{hrs}$ & $60 \mathrm{hrs}$ \\
\hline SPR & $12 \mathrm{hrs}$ & $66 \mathrm{hrs}$ \\
\hline
\end{tabular}

Fonte: Dados da pesquisa

${ }^{1}$ O valor do tempo gasto para a comercialização no SPT1 e SPT2 é uma média da amostra estudada. Já no SC e SPR são valores médio do tempo gasto para a comercialização calculado pelos responsáveis pelo setor de logistica de cada sistema.

Tabela 44 Tempo gasto com a comercialização no período de janeiro a outubro de 1999.

\begin{tabular}{lc}
\hline Sistema de distribuição & Tempo no período \\
\hline SPT1 & $1.360 \mathrm{hrs}$ \\
SPT2 & $546 \mathrm{hrs} 40 \mathrm{~min}$ \\
SC & $2.400 \mathrm{hrs}$ \\
SPR & $2.640 \mathrm{hrs}$ \\
\hline
\end{tabular}

Fonte: Dados da pesquisa

Tabela 45. Número de homens envolvidos por dia de comercialização.

\begin{tabular}{lc}
\hline Sistema de distribuição & Número de homens \\
\hline SPT1 & $1341^{1}$ \\
SPT2 & $755^{2}$ \\
SC & 196 \\
SPR & 24 \\
\hline
\end{tabular}

Fonte: Dados da pesquisa

' Segundo dados da pesquisa, no SPT1 utiliza-se em média 2 homens por permissionário. No MLP existem 1.101 permissionários (2.202 homens) e na PBCF 240 permissionários (480 homens). Portanto, em 1 dia de comercialização, utilizam-se aproximadamente 1.341 homens.

${ }^{2}$ Segundo dados da pesquisa, no SPT2 utiliza-se em média 2,5 homens por permissionário (755 homens). 
Tabela 46. Tempo de trabalho por homem no período de um dia.

\begin{tabular}{lc}
\hline Sistema de distribuição & Tempo no periodo \\
\hline SPT1 & $8 \mathrm{hrs} 30 \mathrm{~min}$ \\
SPT2 & $6 \mathrm{hrs} 50 \mathrm{~min}$ \\
SC & $8 \mathrm{hrs}$ \\
SPR & $8 \mathrm{hrs}$ \\
\hline
\end{tabular}

Fonte: Dados da pesquisa

Tabela 47. Motivo de utilização do SPT1 pelos produtores.

\begin{tabular}{lccccc}
\hline Alternativa & $1 . p^{1}$ & $\begin{array}{c}\text { Peso } \\
2\end{array}$ & $2 . p$ & $\begin{array}{c}\text { Peso } \\
1\end{array}$ & Total \\
\hline Tradição & 15 & 30 & 13 & 13 & 43 \\
Localização & 11 & 22 & 11 & 11 & 33 \\
Falta de op̧̧ão & 12 & 24 & 8 & 8 & 32 \\
Demanda & 8 & 16 & 11 & 11 & 27 \\
Preço & 0 & 0 & 2 & 2 & 2 \\
Rapidez das vendas & 0 & 0 & 1 & 1 & 1 \\
Segurança & 0 & 0 & 0 & 0 & 0 \\
\hline Total & 46 & & 46 & \\
\hline
\end{tabular}

Fonte: Dados da pesquisa

${ }^{1}$ Tabulação utilizada para perguntas com ordem de preferência (tabulação ponderada). De acordo com Samara \& Barros (1994), as perguntas tabuladas de forma ponderada devem ter a análise qualitativa.

Tabela 48. Motivo de utilização do SPT2 pelos produtores.

\begin{tabular}{lccccc}
\hline Alternativa & $1 . p$ & $\begin{array}{c}\text { Peso } \\
2\end{array}$ & $2 . p$ & $\begin{array}{c}\text { Peso } \\
1\end{array}$ & Total \\
\hline Localização & 20 & 40 & 7 & 7 & 47 \\
Demanda & 9 & 18 & 15 & 15 & 33 \\
Tradição & 6 & 12 & 6 & 6 & 18 \\
Falta de opção & 3 & 6 & 8 & 8 & 14 \\
Preço & 4 & 8 & 2 & 2 & 10 \\
Rapidez das vendas & 0 & 0 & 1 & 1 & 1 \\
Segurança & 0 & 0 & 3 & 3 & 3 \\
\hline Total & 42 & & 42 & \\
\hline
\end{tabular}

Fonte: Dados da pesquisa 
Tabela 49. Motivo de utilização do SC pelos produtores.

\begin{tabular}{lccccc}
\hline Alternativa & $1 . p$ & $\begin{array}{c}\text { Peso } \\
2\end{array}$ & $2 . p$ & $\begin{array}{c}\text { Peso } \\
1\end{array}$ & Total \\
\hline Segurança & 15 & 30 & 14 & 14 & 44 \\
Rapidez das vendas & 10 & 20 & 6 & 6 & 26 \\
Localização & 4 & 8 & 6 & 6 & 14 \\
Preço & 1 & 2 & 2 & 2 & 4 \\
Tradição & 1 & 2 & 0 & 0 & 2 \\
Demanda & 0 & 0 & 2 & 2 & 2 \\
Falta de opção & 0 & 0 & 1 & 1 & 1 \\
\hline Total & 31 & 31 & & \\
\hline
\end{tabular}

Fonte: Dados da pesquisa

Tabela 50. Motivo de utilização do SPR pelos produtores.

\begin{tabular}{lccccc}
\hline Alternativa & $1 . p$ & $\begin{array}{c}\text { Peso } \\
2\end{array}$ & $2 . p$ & Peso & Total \\
\hline Rapidez das vendas & 1 & 2 & 1 & 1 & 3 \\
Demanda & 1 & 2 & 0 & 0 & 2 \\
Localização & 1 & 2 & 0 & 0 & 2 \\
Preço & 0 & 0 & 1 & 1 & 1 \\
Falta de opção & 0 & 0 & 1 & 1 & 1 \\
Tradição & 0 & 0 & 0 & 0 & 0 \\
Segurança & 0 & 0 & 0 & 0 & 0 \\
Não respondeu & 1 & 2 & 1 & 1 & 3 \\
\hline Total & 4 & 4 & \\
\hline
\end{tabular}

Fonte: Dados da pesquisa

Tabela 51. Vantagem avaliada pelos produtores em utilizar o SPT1.

\begin{tabular}{|c|c|c|}
\hline Alternativa & $f$ & $\%^{2}$ \\
\hline Demanda & 16 & 34,8 \\
\hline Nenhuma vantagem & 15 & 32,6 \\
\hline Recebimento à vista & 8 & 17,4 \\
\hline Localização & 8 & 17,4 \\
\hline Outros & 9 & 19,6 \\
\hline Total de respostas ${ }^{1}$ & 56 & 121,8 \\
\hline Total de entrevistas & 46 & 100,0 \\
\hline
\end{tabular}

Fonte: Dados da pesquisa

${ }^{1}$ Média de respostas por entrevistados $=1,2$.

${ }^{2} \mathrm{~A}$ porcentagem das alternativas é feita tendo por base o total de respostas. 
Tabela 52. Vantagem avaliada pelos produtores em utilizar o SPT2.

\begin{tabular}{lcc}
\hline Alternativa & $f$ & $\%^{2}$ \\
\hline Localização & 8 & 19,0 \\
Cadastro de consumidores & 7 & 16,7 \\
Horário de funcionamento & 7 & 16,7 \\
Infra-estrutura & 6 & 14,3 \\
Segurança & 5 & 11,9 \\
Demanda & 5 & 11,9 \\
Outros & 11 & 26,2 \\
\hline Total de respostas ${ }^{1}$ & 49 & 116,7 \\
Total de entrevistas & 42 & 100,0 \\
\hline
\end{tabular}

Fonte: Dados da pesquisa

${ }^{1}$ Média de respostas por entrevistados $=1,2$.

${ }^{2}$ A porcentagem das alternativas é feita tendo por base o total de respostas.

Tabela 53. Vantagem avaliada pelos produtores em utilizar o SC.

\begin{tabular}{lcc}
\hline Alternativa & $f$ & $\%^{2}$ \\
\hline Segurança & 30 & 96,8 \\
Transparência na formação do preço & 8 & 25,8 \\
Rapidez nas vendas & 4 & 12,9 \\
Qualidade do produto oferecido & 3 & 9,7 \\
Outros & 7 & 22,6 \\
\hline Total de respostas ${ }^{1}$ & 52 & 167,8 \\
Total de entrevistas & 31 & 100,0 \\
\hline
\end{tabular}

Fonte: Dados da pesquisa

${ }^{1}$ Média de respostas por entrevistados $=1,7$.

${ }^{2}$ A porcentagem das altemativas é feita tendo por base o total de respostas.

Tabela 54. Vantagem avaliada pelos produtores em utilizar o SPR.

\begin{tabular}{lll}
\hline Alternativa & $f$ & $\%^{2}$ \\
\hline Rapidez nas vendas & 1 & 25,0 \\
Sistema confiável & 1 & 25,0 \\
Não respondeu & 2 & 50,0 \\
\hline Total de respostas ${ }^{1}$ & 4 & 100,0 \\
Total de entrevistas & 4 & 100,0 \\
\hline
\end{tabular}

Fonte: Dados da pesquisa

${ }^{1}$ Média de respostas por entrevistados $=1,0$.

${ }^{2}$ A porcentagem das alternativas é feita tendo por base o total de respostas. 
Tabela 55. Desvantagem avaliada pelos produtores em utilizar o SPT1.

\begin{tabular}{lcc}
\hline Alternativa & $f$ & $\%^{2}$ \\
\hline Horário de funcionamento & 19 & 41,3 \\
Falta de segurança & 12 & 26,1 \\
Desorganização administrativa & 8 & 17,4 \\
Carregadores & 5 & 10,9 \\
Nenhuma & 4 & 8,7 \\
Mistura de consumidores & 3 & 6,5 \\
Inadimplência $^{\text {Outros }}{ }^{3}$ & 3 & 6,5 \\
Total de respostas $^{1}$ & 16 & 34,8 \\
Total de entrevistas $^{1}$ & 70 & 152,2 \\
\hline
\end{tabular}

Fonte: Dados da pesquisa

${ }^{1}$ Média de respostas por entrevistados $=1,5$.

${ }^{2}$ A porcentagem das alternativas é feita tendo por base o total de respostas.

${ }^{3}$ Só é permitido aos consumidores utilizar os carregadores que estão cadastrados no SPT1.

Tabela 56. Desvantagem avaliada pelos produtores em utilizar o SPT2.

\begin{tabular}{|c|c|c|}
\hline Alternativa & $f$ & $\%^{2}$ \\
\hline Excesso de taxas & 21 & 50,0 \\
\hline Estrutura inadequada ${ }^{3}$ & 17 & 40,5 \\
\hline Forma de pagamento dos consumidores ${ }^{4}$ & 5 & 11,9 \\
\hline Desorganização administrativa & 4 & 9,5 \\
\hline Falta de segurança & 3 & 7,1 \\
\hline Horário de entrada de consumidores ${ }^{5}$ & 3 & 7,1 \\
\hline Outros & 8 & 19,0 \\
\hline Total de respostas ${ }^{1}$ & 61 & 145.1 \\
\hline Total de entrevistas & 42 & 100,0 \\
\hline
\end{tabular}

Fonte: Dados da pesquisa

${ }^{1}$ Média de respostas por entrevistados $=1,5$.

${ }^{2}$ A porcentagem das altemativas é feita tendo por base o total de respostas.

${ }^{3}$ Estrutura inadequada, como falta de estacionamento e local muito quente.

${ }^{4}$ Forma de pagamento dos consumidores é muito variável e o prazo é muito longo.

${ }^{5}$ Os produtores chegam ao sistema às 6:00 e os consumidores só podem entrar à partir das 8:00. 
Tabela 57. Desvantagem avaliada pelos produtores em utilizar o SC.

\begin{tabular}{|c|c|c|}
\hline Alternativa & $f$ & $\%^{2}$ \\
\hline Nenhuma & 17 & 54,8 \\
\hline Lixo $^{3}$ & 3 & 9,7 \\
\hline Excesso de taxação & 2 & 6,5 \\
\hline Exclusividade na entrega da produção ${ }^{4}$ & 2 & 6,5 \\
\hline Falta de contato com o consumidor & 2 & 6,5 \\
\hline Outros & 5 & 16,1 \\
\hline Total de respostas ${ }^{1}$ & 31 & 110,1 \\
\hline Total de entrevistas & 31 & 100 \\
\hline
\end{tabular}

Fonte: Dados da pesquisa

${ }^{1}$ Média de respostas por entrevistados $=1,0$.

${ }^{2}$ A porcentagem das alternativas é feita tendo por base o total de respostas.

${ }^{3}$ Quando um lote não atinge um preço mínimo, esse é destruído publicamente.

${ }^{4} \mathrm{O}$ produtor deve entregar sua produção exclusivamente no $\mathrm{SC}$.

Tabela 58. Desvantagem avaliada pelos produtores em utilizar o SPR.

\begin{tabular}{lcc}
\hline Alternativa & $f$ & $\%^{2}$ \\
\hline Sistema novo & 1 & 25,0 \\
Nenhuma & 3 & 75,0 \\
\hline \hline Total de respostas $^{1}$ & 4 & 100,0 \\
Total de entrevistas $^{2}$ & 4 & 100,0 \\
\hline
\end{tabular}

Fonte: Dados da pesquisa

${ }^{1}$ Média de respostas por entrevistados $=1,0$.

${ }^{2}$ A porcentagem das altemativas é feita tendo por base o total de respostas.

Tabela 59. Motivo de utilização do SPT1 pelos consumidores.

\begin{tabular}{lccccccc}
\hline Alternativa & $1 . p$ & $\begin{array}{c}\text { Peso } \\
\text { Localização }\end{array}$ & $2 . p$ & $\begin{array}{c}\text { Peso } \\
2\end{array}$ & $3 . p$ & Peso & Total \\
Variedades oferecidas & 26 & 78 & 7 & 14 & 4 & 4 & 96 \\
Tradição & 5 & 15 & 14 & 28 & 11 & 11 & 54 \\
Falta de opção & 7 & 21 & 10 & 20 & 8 & 8 & 49 \\
Prȩ̧o & 6 & 18 & 8 & 16 & 10 & 10 & 44 \\
Garantia de qualidade & 1 & 3 & 5 & 10 & 9 & 9 & 22 \\
Segurança & 0 & 0 & 2 & 4 & 3 & 3 & 7 \\
\hline Total & 1 & 3 & 0 & 0 & 1 & 1 & 4 \\
\hline
\end{tabular}

Fonte: Dados da pesquisa 
Tabela 60. Motivo de utilização do SPT2 pelos consumidores.

\begin{tabular}{lccccccc}
\hline Alternativa & $1 . p$ & $\begin{array}{c}\text { Peso } \\
\text { Localização }\end{array}$ & $2 . p$ & $\begin{array}{c}\text { Peso } \\
2\end{array}$ & $3 . p$ & Peso & Total \\
Variedades oferecidas & 23 & 69 & 8 & 16 & 5 & 5 & 90 \\
Tradição & 5 & 15 & 11 & 22 & 7 & 7 & 44 \\
Preço & 2 & 6 & 9 & 18 & 2 & 2 & 26 \\
Falta de opção & 5 & 15 & 3 & 6 & 4 & 4 & 25 \\
Garantia de qualidade & 3 & 9 & 3 & 6 & 4 & 4 & 19 \\
Segurança & 2 & 6 & 1 & 2 & 10 & 10 & 18 \\
Não respondeu & 1 & 3 & 6 & 12 & 2 & 2 & 17 \\
\hline Total & 0 & 0 & 0 & 0 & 7 & 7 & 7 \\
\hline
\end{tabular}

Fonte: Dados da pesquisa

Tabela 61. Motivo de utilização do SC pelos consumidores.

\begin{tabular}{lccccccc}
\hline Alternativa & $1 . p$ & $\begin{array}{c}\text { Peso } \\
3\end{array}$ & $2 . p$ & $\begin{array}{c}\text { Peso } \\
2\end{array}$ & $3 . p$ & $\begin{array}{c}\text { Peso } \\
1\end{array}$ & Total \\
\hline Preço & 16 & 48 & 1 & 2 & 6 & 6 & 56 \\
Garantia de qualidade & 6 & 18 & 12 & 24 & 7 & 7 & 49 \\
Variedades oferecidas & 4 & 12 & 9 & 18 & 9 & 9 & 39 \\
Segurança & 4 & 12 & 7 & 14 & 5 & 5 & 31 \\
Localização & 5 & 15 & 5 & 10 & 5 & 5 & 30 \\
Tradição & 2 & 6 & 2 & 4 & 5 & 5 & 15 \\
Falta de opção & 0 & 0 & 1 & 2 & 0 & 0 & 2 \\
\hline \hline Total & 37 & \multicolumn{3}{c}{37} & & \\
\hline
\end{tabular}

Fonte: Dados da pesquisa

Tabela 62. Motivo de utilização do SPR pelos consumidores.

\begin{tabular}{lccccccc}
\hline Alternativa & $1 . p$ & $\begin{array}{c}\text { Peso } \\
3\end{array}$ & $2 . p$ & $\begin{array}{c}\text { Peso } \\
2\end{array}$ & $3 . p$ & Peso & Total \\
\hline Garantia de qualidade & 6 & 18 & 8 & 16 & 3 & 3 & 37 \\
Localização & 3 & 9 & 4 & 8 & 2 & 2 & 19 \\
Segurança & 3 & 9 & 3 & 6 & 3 & 3 & 18 \\
Variedades oferecidas & 3 & 9 & 2 & 4 & 4 & 4 & 17 \\
Preço & 4 & 12 & 1 & 2 & 1 & 1 & 15 \\
Tradição & 0 & 0 & 1 & 2 & 6 & 6 & 8 \\
Falta de opcão & 0 & 0 & 0 & 0 & 0 & 0 & 0 \\
\hline Total & 19 & & 19 & \multicolumn{1}{c}{19} & & \\
\hline
\end{tabular}

Fonte: Dados da pesquisa 
Tabela 63. Outros problemas apresentados no sistema de distribuição - consumidor SPT1.

\begin{tabular}{lcc}
\hline Alternativa & $f$ & $\%^{2}$ \\
\hline Outros $^{3}$ & 22 & 47,8 \\
Horário de funcionamento & 8 & 17,4 \\
Falta de segurança & 5 & 10,9 \\
Preço elevado dos produtos & 3 & 6,5 \\
Nenhum problema & 3 & 6,5 \\
Dificuldade em encontrar o produto & 2 & 4,3 \\
Demora na entrega do produto & 1 & 2,2 \\
Falta de padronização dos produtos & 1 & 2,2 \\
Elevada taxa administrativa & 1 & 2,2 \\
Localização & 1 & 2,2 \\
\hline Total de respostas & 1 & 102,2 \\
Total de entrevistas & 47 & 100,0 \\
\hline
\end{tabular}

Fonte: Dados da pesquisa

${ }^{1}$ Média de respostas por entrevistados $=1,02$.

${ }^{2}$ A porcentagem das alternativas é feita tendo por base o total de respostas.

${ }^{3}$ Frequiência conjunta de consumidores, como varejistas, atacadistas e consumidor final, que pagam o mesmo preço pelos produtos e a falta de um estacionamento organizado e com mais espaço. 
Tabela 64. Outros problemas apresentados no sistema de distribuição - consumidor SPT2.

\begin{tabular}{lcc}
\hline Alternativa & $f$ & $\%^{2}$ \\
\hline Horário de funcionamento & 19 & 46,3 \\
Outros $^{3}$ & 14 & 34,1 \\
Nenhum problema & 3 & 7,3 \\
Falta de padronização dos produtos & 2 & 4,9 \\
Falta de segurança & 2 & 4,9 \\
Dificuldade em encontrar o produto & 2 & 4,9 \\
Demora na entrega do produto & 1 & 2,4 \\
Elevada taxa administrativa & 0 & 0,0 \\
Localização & 0 & 0,0 \\
Preço elevado dos produtos & 0 & 0,0 \\
\hline Total de respostas & 1 & 104.8 \\
Total de entrevistas & 43 & 100,0 \\
\hline
\end{tabular}

Fonte: Dados da pesquisa

${ }^{1}$ Média de respostas por entrevistados $=1,04$.

${ }^{2}$ A porcentagem das alternativas é feita tendo por base o total de respostas.

${ }^{3}$ Falta de um estacionamento organizado e com mais espaço, inexistência de um local adequado para o carregamento e mistura de consumidores (atacadistas e varejistas) que pagam o mesmo preço pelos produtos.

Tabela 65. Outros problemas apresentados no sistema de distribuição - consumidor SC.

\begin{tabular}{lcc}
\hline Alternativa & $f$ & $\%^{2}$ \\
\hline Nenhum problema & 14 & 37,8 \\
Outros ${ }^{3}$ & 12 & 32,4 \\
Demora na entrega do produto & 4 & 10,8 \\
Elevada taxa administrativa & 4 & 10,8 \\
Dificuldade em encontrar o produto & 4 & 10,8 \\
Horário de funcionamento & 0 & 0,0 \\
Falta de segurança & 0 & 0,0 \\
Localização & 0 & 0,0 \\
Falta de padronização dos produtos & 0 & 0,0 \\
Preço elevado dos produtos & 0 & 0,0 \\
\hline Total de respostas (1) & 38 & 102,6 \\
Total de entrevistas (2) & 37 & 100,0 \\
\hline
\end{tabular}

Fonte: Dados da pesquisa

${ }^{1}$ Média de respostas por entrevistados $=1,03$.

${ }^{2}$ A porcentagem das alternativas é feita tendo por base o total de respostas.

${ }^{3}$ Pouco prazo de pagamento e juros alto. 
Tabela 66. Outros problemas apresentados no sistema de distribuição - consumidor SPR.

\begin{tabular}{|c|c|c|}
\hline Alternativa & $f$ & $\%^{2}$ \\
\hline Nenhum problema & 10 & 52,6 \\
\hline Dificuldade em encontrar o produto ${ }^{3}$ & 8 & 42,1 \\
\hline Localização & 1 & 5,3 \\
\hline Demora na entrega do produto & 0 & 0,0 \\
\hline Falta de padronização dos produtos & 0 & 0,0 \\
\hline Elevada taxa administrativa & 0 & 0,0 \\
\hline Falta de segurança & 0 & 0,0 \\
\hline Horário de funcionamento & 0 & 0,0 \\
\hline Preço elevado dos produtos & 0 & 0,0 \\
\hline Outros & 0 & 0,0 \\
\hline Total de respostas $(1)^{1}$ & 19 & 100,0 \\
\hline Total de entrevistas (2) & 19 & 100,0 \\
\hline
\end{tabular}

Fonte: Dados da pesquisa

${ }^{1}$ Média de respostas por entrevistados $=1,1$.

${ }^{2}$ A porcentagem das alternativas é feita tendo por base o total de respostas.

${ }^{3}$ Quantidade restrita de produtos e variedades oferecidos pelo sistema de distribuição.

Tabela 67. Resultados de algumas análises estatísticas relativas as questões com variáveis quantitativas.

\begin{tabular}{|c|c|c|c|c|c|c|}
\hline \multirow{3}{*}{ Parâmetros } & \multicolumn{6}{|c|}{ Questão } \\
\hline & \multicolumn{2}{|c|}{$\ldots-\ldots$} & \multicolumn{2}{|c|}{$\ldots$ P3 -... } & \multicolumn{2}{|c|}{-..- P4 -...- } \\
\hline & $\mathrm{SPT}^{1}{ }^{1}$ & SPT2 & SPT1 & SPT2 & SPT1 & SPT2 \\
\hline Média & 8,37 & 6,79 & 1,83 & 2,52 & 4,54 & 4,00 \\
\hline Desvio-Padrão & 1,62 & 1,52 & 0,88 & 1,02 & 1,66 & 1,47 \\
\hline Variância & 2,64 & 2,32 & 0,77 & 1,04 & 2,74 & 2,15 \\
\hline
\end{tabular}

Fonte: Dados da pesquisa

${ }^{1}$ Esses resultados foram calculados para o SPT1 e SPT2 através da amostra de produtores entrevistados. Para o SC e SPR o valor de cada questão foi fomecido pelo responsável do setor de logística, pois a comercialização é intermediada por esses sistemas de distribuição e não pelos produtores, como ocorre no SPT1 e SPT2. Como não se trata de um valor estimado para uma amostra de produtores, não existem dados sobre média, desvio-padrão e variância. 


\title{
APÊNDICE 2: QUESTIONÁRIO DE PESQUISA
}

\section{A) PRODUTOR (P)}

\author{
Universidade de São Paulo \\ Escola Superior de Agricultura "Luiz de Queiroz" \\ Departamento de Economia, Administração e Sociologia
}

Nome do produtor:

Local da propriedade:

Data da entrevista:

1) Qual o sistema de distribuição utilizado?
( ) Veiling Holambra
( ) CEAGESP
( ) CEASA/Campinas
( ) FLORANET

2) * Quantas horas são necessárias para a comercialização no período de um dia?

3) * Número de homens envolvidos nesse período?

4) * Quanto tempo trabalha cada homem envolvido na comercialização nesse período?

5) * Quantas vezes você manuseia seu produto desde o descarregamento até o carregamento pelo cliente?
( ) Nenhuma vez
( ) 3 vezes
( ) 1 vez
( ) Mais de 3 vezes
( ) 2 vezes

6) * Que tipo de estrutura existe no sistema de distribuição para manter a qualidade do produto?

\footnotetext{
"Questões aplicadas aos produtores que distribuem via CEAGESP e CEASA/Campinas. No Veiling e FLORANET será aplicado ao responsável pelo setor de logistica.
} 
7) Por que utiliza esse sistema de distribuição?

(escolher 2 altemativas por ordem de preferência)
( ) Localização
( ) Tradição
( ) Segurança
( ) Preço
( ) Demanda
( ) Falta de opção
( ) Rapidez das vendas

8) Quais as vantagens e desvantagens de utilizar esse sistema de distribuição? vantagens:

desvantagens:

9) Quem é o responsável pela assistência técnica na sua produção?
( ) Engenheiro Agrônomo
( )Fornecedores de insumos
( ) Técnico Agricola
( ) Próprio produtor

10) Existe treinamento especializado para os funcionários de acordo com a espécie de flores e plantas omamentais produzidas? Em caso afirmativo, como é realizado esse treinamento.

( ) Não

( ) Sim.

11) Os funcionários são de fácil substituição?

( ) Não

( ) $\operatorname{Sim}$

12) Utiliza sistema coberto de produção? Em caso afirmativo, de que tipo (sob cobertura, estufa climatizada, etc)?

( ) Não

( ) Sim.

13) As mudas ou sementes são:

( ) Produção própria

( ) Compradas de empresas especializadas 
14) Possui caminhão refrigerado para o transporte do produto?

( ) $\mathrm{Sim}$

( ) Não

15) Investe na marca de seu produto? Em caso afirmativo, de que forma?

( ) Não

( ) Sim.

16) Com que freqüência ocorre as vendas de flores e plantas ornamentais para o sistema de distribuição?
( ) Uma vez por semana
( ) 4 ou 5 dias por semana
( ) 2 ou 3 dias por semana
( ) 6 ou 7 dias por semana

17) Como faz o controle de pragas e doenças?

( ) Seqüencial. Com que freqüência?

( ) Conforme a necessidade

18) Qual é o maior risco associado à sua produção?
( ) Padronização
( ) Pragas e doenças
( ) Todos
( ) Clima
( ) Aquisição de insumos
( ) Nenhum

19) Qual é o maior risco associado à venda de seu produto?
( ) Inadimplência
( ) Preço
( ) Nenhum
( ) Demanda instável
( ) Todos

\section{B) SISTEMA DE DISTRIBUIÇÃO (SD)}

1) Qual é o tamanho da estrutura de comercialização $\left(\mathrm{m}^{2}\right)$ ? 
2) Qual foi o faturamento anual desde 1997 até 1999 ( no ano de 1999 o valor acumulado de janeiro a outubro)?

\section{C) CONSUMIDOR (C)}

Data da entrevista:

Sistema de distribuição:

1) O Sr. esta satisfeito com a qualidade do produto oferecido por este sistema de distribuição?

( ) Muito satisfeito

( ) Satisfeito

( ) Insatisfeito

( ) Muito insatisfeito

2) O preço pago pelo produto é coerente com a sua qualidade?

( ) $\operatorname{Sim}$ ( ) Não. Por que.

3) Por que utiliza esse sistema de distribuição? (escolher até 3 altemativas por ordem de preferência)
( ) Preço
( ) Tradição

( ) Segurança

( ) Localização

( ) Variedades oferecidas

( ) Falta de opção

( ) Garantia de qualidade

4) ${ }^{* *}$ Quanto tempo gasta para o carregamento?
( ) Nenhum
( ) 31 a $60 \mathrm{~min}$

( ) 1 a $15 \mathrm{~min}$.

( ) + de $60 \mathrm{~min}$.

( ) 16 a $30 \mathrm{~min}$.

" Questão para clientes atacadista. 
5) Qual o maior problema apresentado por este sistema de distribuição?
( ) Demora na entrega
( ) Dificuldade em encontrar o produto
( ) Falta de padronização dos produtos
( ) Horário de funcionamento
( ) Elevada taxa administrativa
( ) Localização
( ) Segurança
( ) Preço elevado dos produtos
( ) Nenhum
( ) Outros 